\title{
DEEP-SEA ANEMONES \\ (CNIDARIA: ANTHOZOA: ACTINIARIA) \\ FROM THE SOUTH ATLANTIC
}

LUCIANA C. GUSMÃO AND ESTEFANÍA RODRÍGUEZ

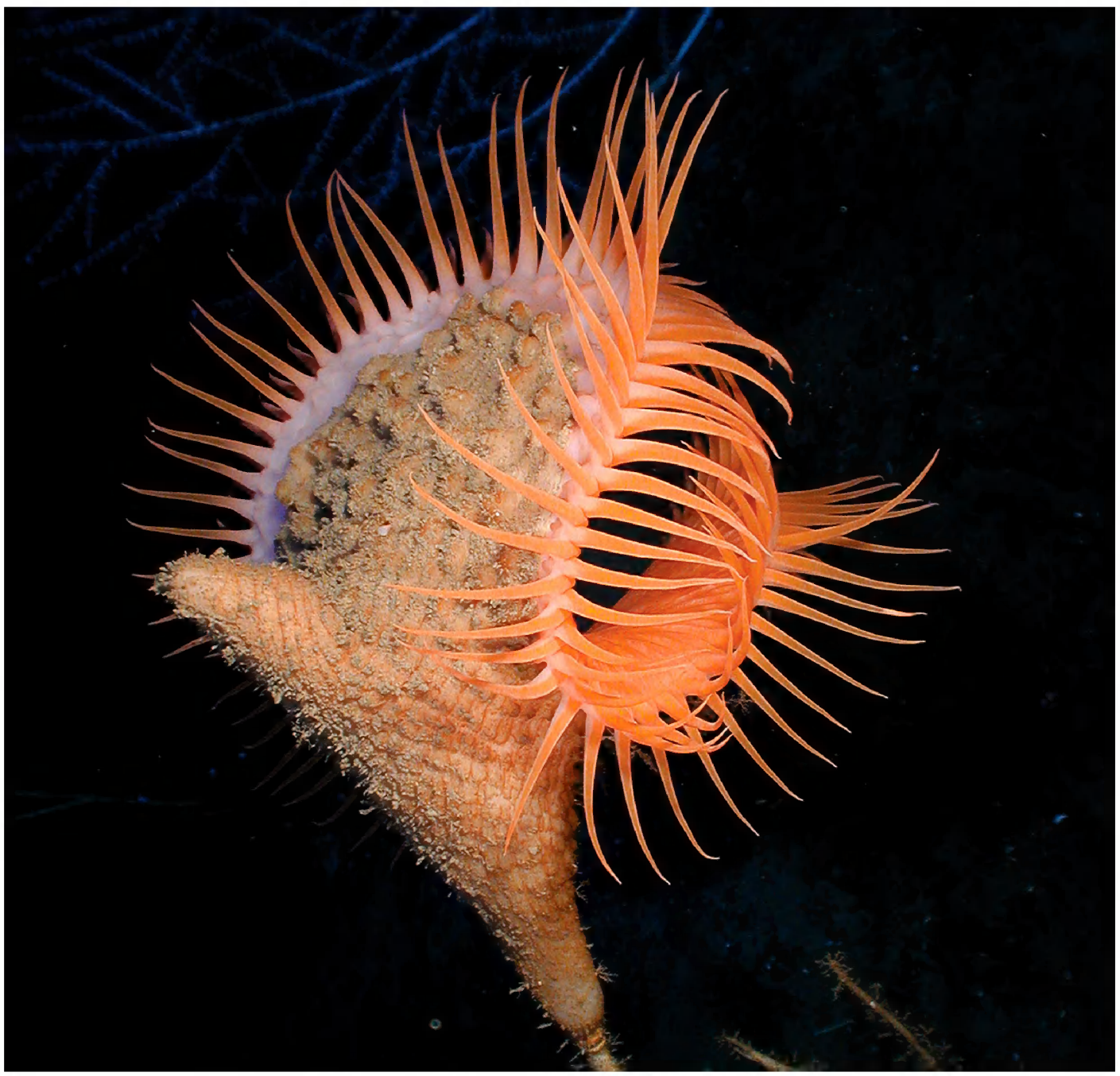

BULLETIN OF THE AMERICAN MUSEUM OF NATURAL HISTORY 


\title{
DEEP-SEA ANEMONES \\ (CNIDARIA: ANTHOZOA: ACTINIARIA) FROM THE SOUTH ATLANTIC
}

\author{
LUCIANA C. GUSMÃO \\ Division of Invertebrate Zoology \\ American Museum of Natural History \\ ESTEFANÍA RODRÍGUEZ \\ Division of Invertebrate Zoology \\ American Museum of Natural History
}

BULLETIN OF THE AMERICAN MUSEUM OF NATURAL HISTORY

Number 444, 69 pp., 22 figures, 12 tables

Issued February 4, 2021 


\section{CONTENTS}

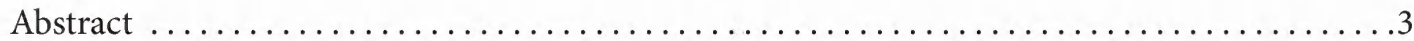

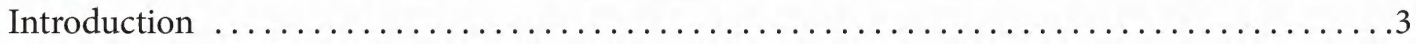

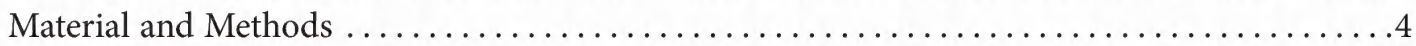

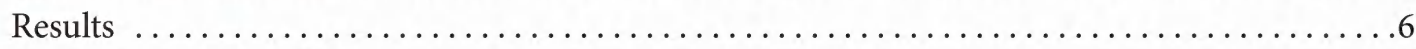

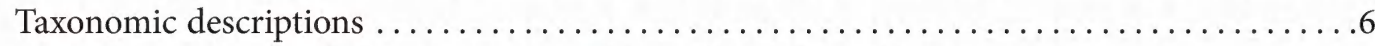

Actinernus mercedae Gusmão, López-González, and Rodríguez, sp. nov.. . . . . . . . .6

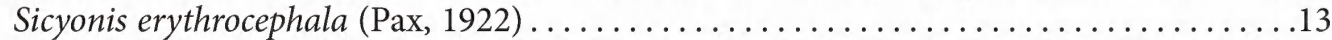

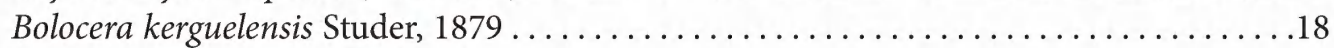

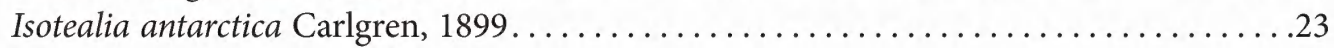

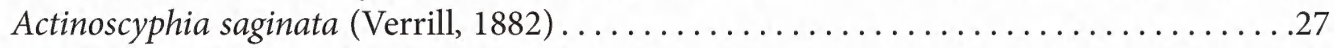

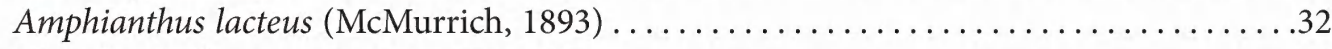

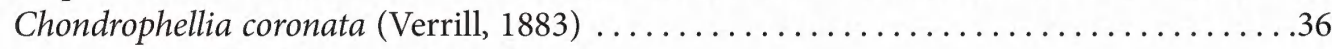

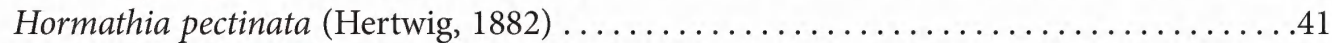

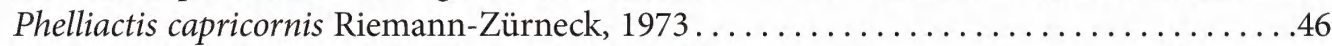

Phelliactis pelophila Riemann-Zürneck, 1973. . . . . . . . . . . . . . . . . . . . . . . . .49

Key to the deep-sea species of anemones off the coast of Brazil $\ldots \ldots \ldots \ldots \ldots \ldots \ldots$

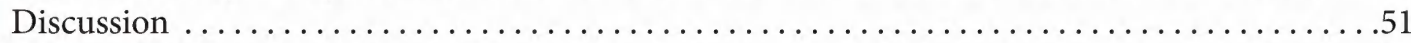

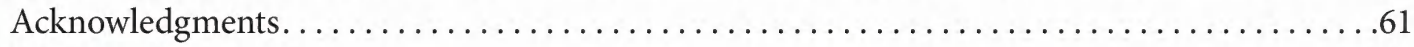

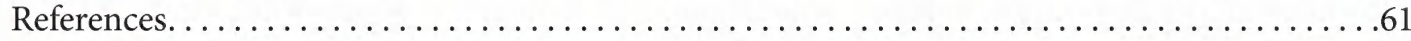




\begin{abstract}
Brazil has the longest coastline in South America with more than $7491 \mathrm{~km}$ of hydrologically and topologically complex continental margin. Despite its extensive coast, the sea anemone fauna of the country is sparsely known with only 54 species recorded. Difficulties of accessing Brazil's highly diversified coast and the historical small number of dredging expeditions and sea anemone taxonomists have contributed to the limited knowledge of its sea anemone diversity particularly in deep waters. Most species recorded from Brazil correspond to large, conspicuous intertidal species and only five species have been recorded from depths greater than $200 \mathrm{~m}$ : two small burrowing edwardsiids and three hormathiids from the southern coast of Brazil. Here, we provide complete descriptions, images of external and internal anatomy, microanatomy, cnidae, and geographic distribution for 10 species, six off the coast of Brazil and four from the southern portion of the Mid-Atlantic Ridge, one of which is also present in the Southern Ocean. Four of the six species found in Brazil represent new records of geographically widespread species for the country and the remaining two endemic species have their geographic and bathymetric ranges significantly extended northward. As a result, the number of species known for the Brazilian coast is raised to 63 species, 14 of which are known from the deep sea. We also recorded four deep-sea species in the south Mid-Atlantic Ridge (SMAR), including Actinernus mercedae, sp. nov., and two new records for the South Atlantic. We found that the deep-sea fauna of Brazil shares two deep-sea species with Argentina and two with the North Atlantic. Thus, La Plata River acts as a filter for shallow water species between Brazil and Argentina but is less effective for deep-sea anemones. The diversity of sea anemones recorded for SMAR shows similarities to the southwestern Atlantic and Southern Ocean. Finally, our finding of representatives of Bolocera in the SMAR and Actinoscyphia off the Brazilian coast suggests that they are bipolar genera with tropical emergence.
\end{abstract}

\section{INTRODUCTION}

The South Atlantic is bordered on the west by more than 13,000 km spanning the coastlines of Brazil, Uruguay, and Argentina. Brazil has the longest coastline in the continent with more than $7491 \mathrm{~km}$ of hydrologically and topologically complex continental margin comprising diverse but poorly known benthic ecosystems in the southwestern Atlantic (SWA; Miloslavich et al., 2011). The Brazilian continental margin is influenced by freshwater and sediment discharge from two major rivers (Amazon, La Plata) and by the warm Brazilian Current flowing southward and the cold Malvinas Current flowing northward (Prates et al., 2007). Areas of the Brazilian coast as well as offshore deep-sea habitats remain scarcely known (Turra et al., 2016). Deep-sea exploration in Brazil is relatively recent (since $~ 1986$ ) and has focused on fishes, macroinvertebrates, and zooplankton on coastal and midshelf waters, leaving benthic communities beyond the shelf break relatively unexplored (Miloslavich et al., 2011; Turra et al., 2016).

Compared with the North Atlantic, the deepsea benthos of the Equatorial Atlantic, and particularly the South Atlantic, is rather poorly known (Levin and Gooday, 2003). The deep central South Atlantic is one of the least studied areas of the world oceans with records of deepwater macrofauna diversity largely concentrated on the South American and African continental margins and the Southern Ocean (Perez et al., 2012). Despite being the most prominent ocean feature of the South Atlantic, knowledge about the MidAtlantic Ridge-with more than $14,000 \mathrm{~km}$, extending from Iceland $\left(87^{\circ} \mathrm{N}\right)$ to Bouvet Island $\left(54^{\circ} \mathrm{S}\right.$ ) and rising $2000-3000 \mathrm{~m}$ above the seafloor-derives from large-scale expeditions conducted by North Atlantic countries in the late 19th century, including the Challenger (Wüst, 1964). Because of the fragmented and unequal sampling effort along the total extent of the South Atlantic, patterns of diversity and distribution of taxa are 
not always clear (Turra et al., 2016), making comparisons within the South Atlantic and across the various Atlantic regions difficult.

Most species of sea anemones recorded in Brazil correspond to common, large polyps collected from shallow waters (Beneti et al., 2015), with deep-sea anemones recorded only sporadically from material collected in transit to other target areas (e.g., Challenger Expedition: Hertwig, 1882, 1888; Albatross Expedition: McMurrich, 1893) or during short excursions during investigations in neighboring regions (Terra Nova Expedition: Stephenson, 1918a) (Riemann-Zürneck, 1973). As a result, the number of deep-sea anemones is very sparse with only eight records for depths greater than $200 \mathrm{~m}$ off the coast of Brazil: six hormathiids (Actinauge longicornis (Verrill, 1882), Phelliactis capricornis Riemann-Zürneck, 1973, and P. pelophila Riemann-Zürneck, 1973, Monactis vestita (Gravier, 1918), $P$. robusta Carlgren, 1928, and Paraphelliactis labiata Melo et al., 2020) (Riemann-Zürneck, 1986; Melo et al., 2020) and two small burrowing edwardsiids (i.e., Isoscolanthus iemanjae Brandão et al., 2019, and I. janainae Brandão et al., 2019). In addition, no precise information exists for the two individuals of Phelliactis lophohelia Riemann-Zürneck, 1973, collected between $22^{\circ} \mathrm{S}$ and $38^{\circ} \mathrm{S}$ that may represent a ninth deep-sea anemone species from Brazil.

The rate of species discovery since the mid1700 s for cnidarians in South America has plateaued despite showing high levels of endemism in the Brazilian coast (71.6\%: Miloslavich et al., 2011). Among sea anemones, the slow rate of species discovery is likely the result of logistical difficulties in accessing parts of the highly diversified coastline of the country as well as the historically low number of sea anemone taxonomists available to identify this taxon. To improve our understanding of the sea anemone deep-sea diversity in Brazil and across the South Atlantic, we provide complete descriptions, images of external and internal anatomy, microanatomy, cnidae, and geographic distribution for six species collected off the coast of Brazil and four species from the periphery of the south Mid-Atlantic Ridge (SMAR). Four of the species described here represent new records for Brazil and two species have their geographic and bathymetric ranges extended, raising the number of sea anemones recorded in Brazil from 54 to 63 . The four species recorded off the SMAR include a new species, Actinernus mercedae, sp. nov., and three typical deep-sea species found elsewhere in the Atlantic and Southern Ocean. Our study represents an effort toward understanding the diversity and biogeographic patterns of deep-sea anemones in the South Atlantic, a region open to the influence of the Southern Ocean and other oceans and possibly a major corridor to the deep Atlantic oceanic circulation (Milolasvich et al., 2011).

\section{MATERIAL AND METHODS}

This study is based on examination of 24 lots of preserved specimens deposited in the sea anemone collection of the Museu Nacional do Rio de Janeiro (MNRJ) and three additional lots deposited at the American Museum of Natural History (AMNH). Specimens examined were collected in bathyal depths between 394-1694 $\mathrm{m}$ off the coast of Brazil sponsored under various projects (e.g., REVIZEE, OceanProf, Ecoprof PIR 2), and between 1401-4740 m around the southwest of the SMAR (e.g., MARECO) (see fig. 1 for distribution). Type and additional material examined for comparison (see details in descriptions) was from collections from several other institutions: Natural History Museum in London (NMH), National Museum of Natural History in Washington, DC (USNM), Universität Humboldt Museum fur Naturkunde in Berlin (ZMBN), Museum of Zoology of the University of Bergen in Norway (MZB), Uppsala University Zoological Museum in Uppsala (UUZM), Zoological Museum at University of Copenhagen (ZMUC), and Zoo- 


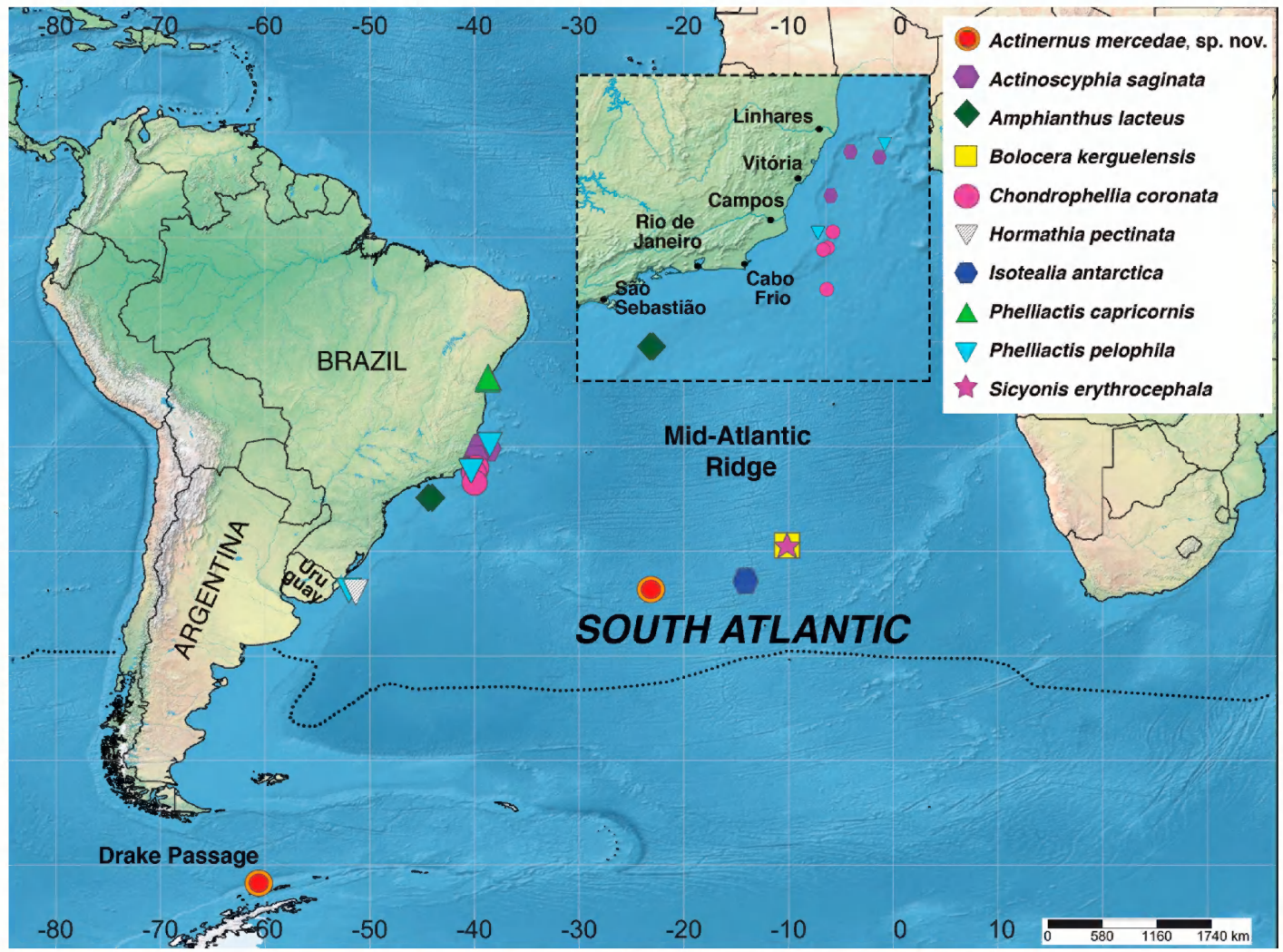

FIG. 1. Localities for each species examined. Dotted line represents the subtropical front and the northern limit of the Southern Ocean.

logical Museum of Hamburg (ZMH). Type material of the new species described here was deposited at the AMNH.

Formalin-fixed specimens were examined whole, dissected, and as serial sections. For microanatomical examination, fragments of one or more individuals, depending on the availability of material, were dehydrated and embedded in paraplast. We made $10 \mu \mathrm{m}$ thick longitudinal and cross-sectional histological sections using standard paraffin techniques and stained them with Heidenhain Azan Stain (Presnell and Schreibman, 1997) and Ramón y Cajal's Triple Stain (Gabe, 1968). We macerated small pieces of tentacles, column, actinopharynx, filaments, and acontia (when present) on slides and fixed them with lactophenol and resin for permanent storage. We identified and measured undischarged cnidae capsules using differentialinterference microscopy (DIC) at $\times 1000$ magnifica- tion; the presence of each type of cnidae in each tissue was also confirmed in histological slides. We measured at least 20 undischarged capsules, except for the rarer types. Range, mean, and standard deviation was calculated for each type of cnida; these are not statistically significant but were provided to give an idea of size distribution of capsules. We followed the nematocyst terminology described by Gusmão et al. (2018), which is an adaptation from the terminology provided by Sanamyan et al. (2012) and provides enough resolution to differentiate and classify capsules of mastigophores. We also included photographs of each type of nematocyst for reliable comparison across terminologies and taxa (see Fautin, 1988). Higher-level classification for Actiniaria follows Rodríguez et al. (2014). All generic diagnoses have been modified to incorporate the nematocyst terminology and higherlevel classification used in the study. 


\section{RESULTS}

\section{TAXONOMIC DESCRIPTIONS}

Order Actiniaria Hertwig, 1882

Suborder Anenthemonae Rodríguez and Daly, 2014, in Rodríguez et al., 2014

Superfamily Actinernoidea Stephenson, 1922

Family Actinernidae Stephenson, 1922

Genus Actinernus Verrill, 1879

Diagnosis (modified from Carlgren, 1949; Uchida, 2007; modifications in bold): Actinernidae with thick column distally expanded, usually forming eight lobes. No marginal sphincter musculature. Tentacles, except youngest and rarely inner ones, with aboral thickenings of varying development that may run up the tentacles almost to their tips. Arrangement of tentacles usually in two cycles, largest tentacles at apices of lobes. Longitudinal muscles of tentacles ectodermal, weak, radial muscles of oral disc ectodermal. Two well-developed siphonoglyphs. Numerous perfect mesenteries; after the first $\mathbf{1 0}$ pairs (first and second cycles), mesenteries appear bilaterally in the middle point of each of the eight lateral endoceles, and are unequally developed. Retractors and parietobasilar musculatures weak. Cnidom: Spirocysts, basitrichs, $\boldsymbol{b}$-mastigophores, $\boldsymbol{p}$-mastigophores $\mathbf{A}$.

Type SPECIEs: Actinernus nobilis Verrill, 1879, by original designation.

VALID SPECIES: Actinernus. antarcticus (Carlgren, 1918); A. elongatus (Hertwig, 1882); A. michaelsarsi Carlgren, 1918; A. nobilis; A. robustus (Hertwig, 1882) (Rodríguez and LópezGonzález, 2013).

Actinernus mercedae, sp. nov., Gusmão, López-González, Rodríguez

Figures $2-3$, table 1

Material: Holotype AMNH 4028 (1 specimen); locality: ANT XIX/3, ANDEEP I Program, RV Polarstern, Sta. PS61/114-10, Southern Ocean, Drake Passage, Antarctica, $61^{\circ} 43.70^{\prime} \mathrm{S}$ $60^{\circ} 42^{\prime} \mathrm{W}$, collected on 19 February 2002 (2853$2856 \mathrm{~m}$ ). Paratypes AMNH 4078 (3 specimens, same collection data as holotype). Paratype AMNH 4035 (1 specimen, same collection data as holotype). MNRJ 8183 (3 specimens); locality: Ak. Ioffe Cruise 29, Superestação 10, Sta. 202, series \#1044, South Mid-Atlantic Ridge, $33^{\circ} 40.07^{\prime} \mathrm{S} 23^{\circ} 05.57^{\prime} \mathrm{W}$, collected on 23 November 2009 by MAR-ECO \#38216 (4740 m).

Material examined: Actinernus michaelsarsi: USNM 88367/386969 (1 specimen; holotype); locality: United States, North Atlantic Ocean, Blake Plateau, 350 mile ESE of Charleston, South Carolina at the Wreck Site of S.S. Central America, $31^{\circ} 30^{\prime} \mathrm{N} 77^{\circ} 00^{\prime} \mathrm{W}$, collected Sept 1989 by Columbus America Discovery Group; Herdendorf, C. E.; Evans, R.; by Arctic Discoverer R/V and Nemo DSR/V (2200 m). Porponia antarctica Carlgren, 1914: NMSZ 1921.143.1756 (2 specimens; syntypes); locality: Scotia Collection, off Coats Land, $71^{\circ} 22^{\prime} \mathrm{S}$ $16^{\circ} 34^{\prime} \mathrm{W}$, collected on 16 March 1904 (2578 m). NMSZ 1921.143.1756 (1 specimen; syntype, same collection data as other syntypes). Porponia elongata Hertwig, 1882: NHM 1889.11.25.29 (2 specimens; syntypes); locality: Challenger Collection, Sta. 160, collected on 13 March 1874 (4755 m). Porponia robusta Hertwig, 1882: NHM 1889.11.25.30 (1 specimen; holotype); locality: Challenger Collection, Sta. $237,34^{\circ} 37^{\prime} \mathrm{N} 140^{\circ} 32^{\prime} \mathrm{E}$ (3429 m). Isactinernus quadrilobatus Carlgren, 1918: UUZM [Typsamlingen nr 102 a (Anthozoa)]. Syntype. "Dr Sixten Bocks Japan Exp. 1914, KIUSCHIU, Goto Islands, Osesaki, 23 miles NV t.V 1/2V-122 ${ }^{\circ} 10^{\prime}$ Ost, 165 m, datum: 14/5, formol, Type" (1 specimen). UUZM [Typsamlingen nr 102 b (Anthozoa)]. Syntype "Dr Sixten Bocks Japan exp. 1914, KIUSCHIU, Goto Islands, Osesaki, c.a $170 \mathrm{~m}$, datum: 14/5, formol, Isactinernus 4-lobatus orig: determ. Carlgren" (1 specimen). Synactinernus flavus Carlgren, 1918: UUZM. [Typsamlingen nr 232 (Anthozoa)]. Holotype. "Dr Sixten Bocks Japan Exp. 1914, KIUSCHIU, Goto Islands, 28 miles N, 1/2 Ost frain Shirase fyr, $128^{\circ} 50^{\prime}$ O.L. $33^{\circ} 41^{\prime} \mathrm{N} \mathrm{Br}, 110 \mathrm{~m}$, datum: 
17/5; botten: sand, formol. Synactinernus flavus orig: determ. Carlgren."

EXTERNAl ANATOMY (fig. 2): Body short and broad in preserved specimens, with an inverted triangle shape (fig. 2A, B). Pedal disc well developed, small, flat or slightly curved, rectangular; up to $8 \mathrm{~mm}$ in diameter in preserved specimens (fig. 2B). Column smooth, not divisible into regions, widened distally, rectangular (flattened in one axis) (fig. 2A, B); with cartilaginous texture (fig. 2B). Column up to $31 \mathrm{~mm}$ in diameter and $39 \mathrm{~mm}$ in length in preserved specimens. Oral disc wider than column in preserved specimens (fig. 2B), forming at least four lobes (fig. 2C) in preserved specimens and eight in live ones (fig. 2A). Oral disc up to $44 \mathrm{~mm}$ in diameter in preserved specimens; apparently nonretractable. Margin of column tentaculate (fig. 2A, $\mathrm{B}, \mathrm{D})$. Tentacles 59-62, long, very slender, pointed, of "filamentous" aspect (fig. 2A-C), with prominent mesogleal basal aboral thickenings of triangular shape in preserved specimens (fig. 2D, E); longest tentacle up to $15 \mathrm{~mm}$.

INTERNAL ANATOMY AND HISTOLOGY (fig 2): Marginal sphincter musculature absent (fig. 2F). Base of tentacles with mesogleal aboral thickening (fig. 2F, G); longitudinal tentacle musculature ectodermal (fig. 2H). Actinopharynx short, approximately one third of column's length, longitudinally sulcated throughout. Two sectioned specimens with up to 46 mesenteries in four cycles distally $(6+4+8+5$ pairs) (fig. $2 \mathrm{~J})$; mesenteries after first 6 pairs on lateral endoceles of first cycle with retractor muscles as in directives; after second cycle $(6+4=10$ pairs $)$, mesentery formation bilateral in middle zone of lateral endoceles. All mesenteries perfect, including two pairs of directives, each associated with one siphonoglyph (fig. 2I-J), except 4-8 imperfect mesenteries (depending on specimen) of third and fourth cycles. In third and fourth cycle, mesenteries within same pair unequally developed (fig. $2 \mathrm{~K}$ ). More mesenteries distally than proximally. Thirty-five mesenteries proximally in three cycles; all mesenteries with filaments and gametogenic tissue. All specimens collected in
November sterile; those collected in February with weakly developed spermatic cysts in all mesenteries. Retractors of all mesenteries weak, short, diffuse (fig. 2L), difficult to discern; parietobasilar musculature very weak in all mesenteries (fig. 2M). Basilar musculature of mesenteries absent (fig. $2 \mathrm{~N}$ ).

Cnidom (fig. 3): Spirocysts, basitrichs, $b$-mastigophores, $p$-mastigophores $\mathrm{A}$, and holotrichs. See figure 3 and table 1 for size and distribution.

Distribution AND NATURAL HISTORY: Specimens of Actinernus mercedae, sp. nov., were collected in the Southern Ocean in the Drake Passage $\left(61^{\circ} 43.70^{\prime} \mathrm{S}, 60^{\circ} 42.62^{\prime} \mathrm{W}\right)$ between 2852-2856 m, and in the South Atlantic, east of the Mid-Atlantic Ridge at $4740 \mathrm{~m}$ depth.

Eтymology: This species is named after Mercedes Conradi (Universidad de Sevilla, Spain), who kindly collected, photographed, and preserved specimens of the new species for the first time.

REMARKs: After the revision of the type material and newly collected material, Rodríguez and López-González (2013) considered five valid species for Actinernus: A. antarcticus, A. elongatus, A. michaelsarsi, A. nobilis, A. robustus, and two new undescribed species from Antarctica (E.R., personal obs.). Uchida (2007) considered the same five valid species of Actinernus. Contra Fautin (2016), Rodríguez and López-González (2013) formalized this point of view on the membership of Actinernus, rejecting the synonymy of $A$. antarcticus and $A$. elongatus by Dunn (1983) and considered $A$. antarcticus valid. Here we describe Actinernus mercedae, which is placed within the genus due to its lobed column that is more developed distally, absence of marginal sphincter musculature, distinct mesogleal thickenings on aboral side of tentacles, mesenterial arrangement following the Endocoelantheae plan (see Carlgren, 1949), two siphonoglyphs and weak retractor and parietobasilar musculatures. Actinernus mercedae resembles other two genera within the family (Isactinernus Carlgren, 1918, and Synactinernus Carlgren, 1918) because it has a lobed distal column (Carlgren, 1949; Uchida, 2007). 


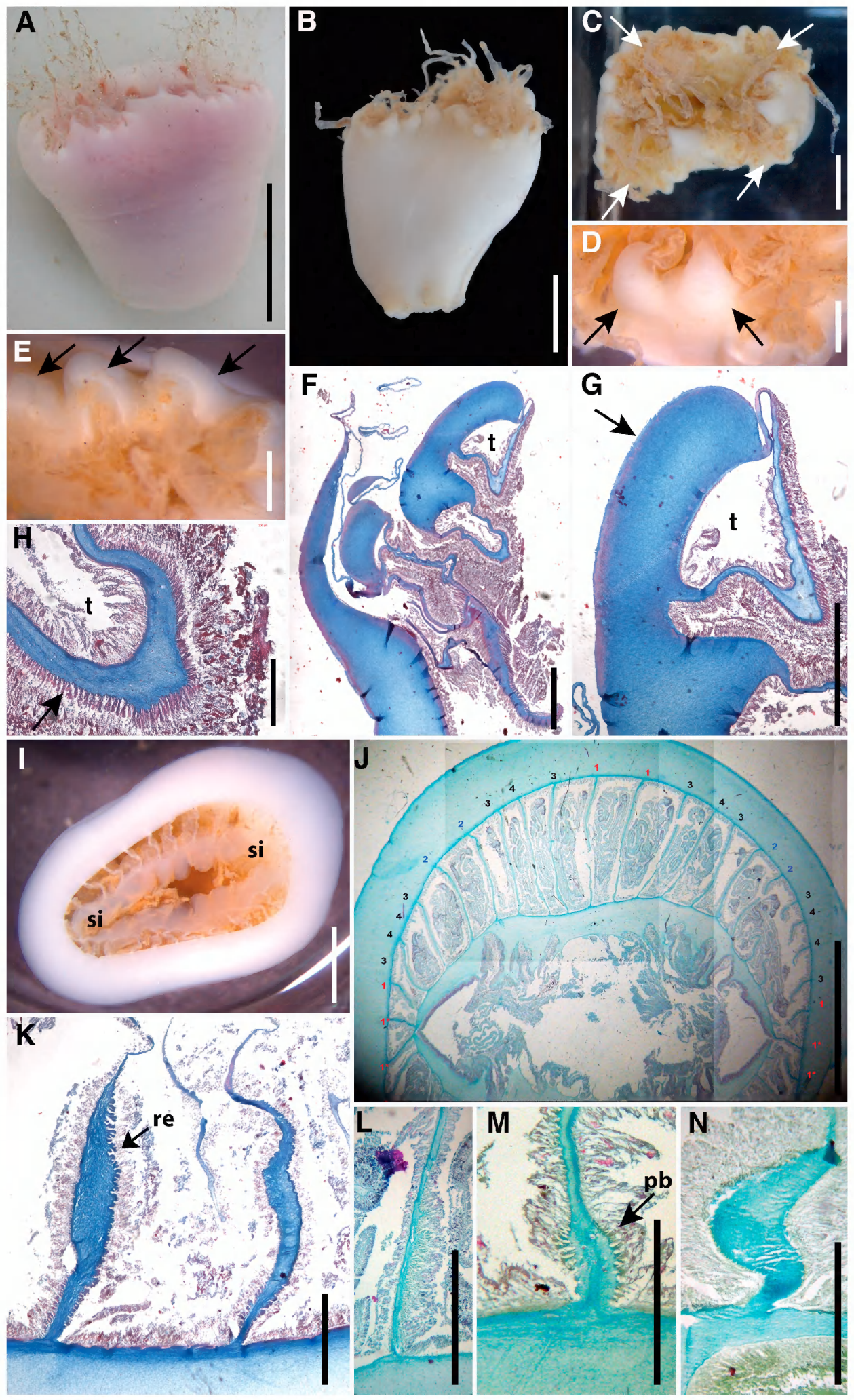


However, it can be easily distinguished from those genera because of the bilateral arrangement of the younger mesenteries in Actinernus (cyclic in the other two genera, Carlgren, 1918; Uchida, 2007; Izumi et al., 2019) and the distinct mesogleal aboral thickenings in the base of the tentacles in Actinernus (not distinct in the other two genera) (Izumi et al., 2019); furthermore, the lobes in species of Actinernus are not as marked as those in the other two genera (see Izumi et al., 2019). Actinernus mercedae is the third species of the genus described for the Southern Ocean: Actinernus antarcticus and A. mercedae are present in the Atlantic portion of Antarctica whereas A. elongatus is known from the sub-Antarctic Indian Ocean. Because the internal anatomy of members of Actinernus is often hard to observe due to preservation issues, the only characters to show consistent anatomical differences between the valid species of Actinernus in the Southern Ocean are the development and shape of the basal aboral thickenings of the tentacles (Rodríguez and López-González, 2013). However, the number of mesenteries and their arrangement and their perfect or imperfect nature also seem to differ among the species. Actinernus mercedae is easily differentiated from all other species of the genus in the Southern Ocean by the more or less defined oral disc lobes with very conspicuous triangular mesogleal aboral thickenings in tentacles (fig. 2A). Though Dunn (1983) hypothesized that the lobes in the oral disc of Actinernus spp. are artefacts of the contraction of tentacles (Fautin and den Hartog, 2003), specimens of A. mercedae display lobes in the oral disc even in extended state (fig. 2A). Actinernus mercedae can be differentiated from $A$. elongatus by the rounded mesogleal aboral thickenings in tentacles of this species, and by the gradual decrease in diameter between the basal aboral thickenings and the tentacles as well as for the morphology of the tentacles themselves in A. antarcticus (i.e., filiform tentacles in A. antarcticus vs. filamentous tentacles in $A$. mercedae) (see fig. 4). In addition, the number of mesenteries differs between A. antarcticus and A. mercedae (i.e., up to 68 mesenteries in A. antarcticus vs. 46 in A. mercedae; see Carlgren, 1914, 1918, for $A$. antarcticus). Given our current lack of understanding about the distribution of cnidae in species of Actinernus, we should not use this character for specific identification (Rodríguez and LópezGonzález, 2013). However, we acknowledge that the cnidae of our specimens differ from that of $A$. antarcticus in the presence of spirocysts and two categories of $p$-mastigophores $\mathrm{A}$ in the column; presence of $p$-mastigophores A and lack of $b$-mastigophores and small basitrichs in tentacles; lack of spirocysts and smaller basitrichs and presence of two kinds of $p$-mastigophores in the filament. Geographic distribution also varies among valid species of Actinernus in the Southern Ocean: A. antarcticus is known from

FIG. 2. External and internal anatomy and histology of Actinernus mercedae, sp. nov. A, Lateral view of live specimen; B, lateral view of preserved specimen; $\mathbf{C}$, oral view of preserved specimen showing oral disc divided in four lobes (indicated by arrows); note filamentous aspect of tentacles; D, detail of tentaculate margin; note tentacles with mesogleal basal aboral thickening (arrows); E, oral view of tentacles and mesogleal basal aboral thickening (arrow); F, longitudinal section through distal column; note absence of marginal sphincter musculature; G, longitudinal section through an outer tentacles and mesogleal basal aboral thickening (arrow); $\mathbf{H}$, longitudinal section through a tentacle and ectodermal musculature (arrow); I, cross section through distal column showing arrangement of mesenteries at actinopharynx level; J, histological cross section at actinopharynx level showing arrangement of mesenteries; K, detail of a pair of mesenteries with diffuse retractor musculature (arrow); L, detail of diffuse retractor musculature; $\mathbf{M}$, cross section through a mesentery with weak parietobasilar musculature; $\mathbf{N}$, histological longitudinal section through pedal disc and absence of basilar musculature. Abbreviations: di, directive mesenteries; re, retractor musculature; pb, parietobasilar musculature; si, siphonoglyph; b tentacle. Scale bars: A, $30 \mathrm{~mm}$;, $10 \mathrm{~mm}$; C, J, $5 \mathrm{~mm}$; D-G, $2 \mathrm{~mm}$; $0.2 \mathrm{~mm}$;, 4 $\mathrm{mm} ; \mathbf{K}-\mathbf{L}, \mathbf{N}, 0.5 \mathrm{~mm} ; \mathbf{M}, 0.3 \mathrm{~mm}$. 


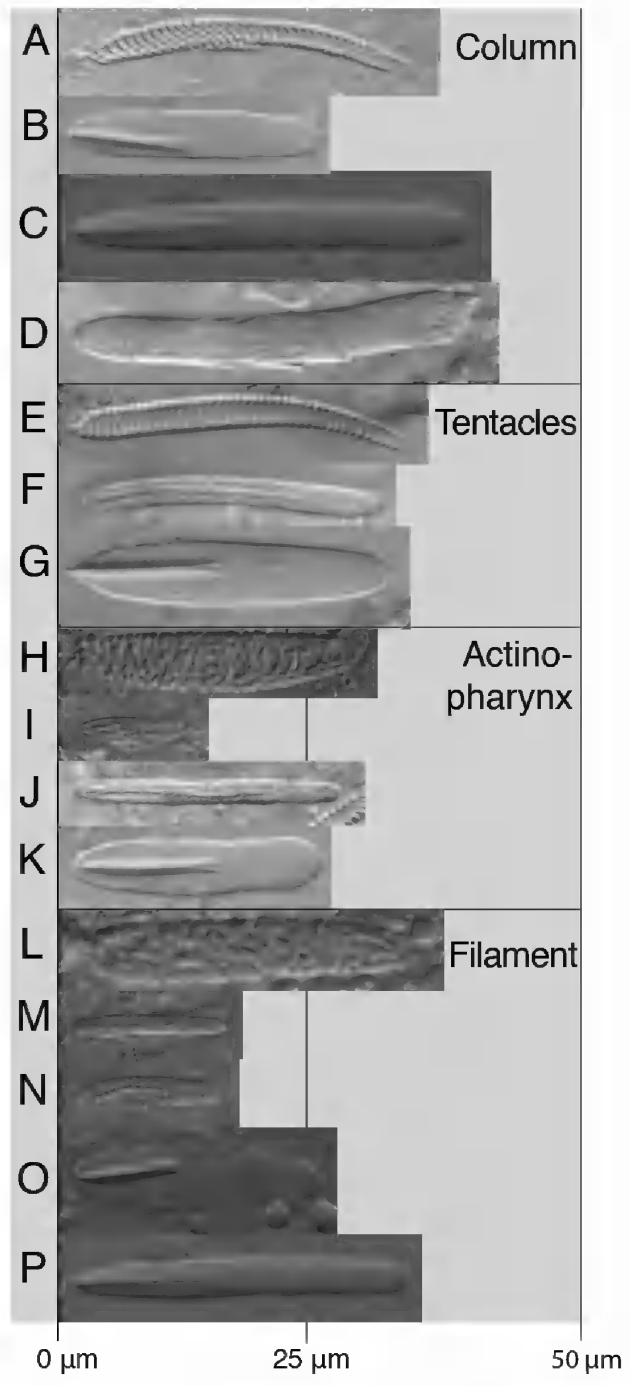

FIG. 3. Cnidom of Actinernus mercedae: A, E, H, L, spirocyst; $\mathbf{B}, \mathbf{C}, \mathbf{G}, \mathbf{K}, \mathbf{O}, \mathbf{P}, p$-mastigophore A; D, holotrich; F, J, M, basitrich; I, N, b-mastigophore.

Antarctic waters (Kapp Norvegia and Antarctic Peninsula) whereas A. elongatus is known from sub-Antarctic waters of the Indian Ocean. Actinernus mercedae is known from its type locality in the Drake Passage and in the South Atlantic outside the sub-Antarctic region $\left(\sim 33^{\circ}\right.$ $S)$ at depths similar to records of $A$. elongatus (i.e., $4750 \mathrm{~m}$ ) (Rodríguez and López-González, 2013). Of the three species of Actinernus distributed in the northern hemisphere, Actinernus mercedae resembles A. robustus from Japan in the shape of the tentacular mesogleal aboral thickenings and lobed column (see Hertwig, 1882; Carlgren, 1918; Uchida, 2007). The circumscription of characters in A. robustus is not very clear since the single specimen examined and described by Carlgren (1918) besides the holotype (that of Hertwig, 1882) differs relative to the holotype (i.e., large specimen: up to 75 $\mathrm{mm}$ in column height and up to 190 tentacles, eight lobes of similar size, companions in younger developing pairs of mesenteries of similar size, depth 150-600 m) to the holotype and the additional material examined by Uchida (2007), i.e., up to $40 \mathrm{~mm}$ height and up to 90 tentacles, eight lobes divided in four bigger and four smaller ones, companions in newly developed pairs of unequal size, depth 1115-3429 $\mathrm{m}$.These differences led Uchida (2007) to hypothesize that there are probably two species in Japan. In addition, Uchida's interpretation of the formation of the mesenteries in Actinernus differs slightly from that of Carlgren (1918, 1949). Although both authors agree in that after the second cycle mesenteries appear bilaterally in each of the lateral endoceles, for Uchida (2007) new pairs of mesenteries appear in the middle zone of each of the eight lateral endoceles and are of unequal size, whereas for Carlgren new mesenteries in a pair usually grow from the outer side of the octant inward and are of similar size (Carlgren, 1918, fig. 13). Corroborating the formation and arrangement of the younger pairs of mesenteries is hard in these species because of the weak and diffuse nature of the retractors and its preservation in the rather few specimens available. In the examined specimens of $A$. mercedae (AMNH 4078, MNRJ 8183) unequally developed companions corresponding to the third and fourth cycle of mesenteries are present in the same octant at the actinopharynx level, whereas in A. robustus mesenteries companions of a pair are of unequal size from the fourth cycle on in the same octant at a similar level (Uchida, 2007). There are also differences in the cnidae of both species (see 


\section{TABLE 1}

Size ranges of the cnidae of Actinernus mercedae sp. nov.

Abbreviations and symbols: SD, standard deviation; $N$, Total number of capsules measured; $\mathrm{S}$, proportion of specimens in which each cnidae was found; $\mathrm{F}$, frequency; +++, very common; ++ , common; +, rather common; -, rare.

\begin{tabular}{|c|c|c|c|c|c|}
\hline Categories & $\begin{array}{l}\text { Range of length and width of } \\
\text { capsules }(\mu \mathrm{m})\end{array}$ & Mean \pm SD & $N$ & S & $\mathbf{F}$ \\
\hline \multicolumn{6}{|l|}{ Column } \\
\hline Spirocysts (A) & $22.5-67.0 \times 2.4-6.8$ & $49.0 \pm 10.2 \times 4.8 \pm 1.0$ & 47 & $2 / 2$ & + \\
\hline$P$-mastigophores A I (B) & $24.0-32.6 \times 4.2-6.7$ & $27.9 \pm 2.0 \times 5.5 \pm 0.8$ & 39 & $2 / 2$ & ++ \\
\hline$P$-mastigophores A II (C) & $32.2-54.8 \times 3.1-4.8$ & $37.6 \pm 3.4 \times 3.8 \pm 0.3$ & 63 & $2 / 2$ & +++ \\
\hline Holotrich pieces (D) & $42.5 \times 4.1$ & - & 1 & $1 / 2$ & - \\
\hline \multicolumn{6}{|l|}{ Tentacles } \\
\hline Spirocysts (E) & $18.5-75.0 \times 1.8-20.0$ & $31.0 \pm 9.7 \times 4.8 \pm 2.5$ & 180 & $4 / 4$ & +++ \\
\hline Basitrichs (F) & $23.6-54.0 \times 1.8-5.0$ & $29.9 \pm 5.3 \times 2.8 \pm 0.7$ & 222 & $4 / 4$ & +++ \\
\hline$P$-mastigophores A (G) & $24.6-34.3 \times 5.5-6.7$ & $28.7 \pm 2.7 \times 6.1 \pm 0.4$ & 17 & $2 / 4$ & + \\
\hline \multicolumn{6}{|l|}{ ACTINOPHARYNX } \\
\hline Spirocysts $(\mathrm{H})$ & $29.0-69.0 \times 3.1-13.0$ & $49.6 \pm 11.0 \times 9.3 \pm 2.4$ & 26 & $3 / 4$ & + \\
\hline$B$-mastigophores (I) & $12.7-27.7 \times 2.1-5.2$ & $21.7 \pm 3.7 \times 3.5 \pm 0.9$ & 46 & $4 / 4$ & + \\
\hline Basitrichs II (J) & $33.4-51.0 \times 2.4-6.0$ & $41.1 \pm 4.7 \times 3.8 \pm 0.7$ & 115 & $4 / 4$ & +++ \\
\hline$P$-mastigophores A (K) & $20.9-53.0 \times 3.2-10.0$ & $42.9 \pm 6.7 \times 7.5 \pm 1.3$ & 53 & $3 / 4$ & + \\
\hline \multicolumn{6}{|l|}{ Filament } \\
\hline Spirocysts (L) & $41.0-48.0 \times 7.0-10.0$ & $44.1 \pm 2.3 \times 8.6 \pm 1.0$ & 6 & $1 / 4$ & - \\
\hline Basitrichs I (M) & $14.6-25.4 \times 2.4-3.7$ & $19.0 \pm 3.5 \times 2.9 \pm 0.4$ & 12 & $2 / 2$ & ++ \\
\hline B-mastigophores I (N) & $14.6-46.0 \times 2.4-5.0$ & $27.9 \pm 10.8 \times 4.0 \pm 0.6$ & 128 & $4 / 4$ & +++ \\
\hline$P$-mastigophores A I $(\mathrm{O})$ & $21.5-30.0 \times 3.7-6.3$ & $25.9 \pm 1.9 \times 5.5 \pm 1.2$ & 82 & $4 / 4$ & +++ \\
\hline$P$-mastigophores A II (P) & $21.5-42.0 \times 2.6-10.0$ & $33.4 \pm 3.8 \times 5.2 \pm 2.1$ & 125 & $4 / 4$ & +++ \\
\hline
\end{tabular}

table 1 and Uchida, 2007): p-mastigophores $\mathrm{A}$ in the tentacles of $A$. mercedae are absent in $A$. robustus and basitrichs in the tentacles $A$. mercedae are longer than in $A$. robustus; two categories of $p$-mastigophores in the column of $A$. mercedae are absent in $A$. robustus and basitrichs present in the column of $A$. robustus are absent in A. mercedae; a category of short basitrichs in the actinopharynx $A$. mercedae is absent in $A$. robustus; one category of $p$-mastigophores $\mathrm{A}$ and $b$-mastigophores in the filaments of $A$. mercedae are absent in $A$. robustus which also has holotrichs in the filaments that are absent in $A$. mercedae. The two species from the North Atlantic (A. michaelsarsi and A. nobi- lis) can be differentiated from A. mercedae by the weak mesogleal aboral thickenings of their tentacles (prominent in $A$. mercedae) and by the number of tentacles (59-62 tentacles in A. mercedae vs. approximately 120 tentacles in $A$. nobilis and 70 in A. michaelsarsi) (Uchida, 2007). We also find some variability within specimens of A. mercedae from the Southern Ocean and the SMAR (e.g., cnidae); however, we attribute these slight differences to interpopulation variability. Actinernus mercedae is the sixth species of the genus worldwide. Authorship of this species recognizes P. López-González's contribution to earlier work that is included in this larger manuscript. 

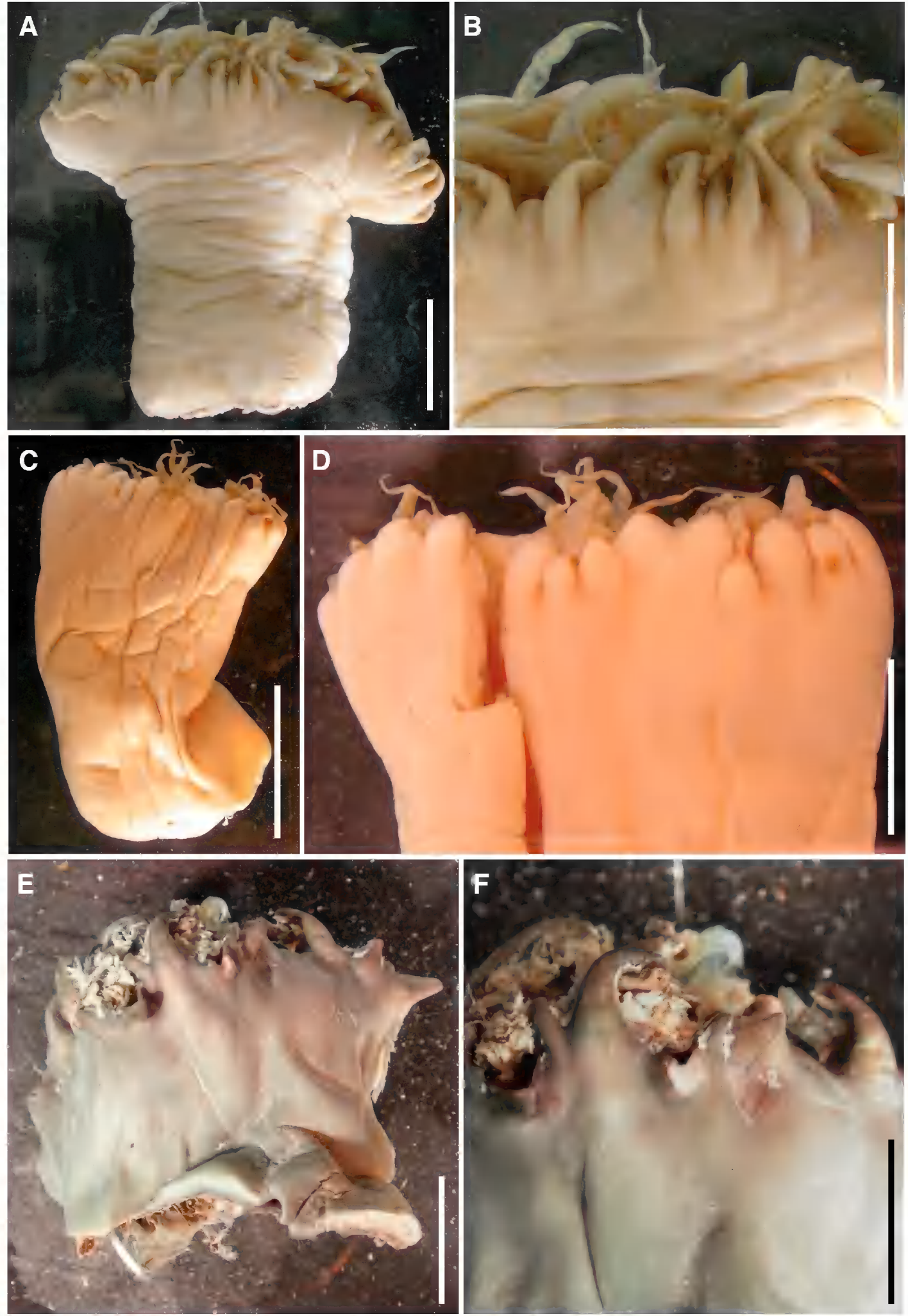
Suborder Enthemonae Rodríguez and Daly in Rodríguez et al., 2014

Superfamily Actinostoloidea Carlgren, 1932

Family Actinostolidae Carlgren, 1932

Genus Sicyonis Hertwig, 1882

Diagnosis (modified from Carlgren, 1949; modifications in bold): Actinostolidae with welldeveloped pedal disc and rather thick column; tentacles covered by distal column. Mesogleal marginal sphincter musculature weak or fairly well developed. Tentacles short, inner ones considerably stronger than outer ones and about half as numerous as mesenteries; aboral base of tentacles often thickened. Longitudinal muscles of tentacles and radial muscles of oral disc mesogleal. Two broad siphonoglyphs. Often 16 pairs of perfect mesenteries with a variable number of pairs with one perfect and one imperfect mesentery. Arrangement of mesenteries not as regular as in Actinostola, but with strong tendency to unequal development of mesenteries in a pair. Retractors weak, diffuse, and parietobasilar and basilar musculatures well developed. Mesenteries differentiated into stronger, fertile mesenteries with well-developed filaments and into weaker fertile mesenteries without filaments proximally $h$ do not reach the distalmost part column. Cnidom: spirocysts, basitrichs, $\boldsymbol{p}$-mastigophores $\mathbf{A}$.

Type species: Sicyonis crassa Hertwig, 1882, by original designation.

VAlid SPECIES: Sicyonis careyi Eash-Loucks and Fautin, 2012; S. crassa; S. erythrocephala (Pax, 1922); S. gossei (Stephenson, 1918b); S. haemisphaerica Carlgren, 1934; S. heliodiscus Sanamyan et al., 2015; S. ingolfi Carlgren, 1921; S. obesa (Carlgren, 1934); S. sumatriensis Carl- gren, 1928a; S. tuberculata Carlgren, 1921; S. tubulifera (Hertwig, 1882); S. variabilis Carlgren, 1921 (Fautin, 2016).

\section{Sicyonis erythrocephala (Pax, 1922)}

Figures 5-6, table 2

MATERIAL: MNRJ 8167 (4 specimens); locality: Mid-Atlantic Ridge, Ak. Ioffe Cruise 29, Superestação 7, Sta. 201, series \#1030, $29^{\circ} 27.12^{\prime}$ S $10^{\circ} 08.72^{\prime}$ W, collected on 20 November 2009 by MAR-ECO \#38295, Shirshov St. 2184-5 (4120 m).

Material exAmined: Stomphia selaginella (Stephenson, 1918a): AMNH 4326 (20 specimens); locality: ANT XV/3 Cruise, EASIZ II Program, RV Polarstern, Sta. PS48/220, Southern Ocean, Antarctica, Weddell Sea, Austassen, $70^{\circ} 50.40^{\prime} \mathrm{S} 10^{\circ} 35.40^{\prime} \mathrm{W}$, collected on 19 February 1998 by P. López-González ( $236 \mathrm{~m})$. Actinos tola crassicornis (Hertwig, 1882): AMNH 4698 (3 specimens); locality: ANT XIX/5 Cruise, LAMPOS Program, RV Polastern, Sta. 61/153, Burd-

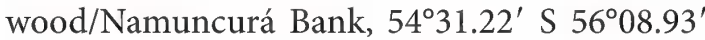
W, collected on 6 April 2002 by E. Rodríguez (277 m). Actinostola georgiana Carlgren, 1927: AMNH 4803 (1 specimen); locality: ANT XXI/2 Cruise, BENDEX Program, RV Polarstern, Sta. PS65/019-1, Southern Ocean, Bouvet Island,

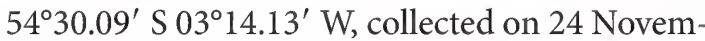
ber 2003 by E. Rodríguez $(247 \mathrm{~m})$.

External anatomy (fig. 5): Pedal disc small, circular, flat, $25-40 \mathrm{~mm}$ in diameter in preserved specimens (fig. 5A). Column firm, cylindrical, tall, smooth, not divisible into regions (fig. 5A); margin tentaculate (fig. 5B). Column white/light beige (fig. $5 \mathrm{~A}$ ); $35-50 \mathrm{~mm}$ in diameter and $10-49$ $\mathrm{mm}$ in length in preserved specimens. Oral disc circular, as wide or slightly wider than column,

FIG. 4. External anatomy of type specimens of Actinernus (Hertwig, 1882) showing basal aboral thickening and tentacle morphology. A, Lateral view of A. antarcticus (Carlgren, 1914) (NMSZ 1921.143.1756, syntype); B, detail of distal margin of column and basal aboral thickening of tentacles (NMSZ 1921.143.1756, syntype); C, lateral view of A. elongatus (Hertwig, 1882) (NHM 1889.11.25.29, syntype); D, detail of distal margin of column and basal aboral thickening of tentacles of of A. elongatus (Hertwig, 1882) (NHM 1889.11.25.29, syntype); E, lateral view of $A$. robustus (Hertwig, 1882) (NHM 1889.11.25.30, holotype); F, detail of margin of column and basal aboral thickening of tentacles of A. robustus (NHM 1889.11.25.30, holotype). Scale bars: A, C, $25 \mathrm{~mm}$; B, $20 \mathrm{~mm}$; D-F, $10 \mathrm{~mm}$. 

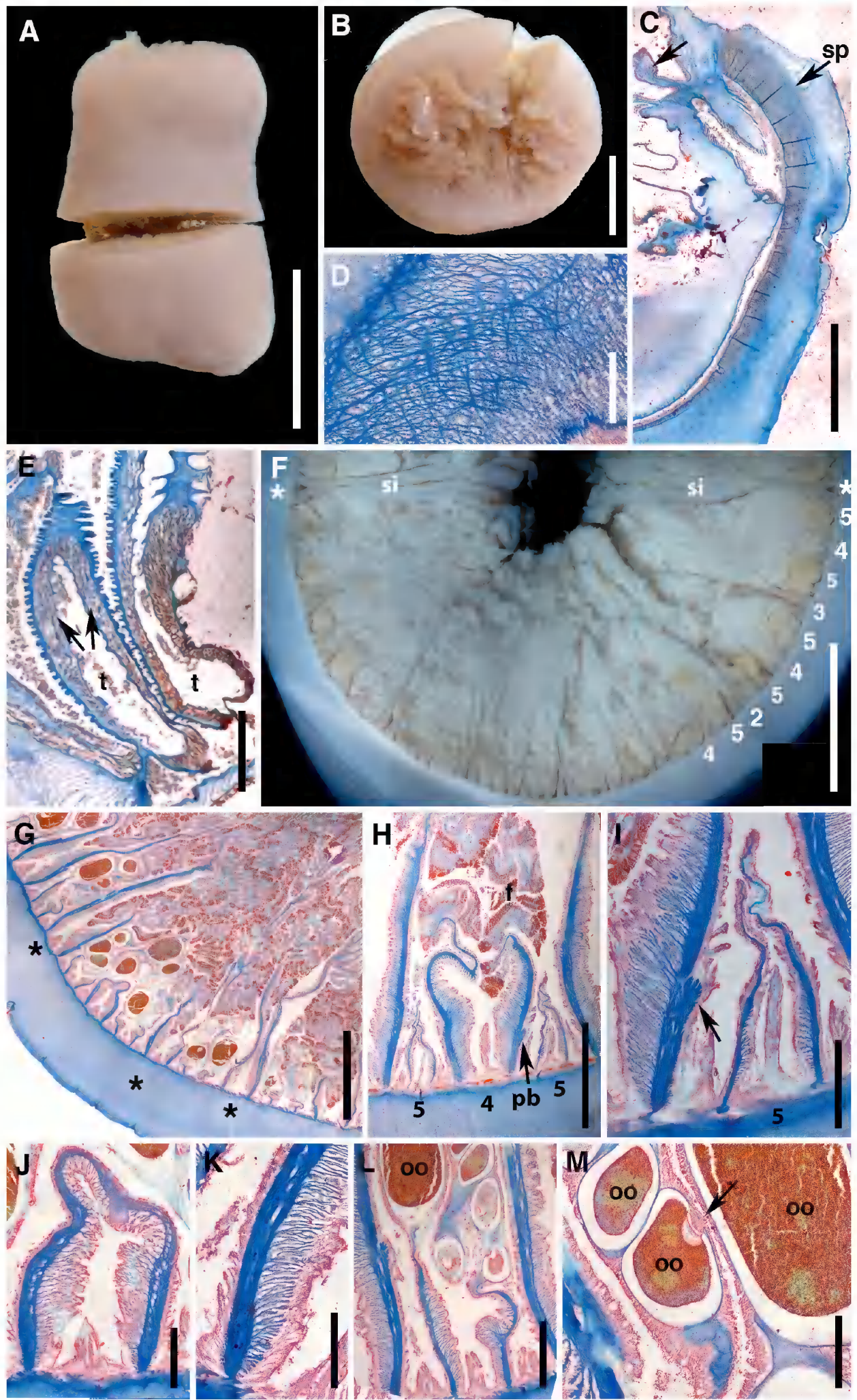
with central mouth, same color as column (fig. $5 \mathrm{~B})$; $30-48 \mathrm{~mm}$ in diameter in preserved specimens. Tentacles approximately 132, smooth, short, pointed, with no markings, in $2-3$ cycles on outer half of oral disc (fig. 5B); all tentacles translucent beige in preserved specimens (fig. $5 B)$. Inner tentacles slightly longer than outer ones (fig. 5B); longest tentacle up to $18 \mathrm{~mm}$ in preserved specimens.

INTERNAL ANATOMY AND HISTOLOGY (fig. 5): Body-wall thickness uniform throughout column with thin gastrodermis and thick mesoglea (fig. 5C); epidermis of column mostly absent (fig. 5C). Marginal mesogleal sphincter musculature weak, diffuse, with fibers mostly close to gastrodermis and narrow proximally (fig. 5C); muscle fibers with reticular arrangement in mesoglea (fig. 5D). Longitudinal musculature of tentacles mesogleal (fig. 5E).

Mesenteries irregularly arranged in five cycles, 68 pairs at midcolumn; more mesenteries proximally than distally. Approximately 16 mesenteries of first and second cycles, perfect, including two pairs of directives, each associated with one siphonoglyph (fig. 5F); third to fifth cycles imperfect, with filaments (fig. 5F, G). Fifth cycle of mesenteries imperfect, fertile (fig. 5F). Mesenteries in pairs of third to fifth cycle unequally developed (fig. 5G). Anomalous pair of fourth cycle fused (fig. 5J). Oocytes 1-5 per mesentery in various stages of development, including pre- and early vitellogenic oocytes (fig. 5L, M), with trophonema (arrow: fig. 5M). All specimens collected in November female; major axis of oocytes up to $0.9 \mathrm{~mm}$. Species inferred gonochoric. Retractors of all mesenteries weak, diffuse (fig. $5 \mathrm{G}-\mathrm{I}$ ); parietobasilar of larger mesenteries well developed with free mesogleal flap (fig. 5I); rest of mesenteries with weak to indistinct parietobasilar musculature (fig. $5 \mathrm{~K}$ ).

CNidom (fig. 6): Spirocysts, basitrichs, $p$-mastigophores A. See figure 6 and table 2 for size and distribution.

Distribution AND NATURAL HISTORY: Sicyonis erythrocephala was originally recorded from the Bellingshausen Sea in the Antarctic Peninsula (Pax, 1922; Carlgren, 1927). After Fautin (1984) synonymized S. aurora Carlgren and Stephenson, 1929, and S. antarctica Carlgren, 1939, with $S$. erythrocephala, the species is also known from Tasmania (Carlgren and Stephenson, 1929), off Coats Land in the Weddell Sea (Carlgren, 1939) and all around Antarctica up to $42^{\circ} \mathrm{S}$ (Fautin, 1984). Thus, S. erythrocephala is mostly a widespread Antarctic species distributed in three districts of the Southern Ocean (i.e., Atlantic, Pacific, and Indian sensu Rodríguez et al., 2007). Our material significantly extends the geographic range of the species further north to the SMAR $\left(\sim 29^{\circ} \mathrm{S}\right)$ and is the deepest record for the species, extending the bathymetric range of the species from $3879 \mathrm{~m}$ to $4120 \mathrm{~m}$.

FIG. 5. External and internal anatomy and histology of Sicyonis erythrocephala (Pax, 1922). A, Lateral view of dissected preserved specimen; B, oral view of preserved specimen showing tentaculate margin; $\mathbf{C}$, longitudinal section through distal column showing long, narrow marginal mesogleal sphincter musculature; note mesogleal longitudinal musculature of tentacles (arrow) D, detail of alveolar arrangement in mesoglea of sphincter musculature; E, detail of mesogleal longitudinal musculature of tentacles (arrows); F, cross section through midcolumn and cycles of mesenteries and fertility; note two pairs of directive mesenteries (indicated by asterisks) each attached to one siphonoglyph; G, cross section through midcolumn and cycles of mesenteries and unequal mesenteries in a pair (asterisks) and their fertility; $\mathbf{H}$, detail of a pair of mesenteries of fourth cycle and strong, diffuse retractor musculature and parietobasilar muscle with separate flap (arrow); I, detail of pair of mesentery of fifth cycle with short, diffuse retractor musculature; note parietobasilar of first cycle (arrow); J, anomalous mesentery; K, detail of parietobasilar musculature of a mesentery of second cycle; L, detail of a pair of mesenteries of fifth cycle with oocytes in varying degrees of development; $\mathbf{M}$, detail of preand early vitellogenic oocytes; note trophonema (arrow). Abbreviations: oo, oocytes; f, filaments; pb, parietobasilar musculature; si, siphonoglyph; sp, marginal sphincter musculature; t, tentacle; Scale bars: A, 40 mm; B, $20 \mathrm{~mm}$; C, H, $2 \mathrm{~mm}$; D, E, I, L, $0.5 \mathrm{~mm}$;, $10 \mathrm{~mm}$; G, $2.5 \mathrm{~mm}$;, $0.2 \mathrm{~mm}$; K, M, $0.25 \mathrm{~mm}$. 


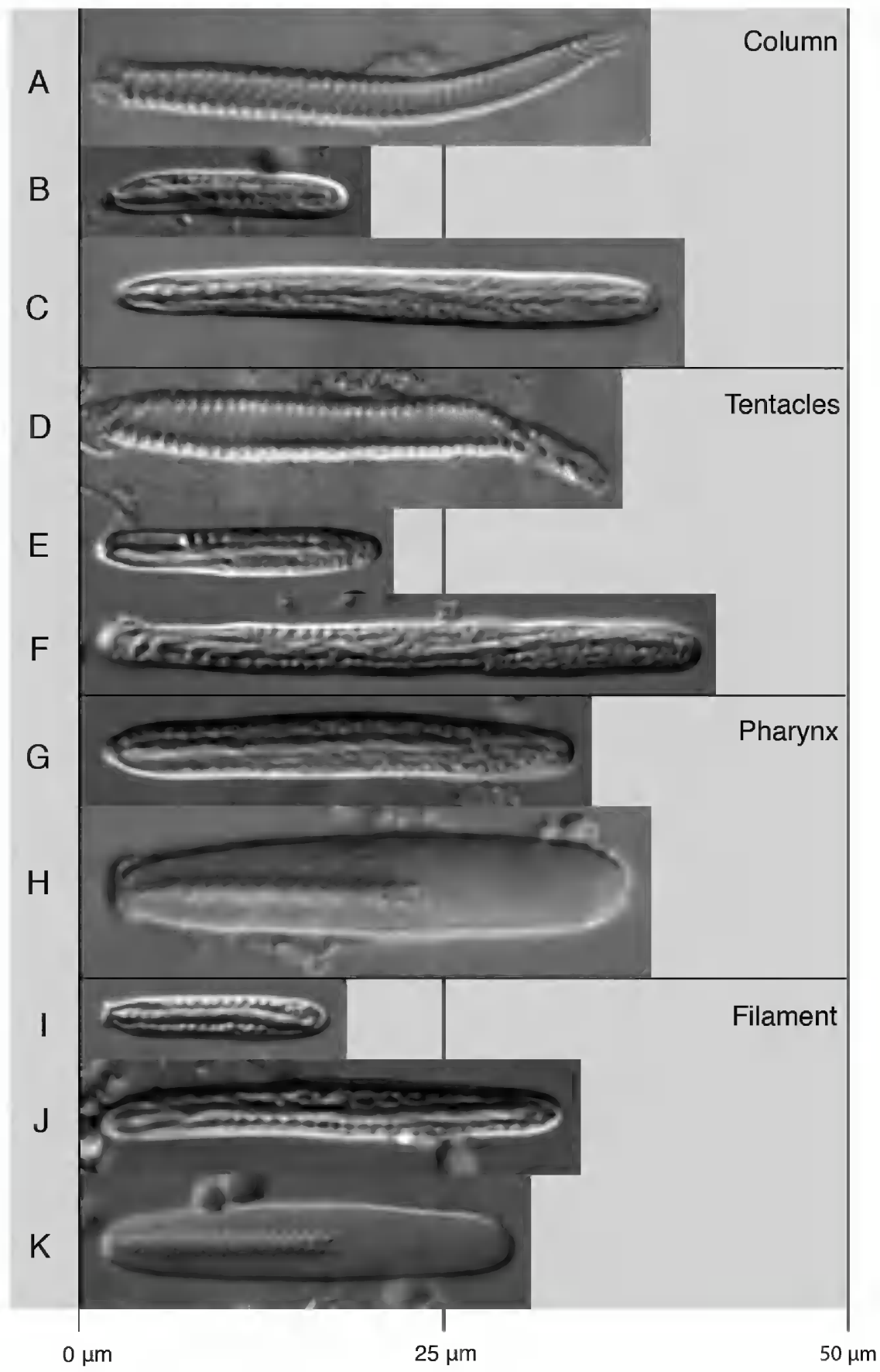

FIG. 6. Cnidom of Sicyonis erythrocephala (Pax, 1922): A, D, spirocyst; B, C, E, F, G, I, J, basitrich; H, K, p-mastigophore A. 
REMARKS: Our material is identified as a Sicyonis based on a combination of a mesogleal longitudinal musculature in the tentacles (absent in Tealidium Hertwig, 1882; Anthosactis Danielssen, 1890; Paranthus Andres, 1883; Bathydactylus Carlgren, 1928a; Antiparactis Verrill, 1899; Pseudoparactis Stephenson, 1920; Antholoba Hertwig, 1882), unequal development of mesenteries in a pair (absent in Pycnanthus McMurrich, 1893; Hormosoma Stephenson, 1918a; Cnidanthus Carlgren, 1927), absence of $b$-mastigophores in tentacles (present in Actinostola Verrill, 1883; Stomphia Gosse, 1859), and number and cycles of mesenteries and pseudotentacles present in Ophiodiscus Hertwig, 1882 (Carlgren, 1949; Fautin, 1984; Rodríguez et al., 2008; Eash-Loucks and Fautin, 2012). It can be further differentiated from Parasicyonis Carlgren, 1921, by the presence of filaments in fertile mesenteries (present in Parasicyonis; absent in S. erythrocephala) and number of perfect mesenteries (some mesenteries of fourth cycle perfect in Parasicyonis; no mesenteries of fourth cycle perfect in $S$. erythrocephala) (Carlgren, 1921, 1949; Rodríguez et al., 2008; Eash-Loucks and Fautin, 2012). From Synsicyonis Carlgren, 1921, our specimens can be differentiated by the number of cycles of mesenteries (four in Synsicyonis; up to six in Sicyonis and five in S. erythrocephala) and the fertility of the mesenteries (third cycle of mesenteries fertile in Synsicyonis; only fourth cycle of mesenteries fertile in S. erythrocephala) (Carlgren, 1921, 1949; Rodríguez et al., 2008).

Sicyonis is a deep-sea genus of poorly known species whose identification is difficult due to unknown variability in diagnostic morphological characters (Molodtsova et al., 2008). Despite these difficulties, our specimens agree with the description of the external and internal anatomy given by Carlgren (1927) for S. erythrocephala. Except for the size of the nematocysts in the tentacles and actinopharynx, which are closer to the measurements given by Carlgren (1939) than those from
Carlgren (1927), our specimens show only slight differences in the number of mesenteries described for S. erythrocephala: they have 68 pairs whereas Carlgren recorded 70 and 88 pairs (Carlgren 1927, 1939, respectively). The differences in number of mesenteries could be due to the different size of specimens or the difficulty in counting mesenteries in general, but especially in badly preserved deep-sea specimens. It is important to note that S. erythrocephala falls into a group within Actinostolidae that, in general, does not follow the Actinostola rule, even indistinctly (Sanamyan et al., 2015). This is seen in our specimens of $S$. erythrocephala in which small differences within a pair can be observed only in the histological sections (fig. 5G), but not in the dissections. Sicyonis erythrocephala can be differentiated from five of the species of the genus by features of the tentacles: development of the basal aboral thickening of the tentacles (present in S. erythrocephala; absent in of $S$. variabilis), basal aboral thickening projecting as large swollen bulb (absent in S. erythrocephala; present in S. tuberculata), number of tentacles (132 in S. erythrocephala; 144 in $S$. gossei; 200 in S. tubulifera), morphology of tentacles (wartlike in $S$. crassa; filiform in $S$. erythrocephala), and distribution of tentacles in oral disc (marginal in S. heliodiscus; outer half of oral disc in S. erythrocephala). Sicyonis erythrocephala can be further distinguished from the other species of the genus by the marginal sphincter musculature (well developed in S. hemisphaerica and S. sumatriensis; weak in S. erythrocephala) and its nature (alveolar proximally and distally in S. carey; reticular throughout in S. erythrocephala)

Superfamily Actinioidea Rafinesque, 1815

Family Actiniidae Rafinesque, 1815

Genus Bolocera Gosse, 1860

Diagnosis (modified from Carlgren, 1949; modifications in bold): Actiniidae with well- 
TABLE 2

Size ranges of the cnidae of Sicyonis erythrocephala (Pax, 1922)

Abbreviations and symbols: $\mathrm{SD}$, standard deviation; $N$, Total number of capsules measured; $S$, proportion of specimens in which each cnidae was found; F, frequency; +++, very common; ++ , common; + , rather common; -, rare.

\begin{tabular}{|c|c|c|c|c|c|}
\hline Categories & $\begin{array}{l}\text { Range of length and width of } \\
\text { capsules }(\mu \mathrm{m})\end{array}$ & Mean \pm SD & $N$ & $S$ & $\mathbf{F}$ \\
\hline \multicolumn{6}{|l|}{ Column } \\
\hline Spirocysts (A) & $25.3-67.9 \times 3.1-6.3$ & $49.1 \pm 11.3 \times 4.5 \pm 0.7$ & 57 & $2 / 2$ & +++ \\
\hline Basitrich I (B) & $16.4-22.8 \times 2.3-3.6$ & $18.1 \pm 1.3 \times 3.0 \pm 0.3$ & 34 & $2 / 2$ & ++ \\
\hline Basitrich II (C) & $23.5-64.5 \times 2.8-4.9$ & $36.2 \pm 7.1 \times 3.7 \pm 0.4$ & 41 & $2 / 2$ & ++ \\
\hline \multicolumn{6}{|l|}{ Tentacles } \\
\hline Spirocysts (D) & $27.7-66.3 \times 3.1-7.2$ & $47.8 \pm 8.4 \times 4.6 \pm 0.7$ & 102 & $2 / 2$ & +++ \\
\hline Basitrich I (E) & $15.1-20.3 \times 2.7-3.7$ & $17.6 \pm 1.0 \times 3.1 \pm 0.2$ & 40 & $2 / 2$ & ++ \\
\hline Basitrichs II (F) & $21.4-48.9 \times 2.9-4.0$ & $39.2 \pm 4.4 \times 3.4 \pm 0.3$ & 44 & $2 / 2$ & ++ \\
\hline Holotrichs & $12.2 \times 2.7$ & - & 1 & $1 / 2$ & - \\
\hline \multicolumn{6}{|l|}{ ACTINOPHARYNX } \\
\hline Basitrichs II (G) & $27.2-39.2 \times 3.1-5.4$ & $34.9 \pm 2.3 \times 3.9 \pm 0.4$ & 102 & $2 / 2$ & +++ \\
\hline$P$-mastigophores A $(\mathrm{H})$ & $23.1-32.3 \times 4.0-6.5$ & $27.4 \pm 1.7 \times 5.3 \pm 0.5$ & 67 & $2 / 2$ & +++ \\
\hline \multicolumn{6}{|l|}{ FILAMENT } \\
\hline Basitrichs I (I) & $13.7-21.9 \times 2.4-3.8$ & $16.7 \pm 1.8 \times 3.0 \pm 0.3$ & 82 & $2 / 2$ & +++ \\
\hline Basitrichs II (J) & $26.0-43.3 \times 2.9-5.1$ & $35.9 \pm 4.2 \times 3.9 \pm 0.5$ & 57 & $2 / 2$ & ++ \\
\hline$P$-mastigophores A (K) & $23.5-30.8 \times 4.0-5.7$ & $27.4 \pm 2.0 \times 5.0 \pm 0.4$ & 62 & $2 / 2$ & ++ \\
\hline
\end{tabular}

developed pedal disc. Column elongated, smooth. Endodermal marginal sphincter musculature diffuse. Tentacles long, hexamerously arranged on outer half of oral disc; each tentacle with an endodermal sphincter at its base, by the contraction of which it may be thrown off the longitudinal muscles ectodermal. Siphonoglyphs well developed. Perfect pairs of mesenteries more or less numerous, two pairs of directives. Retractors diffuse. Mesenteries not more numerous at margin than at limbus. Cnidom: spirocysts, basitrichs, $\boldsymbol{p}$-mastigophores $\mathbf{A}$.

Type SPecies: Actinia tuediae Johnston, 1832.

VALID SPECIES: Bolocera africana Pax, 1909; B. kensmithi Eash-Loucks and Fautin, 2012; B. kerguelensis Studer, 1879; B. maxima Carlgren, 1921; B. novergica Pax, 1909; B. pannosa McMur- rich, 1893; B. paucicornis Dunn, 1893; B. somaliensis Carlgren, 1928a; B. tuediae (Fautin, 2016).

\section{Bolocera kerguelensis Studer, 1879}

Figures 7-8, table

MATERIAL: MNRJ 8175 (1 specimen); locality: Ak. Ioffe Cruise 29, Shirshov st. 2184-5, Superestação 1, Sta. 201, series \#1030, Mid-Atlantic Ridge, $29^{\circ} 27.12^{\prime} \mathrm{S} 10^{\circ} 08.72^{\prime} \mathrm{W}$, collected on 20 November 2009 by MAR-ECO \#36066 (4120 m). MNRJ 8181 (1 specimen); locality: Ak. Ioffe Cruise 29, Shirshov st. 2184-5, Superestação 7, Sta. 201, series \#1030, Mid-Atlantic Ridge, $29^{\circ} 27.12^{\prime} \mathrm{S} 10^{\circ} 08.72^{\prime} \mathrm{W}$, collected on 20 November 2009 by MAR-ECO \#36038 (4120 m). 
MATERIAL EXAMINED: Bolocera kerguelensis: AMNH 4653 (5 specimens); locality: ANT XIX/5 Cruise, LAMPOS Program, RV Polastern, Sta. 61/150, Burdwood/Namuncurá Bank, $54^{\circ} 30.22^{\prime} \mathrm{S} 56^{\circ} 08.20^{\prime} \mathrm{W}$, collected on 6 April 2002 by E. Rodríguez ( $286 \mathrm{~m})$. AMNH 4912 (1 specimen); locality: ANT XXI/2 Cruise, BENDEX Program, RV Polastern, Sta. PS65/1091, Antarctica, North Kapp Norvegia, 7047.88' $S 11^{\circ} 21.56^{\prime} \mathrm{W}$, collected on 10 December 2003 by E. Rodríguez (1488 m).

External anatomy (fig. 7): Pedal disc well developed, circular, with well-marked limbus, 49-62 $\mathrm{mm}$ in diameter in preserved specimens. Column funnel shaped, short, cylindrical, smooth, not divided into regions, much wider than pedal disc; margin not tentaculate. Column beige, $45-49 \mathrm{~mm}$ in diameter and $35-44 \mathrm{~mm}$ in length in preserved specimens. Oral disc circular, wide, nonretractile, same color as column, with large central mouth with two visible siphonoglyphs; specimens with everted actinopharynx due to sampling process (fig. 7D); $44-62 \mathrm{~mm}$ in diameter in preserved specimens. Tentacles deciduous with basal marginal endodermal sphincter, numerous, smooth, thick, with longitudinal ridges, $170-182$ in 6 cycles $(6+6+12+24+48+n)$ in most of oral disc (fig. $7 \mathrm{D})$; many tentacles autotomized and detached from oral disc of preserved specimens, their absence marked by holes in oral disc (fig. 7D). Inner and outer tentacles of similar or dissimilar size due to regeneration (fig. 7D); longest tentacle up to $50 \mathrm{~mm}$ in preserved specimens.

INTERNAL ANATOMY AND HISTOLOGY (fig. 7): Body wall thickness uniform throughout column: gastrodermis (316-537 $\mu \mathrm{m})$, mesoglea (314-595 $\mu \mathrm{m}$ ), and epidermis (287-542 $\mu \mathrm{m}$ ) (fig. 7B). Marginal sphincter endodermal musculature diffuse (fig. 7C). Longitudinal musculature of tentacles ectodermal.

Mesenteries in five cycles $(6+6+12+24+n=$ 90-93) spanning most of body length (fig. 7E, F): mesenteries of first and second cycles perfect, fertile, except for two pairs of sterile directives (fig. 7E); each pair of directives associated with one siphonoglyph; third cycle mostly imperfect, sometimes perfect, fertile (fig. 7F, G); fourth and fifth cycles imperfect (fig. 7G, H and fig. 7G, I, J, respectively). Mesenteries of first to fourth cycles with filaments (fig. 7F, G); those of fifth cycle without filaments (fig. 7F, H). Same number of mesenteries distally and proximally. All specimens collected in November males; major axis of spermatic cysts 113-405 $\mu \mathrm{m}$ (fig. 7G, H). Species inferred gonochoric. Retractors of all mesenteries strong, diffuse (fig. 7F-H, I); parietobasilar musculature in all mesenteries (fig. $7 \mathrm{~F}-\mathrm{L}$ ), but particularly strong and well developed with free mesogleal flap in mesenteries of first to fourth cycles (fig. 7F, G, K); mesenteries of fifth cycle with weak parietobasilar musculature (fig. $7 \mathrm{~K}$ ).

CNIDOM (fig. 8): Spirocysts, basitrichs, $b$-mastigophores, $p$-mastigophores A. See figure 8 and table 3 for size and distribution.

Distribution AND NATURAL HISTORY: The two specimens of Bolocera kerguelensis were collected in the area west of the Mid-Atlantic Ridge in the South Atlantic at $4120 \mathrm{~m}$. The specimens were not attached to any solid substrate, which suggests they might rest loosely on the sediment as noted by other authors (Dunn and Bakus, 1977; Riemann-Zürneck, 1979). Our new records extend the geographic range of the species-which is widespread in the Southern Ocean (plus doubtful records in the South African coast: see Rodríguez and López-González, 2013) and on both sides of South America (Dunn, 1983; Riemann-Zürneck, 1986; Rodríguez and López-González, 2013) — to include the area surrounding the SMAR region above the $35^{\circ} \mathrm{S}$ parallel (fig. 1). The closest previous record to the Mid-Atlantic Ridge is from the area around the Traversay Islands (Dunn, 1983) but at a much shallower depth (1532-1590 m). We also extend slightly the bathymetric range of this eurybathic species known from the continental shelf to bathyal depths in the Antarctic and sub-Antarctic regions (Rodríguez et al., 2007; Rodríguez and López-González, 2013) from $45-3947 \mathrm{~m}$ to $45-4120 \mathrm{~m}$. These new records represent a third instance of a deep-sea 

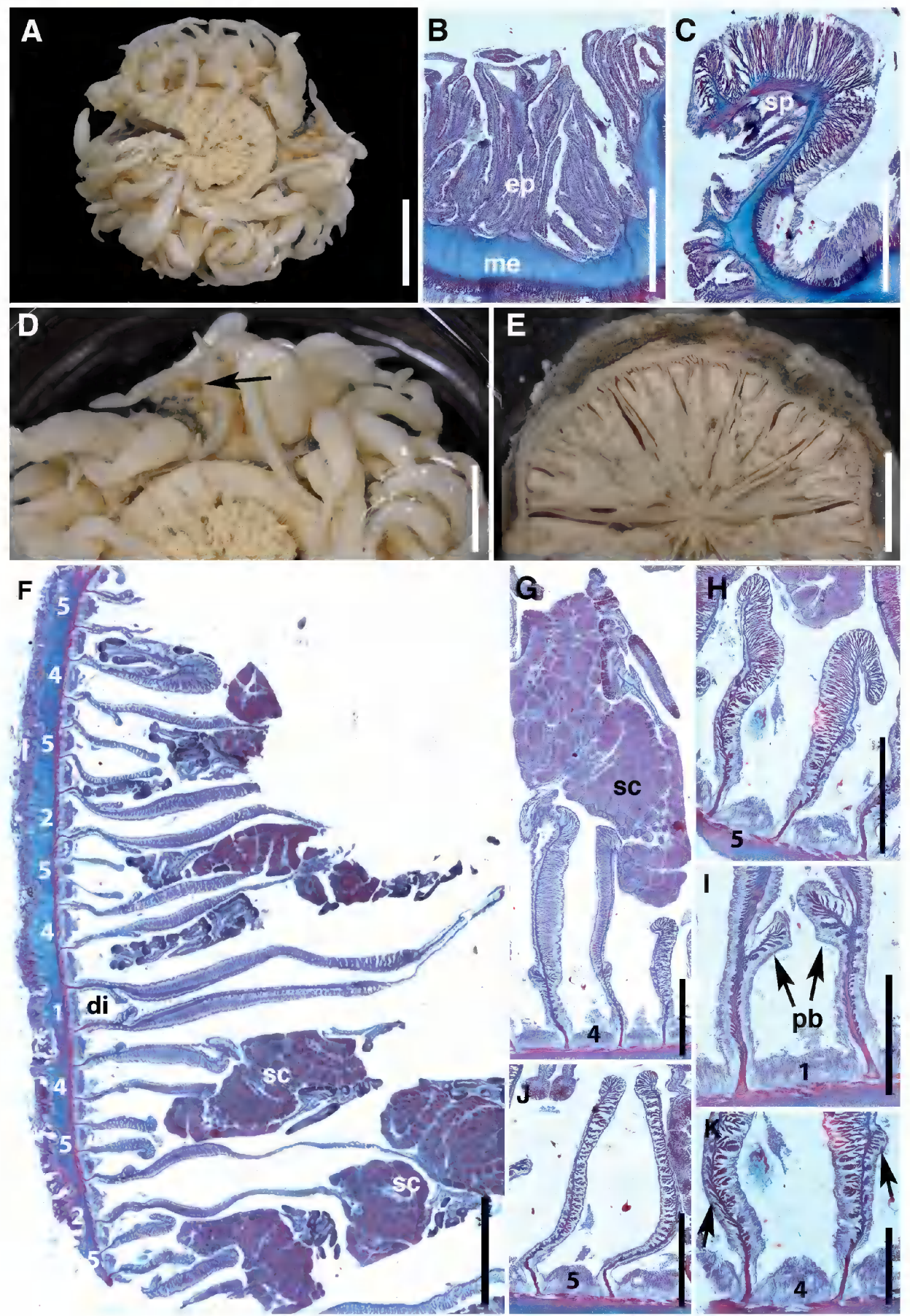
anemone found in Antarctica and sub-Antarctica whose geographic range extends beyond the Southern Ocean, the others being Galatheanthemum profundale Carlgren, 1956, and Liponema multiporum Hertwig, 1882 (see Rodríguez et al., 2007).

REMARKs: The differentiation of species in the genus Bolocera based on morphology or cnidae is difficult, particularly for species recorded for the South Atlantic (Rodríguez and LópezGonzález, 2013). The circumscription of the genus Bolocera in the South Atlantic and Antarctic region has varied from two species-either $B$. kerguelensis and B. tuediae occidua (RiemannZürneck, 1980) or B. kerguelensis and B. paucicornis Dunn, 1983-to only one, B. tuediae kerguelensis (Riemann-Zürneck, 1986). However, because Rodríguez and López-González (2013) found inconsistencies in the morphological and cnidae characters used by Riemann-Zürneck (1980) and Dunn (1983) to differentiate Bolocera species in the Southern Ocean, the authors synonymized all species under B. kerguelensis until further studies (Rodríguez and López-González, 2013). For this reason, until a thorough morphological and molecular revision of the genus is carried out, we identify our specimens as B. kerguelensis as the morphology of our specimens generally agree with previous descriptions of that species (e.g., Riemann-Zürneck, 1980; Rodríguez and López-González, 2013). One exception is the fertility of the mesenteries of the fourth cycle, which was previously described as sterile (Rodríguez and López-González, 2013), but they were fertile in our specimens (fig. 7F, G). Similarly, the cnidae of specimens examined in this study agrees with the cnidom given by Rodríguez and López-González (2013) for B. kerguelensis from Antarctica, except for our finding of $p$-mastigophores $\mathrm{A}$ in the column (fig. 8C) and nematocysts we identified as $b$-mastigophores in the filament of our specimens (fig. 8L), both of which have never been described in B. kerguelensis. It is possible these two nematocysts were not found in previous studies due to their scarcity, particularly of the $p$-mastigophores $\mathrm{A}$ of the column, but their presence has been confirmed in histological sections. The $b$-mastigophores found in the filaments are similar to those found in other actiniids (e.g., Epiactis Verrill, 1869a, Glyphoperidium Roule, 1909, Isosicyonis Carlgren, 1927).

\section{Genus Isotealia Carlgren, 1899}

Diagnosis (modified from Carlgren, 1949; modifications in bold): Actiniidae with welldeveloped pedal disc. Column smooth, divisible into scapus and scapulus. Scapus with easily deciduous cuticle. Margin with perforated pseudoacrorhagi with basitrichs. Endodermal marginal sphincter well developed, circumscribed. Tentacles short, hexamerously arranged, inner longer than outer ones. Two siphonoglyphs. Approximately same number of mesenteries proximally and distally. Retractors strong, diffuse. Parietobasilar and basilar musculature distinct. Mesenteries of first and second cycle sterile. Cnidom: spirocysts, basitrichs, p-mastigophores A.

FIG. 7. External and internal anatomy and histology of Bolocera kerguelensis Studer, 1879. A, Oral view of the specimen; B, detail of the body wall and tissue layers; C, longitudinal section through distal column and endodermal musculature of sphincter; $\mathbf{D}$, detail of oral disc and long tentacles, some of which autotomized (arrow); note longitudinal ridges of tentacles; E, cross section through proximal column and cycles of mesenteries; F, histological cross section through proximal column and cycles of mesenteries (indicated by numbers); note gametogenic tissue on third and fourth cycles; G, detail of imperfect, fertile fourth cycle of mesenteries; $\mathbf{H}$, detail of imperfect, sterile fifth cycle of mesenteries; $\mathbf{I}$, detail of parietobasilar musculature on first cycle of directive mesenteries; $\mathbf{J}$, detail of retractor of fifth cycle of mesenteries; $\mathbf{K}$, detail of parietobasilar of fourth cycle of mesenteries (arrows). Abbreviations: di, directive pair of mesenteries; ep, epidermis; me, mesoglea; sc, spermatic cysts; sp, marginal sphincter musculature; pb, parietobasilar musculature. Scale bars: A, $20 \mathrm{~mm}$; B, C, F-J, $1 \mathrm{~mm}$; D, E, $10 \mathrm{~mm}$; K, $0.5 \mathrm{~mm}$. 


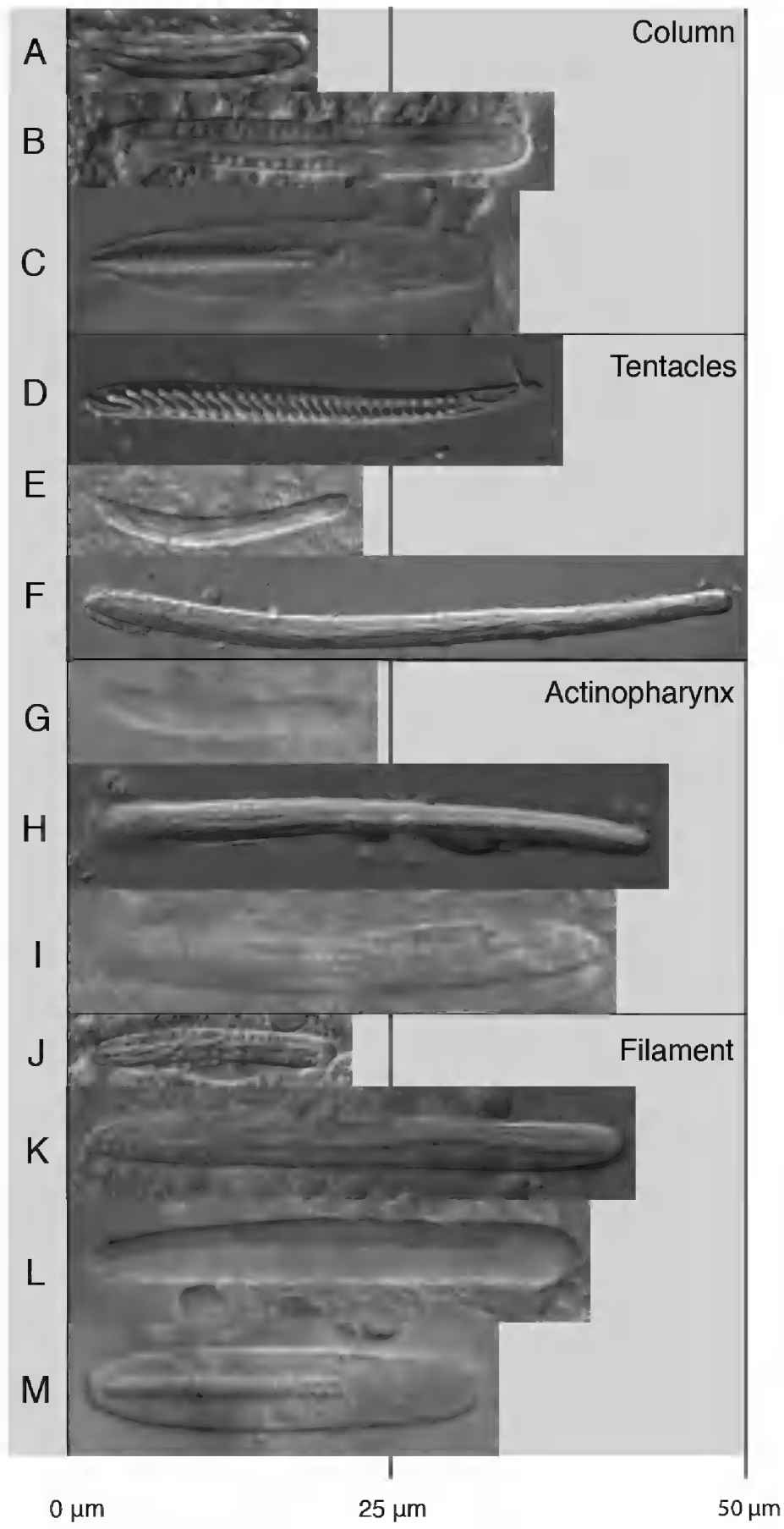

FIG. 8. Cnidom of Bolocera kerguelensis Studer, 1879: A, B, E, F, G, H, J, K, basitrich; D, spirocyst; C, I, M, p-mastigophore A; L, b-mastigophore (?). 


\section{TABLE 3}

Size ranges of the cnidae of Bolocera kerguelensis Studer, 1879

Abbreviations and symbols: SD, standard deviation; $N$, Total number of capsules measured; $S$, proportion of specimens in which each cnidae was found; F, frequency; +++, very common; ++ , common; +, rather common; -, rare.

\begin{tabular}{|c|c|c|c|c|c|}
\hline Categories & $\begin{array}{l}\text { Range of length and width of } \\
\text { capsules }(\mu \mathrm{m})\end{array}$ & Mean \pm SD & $N$ & S & $\mathbf{F}$ \\
\hline \multicolumn{6}{|l|}{ Column } \\
\hline Basitrich I (A) & $15.9-22.2 \times 2.1-3.8$ & $18.9 \pm 1.6 \times 3.1 \pm 0.4$ & 81 & $2 / 2$ & ++ \\
\hline Basitrich II (B) & $29.1-50.6 \times 3.4-6.1$ & $36.3 \pm 4.4 \times 4.2 \pm 0.5$ & 96 & $2 / 2$ & +++ \\
\hline$P$-mastigophores A (C) & $26.2-31.0 \times 5.0-6.2$ & $28.2 \pm 1.1 \times 5.5 \pm 1.8$ & 61 & $2 / 2$ & ++ \\
\hline \multicolumn{6}{|l|}{ Tentacles } \\
\hline Spirocysts (D) & $23.6-71.7 \times 4.3-9.8$ & $42.2 \pm 7.1 \times 6.4 \pm 1.8$ & 110 & $2 / 2$ & +++ \\
\hline Basitrichs I (E) & $21.0-37.2 \times 2.6-3.8$ & $26.8 \pm 2.6 \times 3.2 \pm 0.5$ & 65 & $2 / 2$ & ++ \\
\hline Basitrichs II (F) & $52.4-87.9 \times 3.4-5.8$ & $63.2 \pm 8.1 \times 4.6 \pm 1.1$ & 80 & $2 / 2$ & +++ \\
\hline \multicolumn{6}{|l|}{ ACTINOPHARYNX } \\
\hline Basitrichs I (G) & $23.5-41.0 \times 2.4-3.9$ & $29.2 \pm 4.2 \times 3.1 \pm 0.7$ & 48 & $2 / 2$ & ++ \\
\hline Basitrichs II (H) & $43.8-67.2 \times 3.5-5.8$ & $54.5 \pm 8.2 \times 4.8 \pm 0.9$ & 92 & $2 / 2$ & +++ \\
\hline$P$-mastigophore A (I) & $24.4-41.0 \times 3.5-6.0$ & $28.1 \pm 3.2 \times 4.9 \pm 1.0$ & 51 & $2 / 2$ & ++ \\
\hline \multicolumn{6}{|l|}{ Filament } \\
\hline Basitrichs I (J) & $20.4-27.3 \times 2.7-3.8$ & $23.2 \pm 1.6 \times 3.3 \pm 0.3$ & 98 & $2 / 2$ & +++ \\
\hline Basitrichs II (K) & $39.0-54.0 \times 3.2-5.9$ & $49.4 \pm 3.4 \times 4.5 \pm 0.5$ & 52 & $2 / 2$ & ++ \\
\hline$B$-mastigophores (L) & $37.9-44.8 \times 4.3-5.5$ & $42.0 \pm 2.0 \times 4.8 \pm 0.4$ & 45 & $2 / 2$ & + \\
\hline$P$-mastigophores A (M) & $24.4-31.6 \times 4.6-6.3$ & $28.3 \pm 1.9 \times 5.5 \pm 0.5$ & 52 & $2 / 2$ & ++ \\
\hline
\end{tabular}

TYPES SPECIES: Isotealia antarctica Carlgren, 1899, by original designation.

VALID SPECIES: Isotealia antarctica; I. dubia (Wassilieff, 1908) (Fautin, 2016).

\section{Isotealia antarctica Carlgren, 1899}

Figures 9-10, table 4

MATERIAL: MNRJ 8162 (2 specimens); locality: Ak. Ioffe Cruise 29, Shirshov St. 2184-5, Superestação 2, series \#1040, Sta. 201, MidAtlantic Ridge, $32^{\circ} 50.15^{\prime} \mathrm{S} 14^{\circ} 07.0^{\prime} \mathrm{W}$, collected on 22 November 2009 by MAR-ECO \#38152 (1401 m).

MATERIAL EXAMINED: Isotealia cf. antarctica USNM 42671 (1 specimen); locality: R/V Alba- tross, Sta. 2767, South Atlantic Ocean, Blanca Bay, $40^{\circ} 03^{\prime} \mathrm{S} 58^{\circ} 55.99^{\prime} \mathrm{W}$, collected on 13 January 1888 by United States Fish Commission ( $95 \mathrm{~m}$ ).

External anatomy (fig. 9): Pedal disc flat, circular, adherent, slightly broader than column, with visible mesenteries insertions as dark lines; up to $84 \mathrm{~mm}$ in diameter in preserved specimens (fig. 9A). Column cylindrical, smooth, divisible into scapus and scapulus (fig. 9A). Margin with 48 pseudoacrorhagi with bastrichs; small fosse (fig. 9B). Column beige in preserved specimens with deciduous cuticle covering most of scapus, including pseudoacrorhagi (fig. 9A, B). Column up to $47 \mathrm{~mm}$ in length and $66 \mathrm{~mm}$ in diameter in preserved specimens. Oral disc partly contracted in preserved specimens, narrower than column diameter, with central, large mouth and 

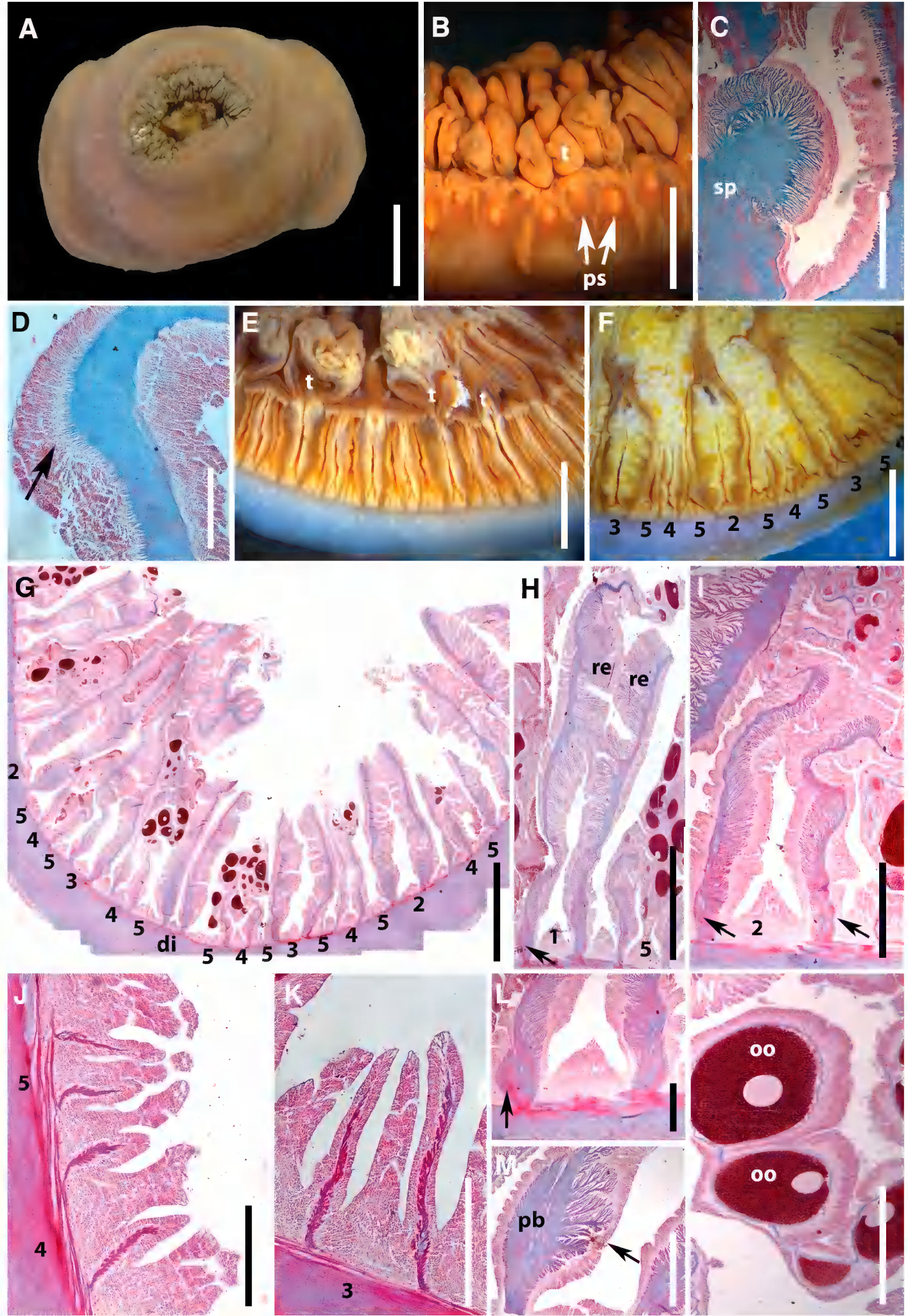


\section{TABLE 4}

\section{Size ranges of the cnidae of Isotealia antarctica Carlgren, 1899}

Abbreviations and symbols: SD, standard deviation; $N$, Total number of capsules measured; $\mathrm{S}$, proportion of specimens in which each cnidae was found; $\mathrm{F}$, frequency; +++, very common; ++ , common; +, rather common; -, rare.

\begin{tabular}{|c|c|c|c|c|c|}
\hline Categories & $\begin{array}{l}\text { Range of length and width of } \\
\text { capsules }(\mu \mathrm{m})\end{array}$ & Mean \pm SD & $\mathrm{S}$ & $N$ & $\mathbf{F}$ \\
\hline \multicolumn{6}{|l|}{ Column } \\
\hline Basitrich (A) & $9.3-25.1 \times 2.0-3.0$ & $21.6 \pm 2.1 \times 2.5 \pm 0.2$ & 122 & $2 / 2$ & +++ \\
\hline$P$-mastigophores A (B) & $18.3-25.0 \times 3.1-4.5$ & $22.0 \pm 1.5 \times 3.4 \pm 0.8$ & 65 & $2 / 2$ & ++ \\
\hline \multicolumn{6}{|l|}{ Tentacles } \\
\hline Gracile spirocysts (C) & $18.2-35.7 \times 2.6-5.5$ & $27.3 \pm 4.1 \times 3.8 \pm 0.6$ & 122 & $2 / 2$ & ++ \\
\hline Basitrich (D) & $21.0-30.0 \times 1.9-3.1$ & $26.0 \pm 1.7 \times 2.4 \pm 0.3$ & 116 & $2 / 2$ & ++ \\
\hline \multicolumn{6}{|l|}{ ACTINOPHARYNX } \\
\hline Basitrichs I (E) & $17.5-25.8 \times .9-3.1$ & $20.2 \pm 1.1 \times 2.3 \pm 0.6$ & 61 & $2 / 2$ & ++ \\
\hline Basitrichs II (F) & $26.3-39.0 \times 2.2-3.4$ & $34.4 \pm 2.0 \times 2.7 \pm 0.216$ & 71 & $2 / 2$ & +++ \\
\hline$P$-mastigophores A (G) & $20.4-29.5 \times 4.8-5.9$ & $24.6 \pm 2.3 \times 5.0 \pm 0.7$ & 55 & $2 / 2$ & ++ \\
\hline \multicolumn{6}{|l|}{ Filament } \\
\hline Basitrich I (H) & $12.8-25.3 \times 2.4-3.4$ & $19.2 \pm 1.0 \times 3.0 \pm 0.4$ & 83 & $2 / 2$ & +++ \\
\hline Basitrichs II (I) & $20.3-28.0 \times 3.2-4.9$ & $25.2 \pm 0.9 \times 3.8 \pm 1.0$ & 52 & $2 / 2$ & ++ \\
\hline$P$-mastigophores A (J) & $20.7-27.5 \times 4.4-6.2$ & $23.4 \pm 2.1 \times 4.9 \pm 0.4$ & 68 & $2 / 2$ & ++ \\
\hline
\end{tabular}

FIG. 9. External and internal anatomy and histology of Isotealia antarctica Carlgren, 1899. A, Oral view of preserved specimen; B, detail of distal column with pseudoacrorhagi and tentacles; C, longitudinal section through distal column showing endodermal sphincter musculature; D, cross section through tentacle and ectodermal longitudinal :musculature (arrow); E, cross section through oral disc and cycles of mesenteries and tentacles; F, cross section through midcolumn and cycles of mesenteries (numbers); $\mathbf{G}$, histological cross section through midcolumn and cycles of mesenteries (numbers); $\mathbf{H}$, detail of pair of mesenteries of first cycle with strong, diffuse retractor musculature and gametogenic tissue; note the parietobasilar with flap (arrow); I, detail of a pair of mesenteries of second cycle with strong, diffuse retractor musculature and strong parietobasilar musculature with flap (arrow); J, Pairs of third and fourth cycles with weak retractor and parietobasilar musculatures; $\mathbf{K}$, detail of pair of mesenteries of third cycle; $\mathbf{L}$, detail of parietobasilar musculature with separate flap in a pair of mesenteries of second cycle; $\mathbf{M}$, detail of parietobasilar musculature in a mesentery of first cycle; note larva (arrow); $\mathbf{N}$, detail of oocytes in various developmental stages. Abbreviations: t, tentacle; oo, oocytes; pb, parietobasilar musculature; ps, pseudoacrorhagi; sp, marginal sphincter musculature. Scale bars: A, $20 \mathrm{~mm}$; B, E-G, $5 \mathrm{~mm}$; C, I, M, $1 \mathrm{~mm}$; D, J, $0.3 \mathrm{~mm} ; \mathbf{H}, 2.5 \mathrm{~mm} ; \mathbf{K}, 0.4 \mathrm{~mm}$. L, $0.5 \mathrm{~mm}$; N, $0.6 \mathrm{~mm}$. 


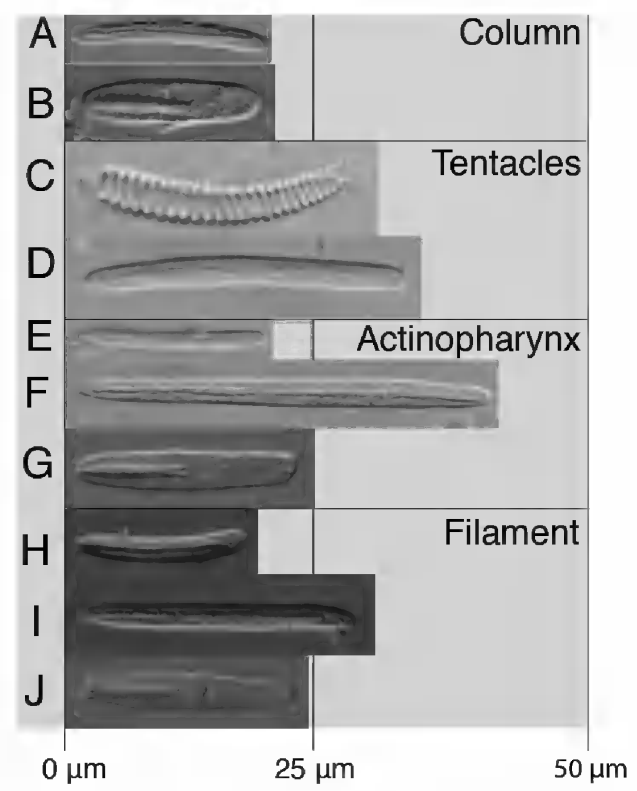

FIG. 10. Cnidom of Isotealia antarctica Carlgren, 1899: A, D, E, F, H, I, basitrich; B, G, J, p-mastigophore A; C, spirocyst.

short tentacles visible (fig. 9A); oral disc $33 \mathrm{~mm}$ in diameter in preserved specimens (fig. 9A). Tentacles 170-182, smooth, short, beige or olive green, with no markings (fig. 9B), in 6 cycles $(6+6+12+24+48+[74-86)])$ in outer half of oral disc (fig. 9A).

INTERNAL ANATOMY AND HISTOLOGY (fig. 9): Marginal sphincter musculature endodermal, circumscribed (fig. 9C). Actinopharynx short, longitudinally sulcated throughout. Longitudinal musculature of tentacles ectodermal (fig. 9D). Mesenteries hexamerously arranged in five cycles $(6+6+12+24+[37-43]=$ 85-91 pairs), more mesenteries proximally than distally (fig. 9E, F): first and second cycles perfect, sterile, including two pairs of directives, each associated to one siphonoglyph; third cycle perfect, fertile, with filaments (fig. 9G, H); fourth cycle imperfect, fertile, with filaments (figs. 9G, I); fifth cycle imperfect, sterile, without filaments (figs. 9J, $\mathrm{K})$. Retractors of first to third cycles strong, diffuse (figs. 9G-I) and parietobasilar musculature well developed, with thick mesogleal flap (figs. 9L, M); mesenteries of fourth and fifth cycles with weak retractors and parietobasilar musculature no developed (figs. 9J, K). Basilar musculature strong. All examined specimens collected in November female (figs. 9G-I, N), major axis of oocytes 117-919 $\mu \mathrm{m}$ in diameter. Species inferred gonochoric.

CNidom (fig. 10): Spirocysts, basitrichs, p-mastigophores A. See figure 10 and table 4 for size and distribution.

DistribUtion AND NATURAL HISTORY: Isotealia antarctica is currently an Antarctic and sub-Antarctic species found off the coast of Argentina and Chile (McMurrich, 1893; Carlgren, 1959; Häusserman and Försterra, 2005) and as far north as the Rio de La Plata (Riemann-Zürneck, 1980). Rieman-Zürneck (1980) concluded that $I$. antarctica inhabits a corridor parallel to the continental shelf between $34^{\circ}$ $\mathrm{S}-50^{\circ} \mathrm{S}$ due to a low tolerance of temperature fluctuations. More recently, Rodríguez and López-González (2013) extended the geographic range of $I$. antarctica to Bouvet Island, in the southeast of Antarctica. Here we further 
extend the range of $I$. antarctica in the South Atlantic to the area around the south MidAtlantic Ridge (fig. 1). We also extend the bathymetric range of $I$. antarctica, which has been found in the continental shelf and bathyal depths from 25-600 m (Rodríguez and LópezGonzález, 2013) to $1401 \mathrm{~m}$. Our specimens were not attached to any substrate, unlike the specimens collected on solitary corals or snail shells by Riemann-Zürneck (1980).

Remarks: According to Riemann-Zürneck (1980), most specimens identified as I. antarctica (Carlgren, 1927) were poorly preserved and thus their distribution in Antarctica, Patagonia, and Chile needs confirmation. Records of $I$. antarctica in ecological studies in the Ross Sea (e.g., Dayton et al., 1974; Amsler et al., 1999) also need to be verified (Rodríguez and López-González, 2013). Furthermore, the specimen identified by Pax (1922) in the South Shetland Islands was identified by Carlgren (1927) as Telianthus inciertus Carlgren, 1927. The specimens of I. antarctica examined in this study agree morphologically with previous descriptions for the species (e.g., Carlgren, 1927; Riemann-Zürneck, 1980; Rodríguez and López-González, 2013). Our specimens were all female with large oocytes, even larger than those reported by Riemann-Zürneck (1980), i.e., $800 \mu \mathrm{m}$, but unlike Riemann-Zürneck (1980), we found no gametogenic tissue on pairs of the fifth cycle. In addition, we did not find some pairs of fourth cycle perfect as did Rodríguez and López-González (2013). Our cnidae measurements agree with those given by Riemann-Zürneck (1980), except for our finding of $p$-mastigophores $\mathrm{A}$ in the column of our specimens, which were not found by Riemann-Zürneck (1980) or Rodríguez and López-González (2013) in Antarctic specimens. On the other hand, the small basitrichs in the tentacles and $b$-mastigophores in the filaments found by Rodríguez and López-González (2013) were not found in our specimens. It is possible these differences are due to variability between populations and influence of local conditions (Rodríguez and López-González, 2013).
Superfamily Metridioidea Carlgren, 1893

Family Actinoscyphiidae Stephenson, 1920

Genus Actinoscyphia Stephenson, 1920

Diagnosis (modified from Carlgren, 1949; modifications in bold): Actinoscyphiidae with pedal disc never flat, sometimes very small, often on worm tubes or sponge spicules. Column thick to very thick, smooth, of gelatinous consistency. Tentacles in two cycles at margin of wide oral disc; tentacles with mesogleal basal aboral thickenings. Oral disc wide, lobed, sometimes bilobed. Longitudinal muscles of tentacles and radial muscles of oral disc ectodermal, sometimes mesoectodermal. Mesogleal sphincter musculature weak. Siphonoglyphs well developed. Mesenteries more numerous than tentacles. Six pairs of perfect and sterile mesenteries with diffuse retractors. All mesenteries thin, delicate, with weak, diffuse retractors. Cnidom: spirocysts, basitrichs, $\boldsymbol{p}$-mastigophores B1, and holotrichs.

TyPe sPecies: Actinernus saginata Verrill, 1882 , by original designation.

VAlid SPECIES: Actinoscyphia saginata; A. aurelia (Stephenson, 1918b); A. plebeia (McMurrich, 1893); A. groendyki Eash-Loucks and Fautin, 2012; (?) A. verrilli (Gravier, 1918) (Fautin, 2016).

\section{Actinoscyphia saginata (Verrill, 1882)}

Figures 11-12, table 5

MATERIAL: MNRJ 4223 (1 specimen); locality: REVIZEE Bahia 2, Sta. ZO522, sector 2, dredging 58, Southwestern Atlantic, Brazil, off the coast of Espirito Santo (ES), $21^{\circ} 15.22^{\prime} \mathrm{S}$ $39^{\circ} 53.05^{\prime} \mathrm{W}$, collected on 8 July 2000 by R/V Thalassa (1694 m). MNRJ 4224 (1 specimen); locality: REVIZEE Bahia 2, Sta. ZO527, sector 1, dredging 33, Southwestern Atlantic, Brazil, off the coast of Espirito Santo (ES), $20^{\circ} 02.23^{\prime} \mathrm{S}$ $39^{\circ} 23.62^{\prime} \mathrm{W}$, collected on 29 June 2000 by R/V Thalassa (1402 m). MNRJ 4226 (1 specimen); locality: REVIZEE Bahia 2, Sta. EO525, sector 1, dredging 31, Southwestern Atlantic, Brazil, off 

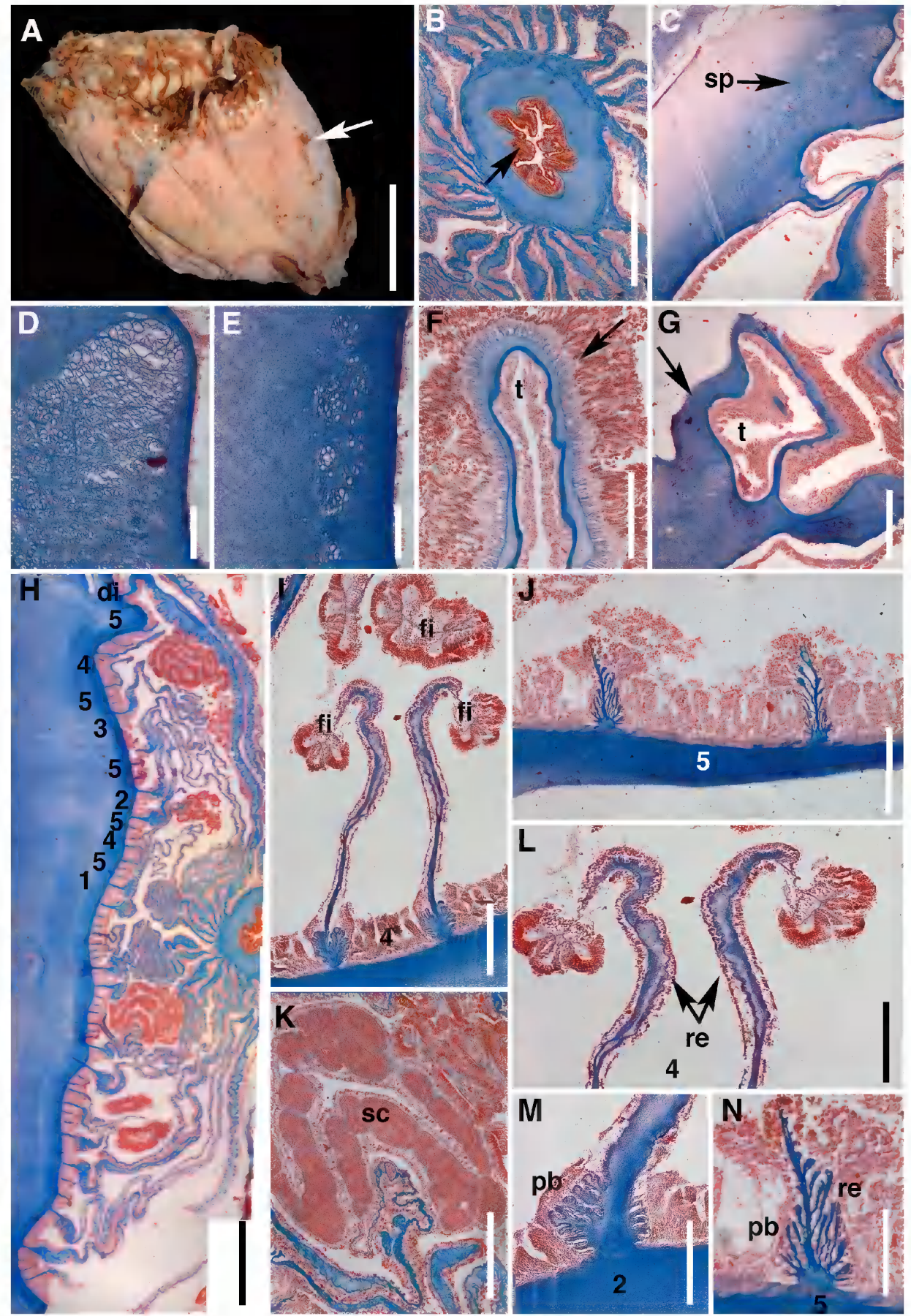
the coast of Espirito Santo (ES), $20^{\circ} 10.42^{\prime} \mathrm{S}$ $38^{\circ} 40.42^{\prime} \mathrm{W}$, collected on 28 June 2000 by R/V Thalassa (1639 m).

Material eXAmINeD: Actinoscyphia saginata: ZMUC ANT-000014 (1 specimen; syntype); locality: Ingolf Expedition, Sta. ING032, Arctic Ocean, Davis Strait, $66^{\circ} 35.0^{\prime} \mathrm{S} 56^{\circ} 38.0^{\prime} \mathrm{W}$, collected 11 July 1896 (599 m). USNM 78477 (3 specimens); locality: Northern Gulf of Mexico Continental Slope Expedition (NGOMCS), Cruise, IV, Sta. WC-9, R/V Citation, North Atlantic Ocean, northern Gulf of Mexico off Louisiana, $27^{\circ} 42.79^{\prime} \mathrm{S} 91^{\circ} 15.28^{\prime} \mathrm{W}$, collected on 23 May 1985 (695-807 m). USNM 079597 (1 specimen); locality: northern Gulf of Mexico Continental Slope Expedition (NGOMCS), Cruise, III, Sta. C11, R/V Gyre, northern Gulf of Mexico off Louisiana, $27^{\circ} 13.69^{\prime} \mathrm{S} 89^{\circ} 36.80^{\prime} \mathrm{W}$, collected on 8 December 1984 (2063-2085 m). Actinoscyphia plebeia: AMNH 4080 (14 specimens); locality: ANT XIX/3 Cruise, ANDEEP I Program, R/V Polarstern, Sta. PS61/114-10, Southern Ocean, Drake Passage, 61 $43.7^{\prime} \mathrm{S}$ $60^{\circ} 42.62^{\prime} \mathrm{W}$, collected on 19 February 2002 by Mercedes Conradi (2853-2856 m).

External anatomy (fig. 11): Animal irregularly shaped (fig. 11A). Pedal disc well developed, elongate, perpendicular to directive axis, tubular, wrapped around cylindrical substrate, with golden-brown chitinous material (fig. 11A, B); 88-142 $\mathrm{mm}$ in diameter in preserved specimens. Column irregularly shaped, not divisible into regions, stiff, smooth, mostly without epidermis and light-pink mesoglea exposed (fig. 11A); 19-57 $\mathrm{mm}$ in length and $52-92 \mathrm{~mm}$ in preserved specimens. Brown-red epidermis in parts of column (fig. 11A) and oral disc. Oral disc wide, irregularly shaped, folding on itself, but not bilobed (fig. 11A), with large central mouth; 34-62 $\mathrm{mm}$ in diameter in preserved specimens. Tentacles brown-red, slender, long, marginal, with beige, mesogleal basal aboral thickenings (fig. 11A); 140-152 in two marginal cycles (fig. 11A); outer tentacles longer than inner ones, longest tentacle up to $25 \mathrm{~mm}$ in preserved specimens.

INTERNAL ANATOMY AND HISTOLOGY (fig. 11): Body wall thick throughout column with mesoglea $(306-526 \mu \mathrm{m})$ much thicker than gastrodermis $(60-172 \mu \mathrm{m})$, and epidermis (69-237 $\mu \mathrm{m})$; mesoglea less thick proximally. Marginal sphincter musculature mesogleal, weak and diffuse without tendency for stratification, wider marginally and thinner proximally closer to gastrodermis (fig. 11C): all alveoli nonpigmented, larger and reticular distally (fig. 11D), smaller and scattered proximally (fig. 11E). Longitudinal musculature of tentacles ectodermal but less developed in aboral side (fig. 11F); mesogleal basal aboral thickenings in tentacles (fig. 11G).

Mesenteries hexamerously arranged in five cycles $(6+6+12+24+n=72-80$ pairs $)$ on entire body length: mesenteries of first and second cycles perfect proximally (fig. $11 \mathrm{H}$ ), including two pairs of directives each associated to one

FIG. 11. External and internal anatomy and histology of Actinoscyphia saginata Verrill, 1882. A, Oral view of preserved specimen; note cuticle (arrow); B, histological cross section through proximal column and 12 cycles of mesenteries attached to introverted pedal disc; note cuticle (arrow); C, histological longitudinal section through distal column and small marginal mesogleal sphincter musculature; $\mathbf{D}$, detail of distal marginal sphincter musculature showing tendency for reticulation distally; E, detail of proximal marginal sphincter musculature and alveolar structure; F, longitudinal section through tentacle showing ectodermal longitudinal musculature (arrow); G, histological section through distal column and mesogleal basal aboral thickening of tentacle (arrow); H, histological cross section through proximal column and cycles of mesenteries; I, detail of pair of sterile mesenteries of fourth cycle with filaments; J, detail of pair of sterile mesenteries of fifth cycle; $\mathbf{K}$, detail of spermatic cysts on mesenteries of third cycle; $\mathbf{L}$, detail of retractor musculature on mesenteries of fourth cycle; $\mathbf{M}$, detail of parietobasilar musculature on a mesentery of second cycle; $\mathbf{N}$, detail of parietobasilar musculature on mesentery of fifth cycle. Abbreviations: fi, filament; $\mathbf{p b}$, parietobasilar musculature; re, retractor musculature; sc, spermatic cysts; sp, marginal sphincter musculature; $\mathbf{t}$, tentacle. Scale bar: A, $40 \mathrm{~mm}$; B, C, G, $0.5 \mathrm{~mm}$; D, E, J, L, $0.1 \mathrm{~mm} ; \mathbf{F}, \mathbf{K}, \mathbf{M}, 0.2 \mathrm{~mm}$ H, $1 \mathrm{~mm} ; \mathbf{I}, 0.25 \mathrm{~mm} ; \mathbf{~ N}, 0.05 \mathrm{~mm}$. 


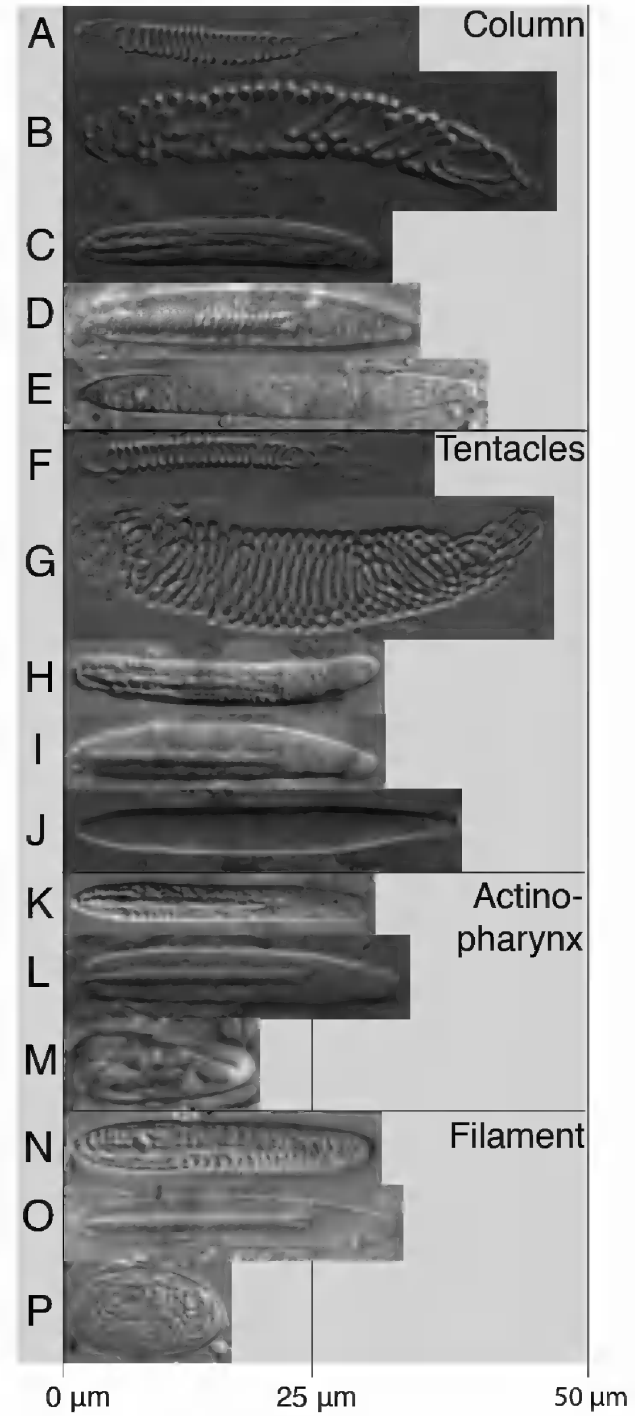

FIG. 12. Cnidom of Actinoscyphia saginata Verrill, 1882: A, B, F, G, spirocyst; C, H, K, N, basitrich; D, I, L, O, p-mastigophore B1; E, J, holotrich; $\mathbf{M}$, immature nematocyst; $\boldsymbol{P}$, medusozoan nematocyst.

siphonoglyph. First cycle sterile; second to third cycles imperfect, fertile, with filaments only proximally (fig. $11 \mathrm{H}$ ); fourth cycle imperfect, sterile, with filaments (fig. 11I); fifth cycle imperfect, sterile, without filaments (fig. 11J). Same number of mesenteries distally and proximally. Mesenteries thin, with some sections with mesogleal thickenings (fig. 11B, H); retractors diffuse slightly more developed distally (fig. 11I, L); well-developed parietobasilar musculature in all mesenteries (fig. 11M) less developed in mesenteries of fifth cycle (fig. 11N). All specimens collected in June and July males; major axis of spermatic cysts $76-238 \mu \mathrm{m}$ (fig. 11K). Species inferred gonochoric.

Cnidom (fig. 12): Spirocysts, basitrichs, p-mastigophores B1, and holotrichs. Some nematocysts found in the actinopharynx (fig. $12 \mathrm{M}$ ) and filament (fig. 12P) are likely the result of contamination by feeding. See figure 12 and table 5 for size and distribution.

Distribution AND NATURAL HISTORY: Actinoscyphia saginata was originally described from the Atlantic coast of the United States off New England (968 m) (Verrill, 1882). The species is also known from the Atlantic coast of France (2108-2177 m) and Morocco (1341-1394 m) (Riemann-Zürneck, 1978). Our specimens extend the geographic distribution of $A$. saginata to the South Atlantic off the coast of Espírito Santo, Brazil and falls within the known bathymetry for the species (1402-1694 m).

Remarks: The genus Actinoscyphia contains five valid species that are easily recognized by their venus flytraplike morphology: large bilobed oral discs and marginal tentacles arranged in two cycles forming a concave surface. The morphology of the body and oral disc enables these anemones to position themselves within the current and and feed on particles upstream. Although the term "venus flytrap anemone" was originally used to refer to species in genus Actinoscyphia, some hormathiids in genera Phelliactis Simon, 1892, and Paraphelliactis Carlgren, 1928b, as well as members of Amphianthus Hertwig, 1882, also have bilobed oral discs with marginal tentacles resembling to the ones seen in actinoscyphiids. The similarity in the venus flytraplike morphology in all these genera has led to misidentification of the many images of venus flytrap anemones attributed to Actinoscyphia, when in fact they refer to other families and genera. In any case, species of Actinoscyphia are mainly distributed in the North Atlantic ( $A$. 


\section{TABLE 5}

\section{Size ranges of the cnidae of Actinoscyphia saginata Verrill, 1882}

Abbreviations and symbols: SD, standard deviation; $N$, Total number of capsules measured; $\mathrm{S}$, proportion of specimens in which each cnidae was found; $\mathrm{F}$, frequency; +++, very common; ++ , common; +, rather common; -, rare.

\begin{tabular}{|c|c|c|c|c|c|}
\hline Categories & $\begin{array}{l}\text { Range of length and width } \\
\text { of capsules }(\mu \mathrm{m})\end{array}$ & Mean \pm SD & $N$ & $S$ & $\mathbf{F}$ \\
\hline \multicolumn{6}{|l|}{ Column } \\
\hline Gracile spirocysts (A) & $26.1-63.5 \times 3.2-7.8$ & $42.5 \pm 8.1 \times 5.1 \pm 1.2$ & 86 & $4 / 4$ & +++ \\
\hline Robust spirocysts (B) & $41.4-79.8 \times 5.2-12.7$ & $59.6 \pm 7.7 \times 8.5 \pm 1.7$ & 73 & $4 / 4$ & +++ \\
\hline Basitrichs (C) & $22.7-32.9 \times 3.8-5.4$ & $28.9 \pm 2.7 \times 4.3 \pm 0.3$ & 66 & $4 / 4$ & ++ \\
\hline$P$-mastigophores A (D) & $25.3-40.4 \times 4.0-6.1$ & $32.2 \pm 4.2 \times 5.0 \pm 0.6$ & 49 & $2 / 4$ & + \\
\hline Holotrichs (E) & $38.1-47.5 \times 4.6-6.0$ & $41.4 \pm 3.3 \times 5.2 \pm 0.5$ & 12 & $1 / 4$ & - \\
\hline \multicolumn{6}{|l|}{ Tentacles } \\
\hline Gracile spirocysts (F) & $24.8-52.6 \times 2.8-7.0$ & $41.9 \pm 6.0 \times 5.1 \pm 0.9$ & 114 & $4 / 4$ & +++ \\
\hline Robust spirocysts (G) & $39.8-85.0 \times 6.0-16.6$ & $56.3 \pm 8.8 \times 8.3 \pm 1.7$ & 210 & $4 / 4$ & +++ \\
\hline Basitrichs $(\mathrm{H})$ & $24.4-66.3 \times 3.4-6.1$ & $31.3 \pm 3.0 \times 4.4 \pm 0.4$ & 197 & $4 / 4$ & +++ \\
\hline$P$-mastigophores A (I) & $24.8-48.9 \times 3.8-6.9$ & $39.3 \pm 4.5 \times 5.0 \pm 0.6$ & 117 & $4 / 4$ & +++ \\
\hline Holotrichs (J) & $34.2-50.1 \times 3.8-5.5$ & $40.3 \pm 3.0 \times 4.5 \pm 0.3$ & 56 & $2 / 4$ & ++ \\
\hline \multicolumn{6}{|l|}{ ACTINOPHARYNX } \\
\hline Basitrichs (K) & $28.1-37.7 \times 3.7-5.6$ & $32.5 \pm 2.9 \times 4.6 \pm 0.5$ & 104 & $4 / 4$ & +++ \\
\hline$P$-mastigophores A (L) & $25.8-33.9 \times 3.4-7.5$ & $29.2 \pm 1.8 \times 5.5 \pm 1.1$ & 94 & $4 / 4$ & +++ \\
\hline Holotrichs (M) & $14.1-15.6 \times 5.0-6.1$ & $14.9 \pm 0.6 \times 5.5 \pm 0.4$ & 4 & $1 / 4$ & - \\
\hline \multicolumn{6}{|l|}{ Filament } \\
\hline Basitrichs I (N) & $22.3-37.0 \times 3.8-5.2$ & $31.1 \pm 2.8 \times 4.4 \pm 0.3$ & 101 & $4 / 4$ & +++ \\
\hline$P$-mastigophores A (O) & $23.3-31.4 \times 3.7-5.5$ & $26.4 \pm 1.9 \times 4.4 \pm 0.5$ & 67 & $4 / 4$ & ++ \\
\hline Medusozoan nematocysts (P) & $32.6-43.8 \times 4.8-6.0$ & $38.9 \pm 3.7 \times 5.4 \pm 0.4$ & 7 & $1 / 4$ & - \\
\hline
\end{tabular}

saginata, A. aurelia) or northeastern Pacific ( $A$. groendyki) with only one species known from the sub-Antarctic region of the Pacific and Atlantic region of Antarctica (A. plebeia: Rodríguez and López-González, 2013) as well as off the South African coast (Laird and Griffiths, 2016). Though A. groendyki was originally described based on material collected in the northeastern Pacific and specimens of A. plebeia from the Southern Ocean examined by Fautin (1984), we agree with Rodríguez and LópezGonzález (2013) and restrict the distribution of A. groendyki to the northeastern Pacific and of A. plebeia to the Southern Ocean.
Actinoscyphia species are differentiated based on their external anatomy (size and number of tentacles and its mesogleal basal aboral thickenings; pedal disc shape and size; oral disc shape and coloration), internal anatomy (number of perfect pairs of mesenteries; number of cycles of mesenteries, fertility), microanatomy (thickness of mesoglea; development and morphology of marginal sphincter musculature; pigmentation of alveoli in sphincter musculature) and cnidae (presence of holotrichs in tentacles, $p$-mastigophores B1 in column and tentacles, etc.). For a dichotomous key of Actinoscyphia species see Eash- 
Loucks and Fautin (2012). The Brazilian specimens of $A$. saginata agree well with previous descriptions of the species (e.g., Stephenson, 1918b; Riemann-Zürneck, 1978) and can be identified unequivocally by a combination of characters related to its shape (large, shapeless body), pedal disc (tubular shaped and attached to solid substrates), oral disc (irregular but not bilobed), tentacles (relatively long with mesogleal basal aboral thickenings), coloration (dark-brown tentacles, oral disc, and pharynx), sphincter musculature (nonpigmented alveoli), and cnidae ( $p$-mastigophores B1 in column). The cnidae of the Brazilian specimens of $A$. saginata closely agrees with the cnidom provided by Riemann-Zürneck (1978) for the species, with a few minor differences: we found in our specimens many spirocysts as well as few holotrichs in the column, no small basitrichs in the tentacles, and longer basitrichs in filaments. These differences, however, do not prevent the identification of Brazilian specimens as $A$. saginata.

\section{Family Amphianthidae Hertwig, 1882}

\section{Genus Amphianthus Hertwig, 1882}

Diagnosis (modified from Carlgren, 1949; modifications in bold): Amphianthidae with broad pedal disc, often elongated in transversal or sagittal plane. Column smooth or with small mesogleal papillae in longitudinal rows distally. Cinclides as a rule only on directive endoceles, few in number (1-3 or a few more?); external opening often on papillae; cinclides sometimes indistinct or absent. Mesogleal marginal sphincter musculature strong. Tentacles robust, always fewer than mesenteries at limbus, sometimes with mesogleal basal aboral thickenings. Longitudinal muscles of tentacles and radial musculature of oral disc ectodermal. One to three siphonoglyphs. Pairs of perfect mesenteries at least six, often irregular. One to three pairs of directives. Stronger mesenteries fertile except sometimes the directives. Retractors diffuse, usually fairly weak. Acon- tia well developed. Cnidom: spirocysts, basitrichs, p-mastigophores B1, and holotrichs.

TyPe sPeCIEs: Amphianthus bathybium Hertwig, 1882, by original designation.

VAlid SPECIES: Amphianthus armatus Carlgren, 1928a; A. bathybium; A. brunneus (Pax, 1909); A. californicus Carlgren, 1936; A. capensis Carlgren, 1928a; A. caribaeus (Verrill, 1899); A. dohrnii (Koch, 1878); A. ingolfi Carlgren, 1942; A. islandicus Carlgren, 1942; A. lacteus (McMurrich, 1893); A. laevis Carlgren, 1938; A. margaritaceus (Danielssen, 1890); A. michaelsarsi Carlgren, 1934; A. minutus (Hertwig, 1882); A. mirabilis (Verrill, 1879); A. mopseae (Danielssen, 1890); A. natalensis Carlgren, 1938; A. nitidus (Verrill, 1899); A. norvegicus Carlgren, 1942; A. radiatus Carlgren, 1928a; A. rosaceus Wassilieff, 1908; A. sanctaehelenae Carlgren, 1941a; A. valdiviae Carlgren, 1928a; A. verruculatus Carlgren, 1942 (Fautin, 2016).

\section{Amphianthus lacteus (McMurrich, 1893)}

Figures 13-14, table 6

MATERIAL: MNRJ 8273 (4 specimens); locality: Projeto PIR 2, Sta. Fasciologia Norte PIR-2, Amostrador Box core Zona 235, southwestern Atlantic, Brazil, off the coast of São Paulo, $24^{\circ} 49.45^{\prime} \mathrm{S}, 44^{\circ} 23.02^{\prime} \mathrm{W}$, collected on 16 December 2008 by R/V F. Odyssey (no depth data). MNRJ 8284 (4 specimens); locality: Projeto PIR 2, Sta. Fasciologia Sul PIR-2, Amostrador Box core Zona 235, southwestern Atlantic, Brazil, off the coast of São Paulo, $24^{\circ} 55.37^{\prime}$ S $44^{\circ} 27.23^{\prime}$ W, collected on 10 December 2008 by R/V F. Odyssey $(735 \mathrm{~m})$.

Material eXAmined: Amphianthus michaelsarsi: MZB 39191 (8 specimens, syntypes); locality: Michael Sars Expedition 1910, St. 53, North Atlantic Ocean, $34^{\circ} 59.0^{\prime} \mathrm{N} 33^{\circ} 01.0^{\prime} \mathrm{W}$, collected 8 June 1920 by O. Carlgren (2615 m).

External anatomy (fig. 13): Pedal disc flat, irregularly shaped, highly adherent, broader than column diameter, $16-21 \mathrm{~mm}$ in diameter in preserved specimens (fig. 13A). Column cylindrical, smooth not visibly divisible into regions (fig. 


\section{TABLE 6}

Size ranges of the cnidae of Amphianthus lacteus (McMurrich, 1893)

Abbreviations and symbols: SD, standard deviation; $N$, Total number of capsules measured; $S$, proportion of specimens in which each cnidae was found; F, frequency; +++, very common; ++ , common; +, rather common; -, rare.

\begin{tabular}{|c|c|c|c|c|c|}
\hline Categories & $\begin{array}{l}\text { Range of length and width of } \\
\text { capsules }(\mu \mathrm{m})\end{array}$ & Mean \pm SD & $N$ & $S$ & $\mathbf{F}$ \\
\hline \multicolumn{6}{|l|}{ Column } \\
\hline Basitrichs (A-B) & $11.4-30.2 \times 2.0-3.7$ & $17.8 \pm 5.0 \times 2.6 \pm 0.3$ & 141 & $4 / 4$ & +++ \\
\hline$P$-mastigophores B1 (C) & $25.1-27.2 \times 3.7-3.8$ & $26.2 \pm 1.5 \times 3.8 \pm 0.1$ & 4 & $1 / 4$ & - \\
\hline \multicolumn{6}{|l|}{ Tentacles } \\
\hline Gracile spirocysts (D) & $22.7-54.9 \times 2.9-8.3$ & $35.4 \pm 7.4 \times 4.7 \pm 1.3$ & 85 & $4 / 4$ & +++ \\
\hline Robust spirocysts (E) & $27.1-57.5 \times 4.9-8.7$ & $42.8 \pm 6.2 \times 6.4 \pm 0.8$ & 70 & $4 / 4$ & +++ \\
\hline$P$-mastigophores B1 (F) & $15.7-21.7 \times 3.2-5.3$ & $18.8 \pm 1.7 \times 4.6 \pm 0.4$ & 36 & $4 / 4$ & +++ \\
\hline$P$-mastigophores B2 (G) & $23.7-30.7 \times 3.9-5.9$ & $26.7 \pm 1.7 \times 5.0 \pm 0.5$ & 56 & $4 / 4$ & +++ \\
\hline Holotrichs I (H) & $23.0-33.4 \times 3.6-4.4$ & $29.6 \pm 3.4 \times 4.0 \pm 0.3$ & 40 & $4 / 4$ & + \\
\hline Holotrich II (I-J) & $29.6-47.0 \times 4.2-6.9$ & $39.5 \pm 3.0 \times 5.4 \pm 0.5$ & 102 & $4 / 4$ & +++ \\
\hline \multicolumn{6}{|l|}{ ACTINOPHARYNX } \\
\hline Basitrichs (K) & $22.3-34.5 \times 2.6-4.0$ & $28.0 \pm 2.1 \times 3.2 \pm 0.3$ & 79 & $4 / 4$ & ++ \\
\hline$P$-mastigophores $\mathrm{B} 1(\mathrm{~L}-\mathrm{M})$ & $17.1-36.3 \times 2.9-6$ & $23.8 \pm 3.2 \times 4.1 \pm 0.5$ & 168 & $4 / 4$ & +++ \\
\hline \multicolumn{6}{|l|}{ FILAMENT } \\
\hline Basitrichs I (N) & $7.5-19.0 \times 2.0-3.1$ & $9.7 \pm 1.8 \times 2.4 \pm 0.3$ & 71 & $4 / 4$ & + \\
\hline Basitrichs II (O) & $44.5-58.2 \times 4.2-5.3$ & $52.2 \pm 3.8 \times 4.8 \pm 0.4$ & 33 & $2 / 4$ & - \\
\hline$P$-mastigophores $\mathrm{B} 1(\mathrm{P}-\mathrm{Q})$ & $19.1-29.0 \times 2.6-5.0$ & $25.0 \pm 1.8 \times 3.8 \pm 0.4$ & 138 & $4 / 4$ & +++ \\
\hline \multicolumn{6}{|l|}{ ACONTIA } \\
\hline Basitrichs I (R) & $12.6-25.8 \times 2.0-4.6$ & $16.8 \pm 3.7 \times 2.9 \pm 0.8$ & 53 & $4 / 4$ & + \\
\hline Basitrichs II (S) & $42.2-57.8 \times 3.8-6.2$ & $51.8 \pm 2.6 \times 4.8 \pm 0.5$ & 252 & $4 / 4$ & +++ \\
\hline
\end{tabular}

13A); cinclides absent. Column white in preservation with beige, thin, deciduous cuticle (fig. 13A). Column $12-21 \mathrm{~mm}$ in diameter and $12-15 \mathrm{~mm}$ in length. Small fosse. Oral disc circular, as wide or slightly wider than column with central, with large mouth (fig. 13B). Oral disc diameter 10-11 mm in preserved specimens. Tentacles 90-94, smooth, short, beige same color as column, with no markings, in 5 cycles $(6+4+10+20+n)$ in outer half of oral disc in preserved specimens (fig. 13B); inner longer than outer ones with longest tentacle up to $25 \mathrm{~mm}$ in preserved specimens.

INTERNAL ANATOMY AND HISTOLOGY (fig. 13): Body-wall thickness varying along column: all three body layers thicker in scapulus than scapus (fig. 13C). Sphincter long, narrow, with mesogleal musculature (fig. 13C); fibers in most of mesoglea distally, thinner proximally (fig. 13C). Longitudinal musculature of tentacles ectodermal (fig. 13D); no mesogleal basal aboral thickening on tentacles. Longitudinal musculature of oral disc ectodermal (fig. $13 \mathrm{E})$. Actinopharynx very short, longitudinally sulcated throughout (fig. 13F, G). Specimens with two weakly differentiated siphonoglyphs (fig. 13G).

Mesenteries decamerous, in four cycles $(6+4+10+20=40$ pairs $)$ : first and second cycles perfect, including one pair of directives associated to one siphonoglyph (fig. 13F, G); third and 

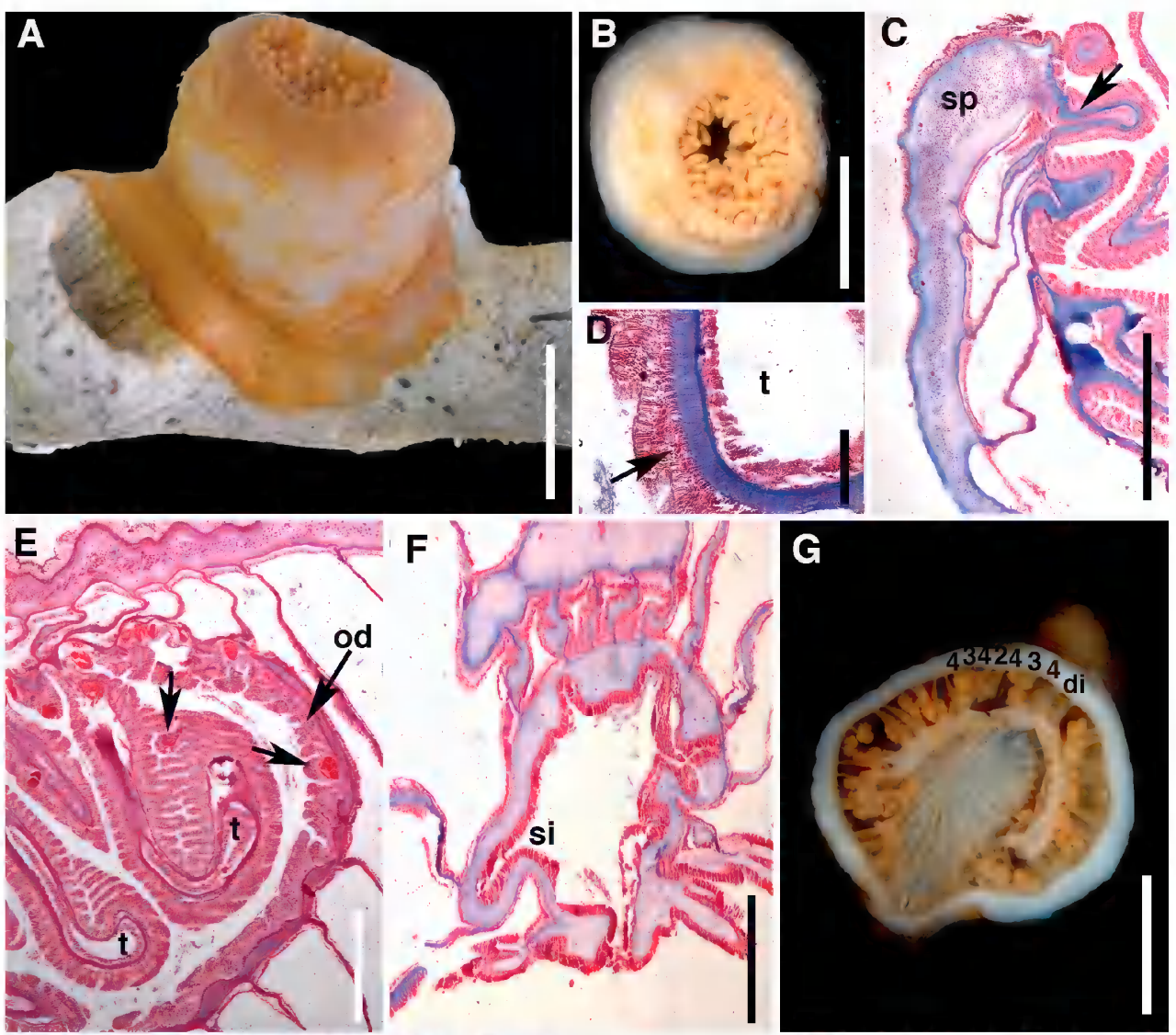

G
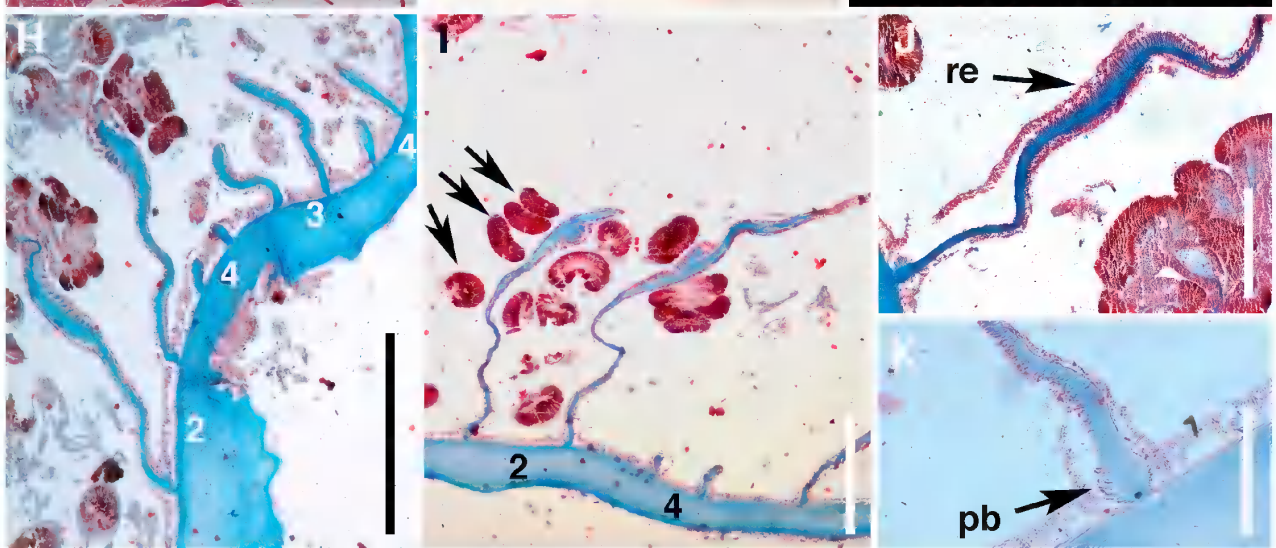

FIG. 13. External and internal anatomy and histology of Amphianthus lacteus (McMurrich, 1893). A, Lateral view of preserved specimen attached to scleractinian coral; B, oral view of preserved specimen showing tentacles; C, longitudinal section through distal column and long and narrow mesogleal sphincter musculature; note absence mesogleal basal aboral thickening of tentacle (indicated by arrow); $\mathbf{D}$, cross section through tentacle and ectodermal longitudinal musculature (indicated by arrow); E, cross section through oral disc showing larvae (arrows) on oral disc and tentacles; F, cross section at actinopharynx level and single siphonoglyph; G, cross section through column at actinopharynx level and cycles of mesenteries (numbers); $\mathbf{H}$, cross section through proximal column and pairs of mesenteries of second, third, and fourth cycles; I, cross 
fourth cycles imperfect (fig. 13G). All mesenteries of first to third cycles, including directives, with filaments and acontia (fig. 13G); those of fourth cycle without filaments or acontia (fig. 13G-I). Mesenteries more numerous proximally. Retractors of first and second cycles weakly developed, diffuse, restricted to distal half of mesentery (figs. $13 \mathrm{H}, \mathrm{J}$ ); those of third and fourth cycles weakly diffuse (fig. 13H). Acontia very abundant on mesenteries of first and second cycles (fig. 13H, I). Parietobasilar musculature small, weak in all mesenteries, including stronger ones (fig. 13K). Basilar musculature of mesenteries weak (not shown). Gametogenic tissue on all mesenteries except in directives and those of forth cycle (fig. 13G). Eggs/larvae in oral disc and tentacles (fig. 13E).

CNidom (fig. 14): Spirocysts, basitrichs, $b$-mastigophores, $p$-mastigophores $\mathrm{B} 1, p$-mastigophores B1, and holotrichs. Some $p$-mastigophores B1 are likely immature capsules (fig. 14F, L, P). See figure 14 and table 6 for size and distribution.

Distribution AND NATURAL History: Specimens were collected attached to skeletons of the scleractinian Solenosmilia variabilis Duncan, 1873 (fig. 13A) in the Santos Basin off the coast of São Paulo, Brazil at $735 \mathrm{~m}$. Amphianthus lacteus is known from its type locality on the eastern Pacific (Chile) and from specimens identified as $A$. aff. lacteus reported from several localities off the coast of Argentina from around Burdwood Bank to Rio de La Plata (Riemann-Zürneck, 1986). The Brazilian specimens examined here extend the geographic range of $A$. lacteus further north across the Rio de La Plata and fall into the known bathymetric range of the species (398-821 m).

REMARKs. The presence of acontia with only basitrichs and the 12 perfect pairs of mesenteries unequivocally place our specimens within Amphianthidae (Rodríguez et al., 2012). In addition, our specimens also exhibit a modified, grasping pedal disc, which is diagnostic for the group Graspina sensu Rodríguez et al. (2012) (i.e., Amphianthidae plus Actinoscyphiidae Stephenson, 1920). The morphological distinction between Amphianthus and Stephanauge Verrill, 1899, is difficult, but the abundance of acontia in our specimens (fig. 13I) identifies them as Amphianthus rather than Stephanauge, because Stephanauge species have few to no acontia (Carlgren, 1949). Even harder is make definitive identifications of the 24 valid species of Amphianthus (Fautin, 2016), which led Riemann-Zürneck (1986) to suggest that identification of the species of Amphianthus from Argentina required a revision of the entire genus. We agree with Riemann-Zürneck (1986) in that specific identification within Amphianthus is rather difficult, but using the combination of the wide, circular pedal disc of the Brazilian specimens, which is not elongated in the sagittal plane as in many other Amphianthus, the decamerism of our specimens (rare within the genus), the lack of tubercles on the distal column and conspicuous cinclides, we can identify our specimens as A. lacteus. Our specimens agree in all morphological details with those described by McMurrich (1893). We provide the cnidae of the species for the first time, which was not given by McMurrich (1893). We found several eggs/larvae in the oral disc and tentacles of our specimens (fig. 13E), a feature also found in other species with similar wide distribution in the SWA (e.g., Paractis laevis (Carlgren, 1899), Antholoba achates (Drayton in Dana, 1846).

section through a pair of second cycle and thick mesoglea; note abundant acontia (arrows); J, detail of retractor musculature on a mesentery of first cycle; $\mathbf{K}$, cross section through a mesentery of second cycle with weak parietobasilar musculature. Abbreviations: di, directive mesenteries; od, oral disc; pb, parietobasilar musculature; re, retractor musculature; si, siphonoglyph; sp, marginal sphincter musculature; $\mathbf{t}$, tentacle. Scale bars: A, B, G, $6 \mathrm{~mm}$; C, $0.4 \mathrm{~mm}$; D, K, $0.1 \mathrm{~mm}$; E, F, H, I, $0.6 \mathrm{~mm}$; J, $0.2 \mathrm{~mm}$. 


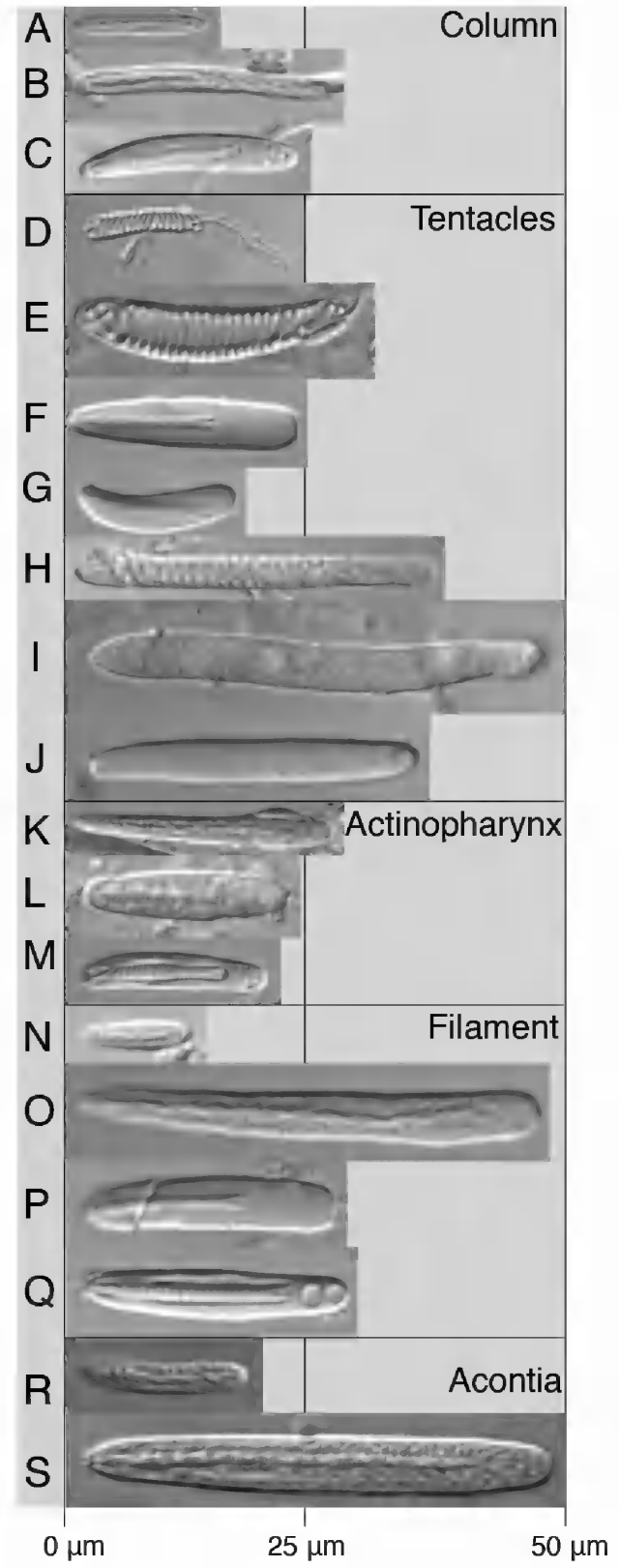

FIG. 14. Cnidom of Amphianthus lacteus (McMurrich, 1893): A, B, K, N, R, S, basitrich; C, F, L, Q, p-mastigophore B1; D, E, spirocyst; G, M, P, immature p-mastigophore $\mathrm{B} 1 ; \mathbf{H}$-J, holotrich, $\mathbf{O}$, $b$-mastigophore.
Family Hormathiidae Carlgren, 1932

Genus Chondrophellia Carlgren, 1925

DiAgnosis (modified from Zelnio et al., 2009; modifications in bold): Hormathiidae with welldeveloped pedal disc. Body elongated, without cinclides, divisible into scapus and scapulus; scapus with cuticle and tubercles distally, 12 or 24 short rows of conspicuous tubercles. Scapulus longitudinally sulcated. Very strong mesogleal marginal sphincter. Tentacles hexamerously arranged. Longitudinal muscles of tentacles and radial muscles of oral disc ectodermal. Six pairs of perfect mesenteries. Mesenteries of oldest cycles, including directives, fertile, with filaments and acontia. Mesenteries of youngest full cycle and of any subsequent partial cycles present only proximally, sterile, without filaments or acontia. Same number or fewer mesenteries at midcolumn than distally or proximally. Below actinopharynx, inner part of nondirective mesenteries may curve toward exoceles. Perfect and stronger imperfect mesenteries with diffuse retractors; retractors usually fairly close to body wall. Parietobasilar muscles weak. Acontia well developed. Cnidom: Spirocysts, basitrichs, $\boldsymbol{p}$-mastigophores $\mathbf{A}$, and $\boldsymbol{p}$-mastigophores $\mathbf{B} \mathbf{1}$.

Type sPecies: Actinauge nodosa var. coronata Verrill, 1883, by original designation.

VALID SPECIES: Chondrophellia africana Carlgren, 1928a; C. coronata; and C. orangina Zelnio et al., 2009.

\section{Chondrophellia coronata (Verrill, 1883)}

Figures 15-16, table 7

MATERIAL: MNRJ 5714 (1 specimen); locality: OceanProf II-BC Norte-Cenpes/UFRJ, dredging \#16-1, N/RB Astro Garoupa, southwestern Atlantic, Brazil, off the coast of Rio de Janeiro (RJ), $23^{\circ} 27.73^{\prime} \mathrm{S}-22^{\circ} 15.07^{\prime} \mathrm{S} 39^{\circ} 59.0^{\prime}$ W-39 $55.72^{\prime} \mathrm{W}$, collected on 22 August 2003 by ? (1059-1110 m). MNRJ 5687 (3 specimens); locality: Projeto OceanProf II-BC Sul-Cenpes/ UFRJ, N/RB Astro Garoupa, southwestern 
Atlantic, Brazil, off the coast of Rio de Janeiro (RJ), $22^{\circ} 28.65^{\prime} \mathrm{S} \quad 40^{\circ} 04.30^{\prime} \mathrm{W} / 22^{\circ} 29.7^{\prime} \mathrm{S}$ $40^{\circ} 05.1^{\prime} \mathrm{W}$, collected on 25 August 2003 (12901325 m). MNRJ 6918 (1 specimens); locality: southwestern Atlantic, Brazil, off the coast of Rio de Janeiro (RJ), Projeto OceanProf I-BC Norte-Cenpes/UFRJ, dredging \#15, N/RB Astro Garoupa, $22^{\circ} 01.98^{\prime}$ S $-21^{\circ} 52.22^{\prime}$ S $39^{\circ} 49.87^{\prime}$ W-40 $02.28^{\prime} \mathrm{W}$, collected on 14 February 2003 (1620-1598 m). MNRJ 6664 (2 specimens); locality: Projeto Caracterização de corais de água profunda, Mergulho 2, Área 32, Banco 85N, Dop. 8, ROV Toisa Conqueror, southwestern Atlantic, Brazil, off the coast of Rio de Janeiro (RJ), $22^{\circ} 25.73^{\prime} \mathrm{S} 39^{\circ} 57.73^{\prime} \mathrm{W}$, collected on 23 July 2005 (1059-1110 m).

External AnAtomy (fig. 15): Pedal disc flat, circular, highly adherent, equal to or broader than column, insertion of mesenteries visible when exposed, 3-13 $\mathrm{mm}$ in diameter in preserved specimens (fig. 15B). Column cylindrical, mostly covered by small tubercles (fig. 15A) in proximal and midcolumn, with a distal crown of 12 larger tubercles above which 12 smaller tubercles are (fig. 15B, C); column divided into long scapus and short scapulus with longitudinal ridges (fig. 15C). Column with thick, deciduous cuticle, highly adherent in some preserved specimens (fig. 15A) or entirely missing in others (fig. $15 \mathrm{~A}-\mathrm{C}$ ). Margin of scapulus not tentaculate (fig. 15C). Cinclides absent. Column white in preserved specimens with mesenterial insertions visible as white lines, particularly in proximal column and limbus without cuticle (fig. 15B). Column 9-25 mm in length and 5-18 $\mathrm{mm}$ in diameter in preserved specimens. Oral disc circular, small, as wide or slightly narrower than column, mostly retracted in preserved specimens (fig. 15C). Central, small mouth. Oral disc diameter $1-6 \mathrm{~mm}$ in preserved specimens (fig. 15B, C). Tentacles up to 96 , smooth, short, slender, and pointed, in five cycles $(6+6+12+24+n)$ in preserved specimens. Tentacles with no markings and translucent beige in preserved specimens (fig. 15C). Longest tentacle up to $3 \mathrm{~mm}$ in preserved specimens.
INTERNAL ANATOMY AND HISTOLOGY (fig. 15): Body long and narrow in preserved specimens (fig. 15A, B) with wall thickness varying along column: mesoglea thicker in scapulus than in scapus, whereas epidermis is thicker in scapus than in scapulus (fig. 15D, E). Marginal sphincter long, with mesogleal musculature (fig. 15E); fibers in most of mesoglea distally (fig. 15E); alveolar proximally with tendency for reticulation elsewhere (fig. 15F). Longitudinal musculature of tentacles ectodermal (fig. 15G). Actinopharynx up to $8 \mathrm{~mm}$ in length, approximately one third of column's length; longitudinally sulcated throughout (fig. 15H, I); with thick mesoglea (fig. 15J, I). Specimens with two weakly differentiated siphonoglyphs (fig. 15H, I) with thin gastrodermis and mesoglea, but glandular epidermis as in actinopharynx.

Mesenteries hexamerously arranged in four cycles $(6+6+12+24=48)$ : first cycle perfect, including two pairs of directives, each associated to one siphonoglyph (fig. 15I); second and third cycles imperfect (fig. 15I). All mesenteries of first and second cycles, including directives, fertile and with filaments (fig. 15J-L, N); those of third cycle sterile and without filaments (fig. 15M). A fourth cycle of imperfect, sterile mesenteries only proximally; insertion of mesenteries visible on limbus (fig. 15B). More mesenteries proximally than distally (fig. 15B). All fertile specimens female, collected in July; major axis of oocytes up to $72 \mu \mathrm{m}$ in diameter (fig. $15 \mathrm{~N}$ ). Species inferred gonochoric. Retractors of first and second cycles well developed, diffuse (fig. 15J-L); those of third cycle diffuse (fig. 15J, M). Parietobasilar musculature small, weak in all mesenteries (fig. 15K-M). Basilar musculature of mesenteries weak (not shown).

CNidom (fig. 16): Spirocysts, basitrichs, p-mastigophores $\mathrm{A}$, and p-mastigophores $\mathrm{B} 1$. The scyphozoanlike nematocyst (fig. 16L) found in the filament of this species is likely the result of contamination by feeding. See figure 16 and table 7 for size and distribution.

Distribution AND NATURAL HISTORY: Specimens of Chondrophellia coronata were 

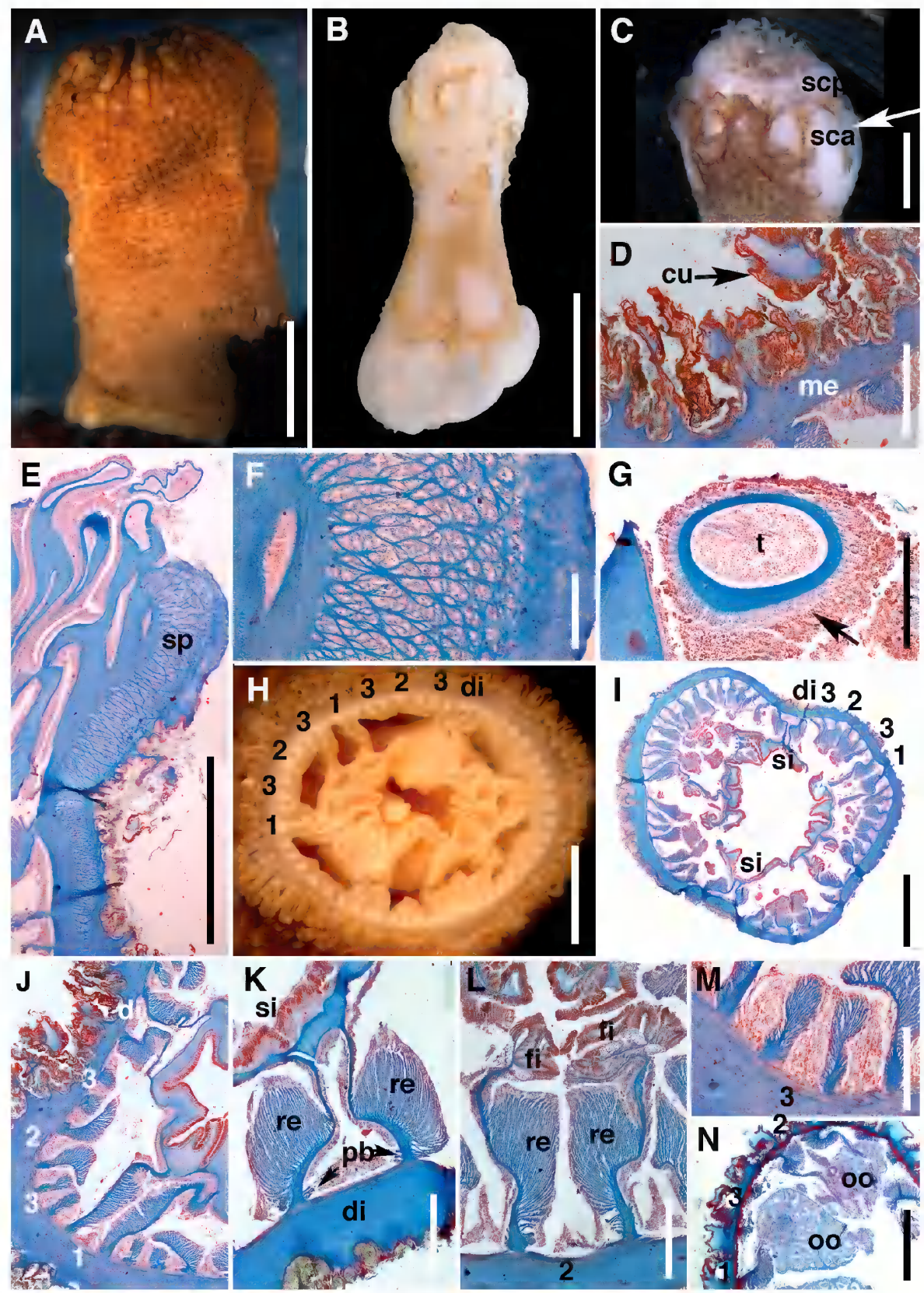

FIG. 15. External and internal anatomy and histology of Chondrophellia coronata (Verrill, 1883). A, Lateral view of preserved specimen showing column with cuticle; note smaller tubercles on scapus and larger ones forming a crown around distal scapus; B, lateral view of preserved specimen, column without epidermis and cuticle; note insertion of mesenteries on limbus; $\mathbf{C}$, detail of scapus with thick cuticle and short scapulus; note crown of larger tubercles and one ring of smaller tubercles just above it (arrows); D, cross section through midcolumn and thick mesoglea, corrugated thin epidermis, and thick cuticle; E, longitudinal section through distal scapus and long mesogleal sphincter musculature; F, detail of mesogleal sphincter and reticular arrangement of fibers; G, cross section through tentacle with weak ectodermal longitudinal musculature (arrow); $\mathbf{H}$, cross section through scapus at actinopharynx level with 24 pairs of mesenteries in three cycles (numbers); 
collected off the coast of Rio de Janeiro state close to the Campos Basin in Brazil. Some of these specimens were collected attached to pieces of coral skeleton. Chondrophellia coronata is widely distributed in the North Atlantic (Carlgren, 1942; Molodtsova et al., 2008) and Gulf of Mexico (Ammons and Daly, 2008), but this is the first record of the species in the South Atlantic. The species has also been collected in the eastern Pacific off the coast of Chile (McMurrich, 1893) and off California (Doumenc and Van Präet, 1988). The Pacific records for C. coronata are somewhat questionable (Carlgren, 1942; Molodtsova et al., 2008; Zelnio et al., 2009). The specimens of $C$. coronata examined by Doumenc and Van Präet (1988) were collected in hydrothermal vents of the eastern Pacific and are similar to C. orangina collected off hydrothermal vents in the Lau Basin in the southwestern Pacific (Zelnio et al., 2009). The specimens of $C$. coronata off Brasil were collected between 1077-1620 m, which falls within the known range for the North Atlantic records (599-2448 m).

REMARKs: The Brazilian specimens of Chondrophellia coronata agree closely with previous morphological descriptions of external and internal anatomy for the species (Carlgren, 1942). In particular, the distinctive combination of a distal corona of tubercles, the number of cycles of mesenteries (three spanning most of the column and a fourth only proximally), and the fertility of first and second cycles of mesenteries easily places our material within Chondrophellia. Types and size range of nematocysts from our specimens agree with those given by
Carlgren (1942) and Zelnio et al. (2009) for C. coronata, except for the small basitrichs in the column and acontia found only in our specimens. These differences could be explained by the scarcity and difficulty of finding these small nematocysts, particularly in the acontia where the larger category is abundant. Our specimens are different from the $C$. coronata identified by Ammons and Daly (2008) in the Gulf of Mexico, which, given the asymmetrical morphology of the oral disc, resemble species of Phelliactis or Paraphelliactis.

The cnidae of Chondrophellia coronata from Brazil differs from the cnidae of C. africana Carlgren, 1928b, given by Zelnio et al. (2009). Our specimens are clearly different from $C$. orangina, based on the number of mesenteries (four cycles in C. coronata; five in C. orangina) and tentacles (five cycles in $C$. coronata; six in C. orangina), number of distal tubercles (12 rows in C. coronata; 24 in $C$. orangina), sphincter musculature (mostly reticular in C. coronata; alveolar in C. orangina), and other cnidae differences. Given the larger size of Chondrophellia specimens collected in the Pacific, it is possible that the Chilean specimens described by McMurrich (1893) and later examined by Carlgren (1942) as well as the C. coronata described by Doumenc and Van Präet (1988) for the eastern Pacific are similar to C. orangina from the Lau Basin in the western Pacific. A detailed revision of the mesentery arrangement of the material from Chile and California could help elucidate the specific identity of eastern Pacific Chondrophellia.

note six pairs of perfect mesenteries of first cycle; I, cross section through scapus at actinopharynx level and cycles of mesenteries (indicated by numbers); J, cross section through column at the actinopharynx level and three cycles of mesenteries (indicated by numbers); $\mathbf{K}$, detail of a pair of directive mesenteries attached to actinopharynx not differentiated into a siphonoglyph; note the weak, diffuse retractor and short, weak parietobasilar musculature; $\mathbf{L}$, detail of a pair of mesentery of second cycle with weak, diffuse retractor musculature and weak parietobasilar; $\mathbf{M}$, detail of a pair of mesenteries of third cycle with weak diffuse retractor and weak parietobasilar musculatures; $\mathbf{N}$, one mesentery of first cycle and one pair of second cycle fertile. Abbreviation: cu, cuticle; di, directive pair of mesenteries; fi, filaments; me, mesoglea; oo, oocytes; pb, parietobasilar musculature; scp, scapulus; sca, scapus; si, siphonoglyph; sp, marginal sphincter musculature. Scale bars: A, $5 \mathrm{~mm}$; B, $8 \mathrm{~mm}$; C, $3 \mathrm{~mm}$; D, E, L-N, $0.4 \mathrm{~mm}$; F, $0.1 \mathrm{~mm} ; \mathrm{G}, \mathbf{K}, 0.2 \mathrm{~mm}$; H, $2 \mathrm{~mm}$; I, J, $1 \mathrm{~mm}$. 


\section{TABLE 7}

Size ranges of the cnidae of Chondrophellia coronata (Verrill, 1883)

Abbreviations and symbols: SD, standard deviation; $N$, Total number of capsules measured; $S$, proportion of specimens in which each cnidae was found; F, frequency; +++, very common; ++, common; +, rather common; -, rare.

\begin{tabular}{|c|c|c|c|c|c|}
\hline Categories & $\begin{array}{l}\text { Range of length and width of } \\
\text { capsules }(\mu \mathrm{m})\end{array}$ & Mean \pm SD & $N$ & $S$ & $\mathbf{F}$ \\
\hline \multicolumn{6}{|l|}{ Column } \\
\hline Basitrich I (A) & $7.4-11.6 \times 1.2-2.4$ & $9.1 \pm 0.8 \times 1.8 \pm 0.2$ & 90 & $3 / 3$ & +++ \\
\hline Basitrich II (B) & $11.6-17.9 \times 2.1-3.0$ & $13.5 \pm 1.4 \times 2.6 \pm 0.2$ & 70 & $2 / 3$ & ++ \\
\hline$P$-mastigophores B1 (C) & $17.6-37.3 \times 2.8-4.8$ & $24.6 \pm 4.2 \times 3.7 \pm 0.5$ & 85 & $3 / 3$ & +++ \\
\hline \multicolumn{6}{|l|}{ Tentacles } \\
\hline Spirocysts (D) & $17.1-66.7 \times 2.8-10.0$ & $33.9 \pm 7.5 \times 5.0 \pm 1.0$ & 164 & $3 / 3$ & +++ \\
\hline Basitrichs I (E) & $10.9-14.9 \times 1.6-2.7$ & $12.9 \pm 1.1 \times 2.1 \pm 0.2$ & 64 & $3 / 3$ & ++ \\
\hline Basitrichs II (F) & $27.8-52.1 \times 2.3-4.0$ & $44.6 \pm 5.1 \times 3.1 \pm 0.3$ & 86 & $3 / 3$ & ++ \\
\hline \multicolumn{6}{|l|}{ ACTINOPHARYNX } \\
\hline Basitrichs I (G) & $11.8-19.4 \times 1.8-2.6$ & $14.7 \pm 1.5 \times 2.2 \pm 0.2$ & 74 & $3 / 3$ & ++ \\
\hline Basitrichs II (H) & $22.9-34.9 \times 2.5-4.0$ & $30.0 \pm 2.6 \times 3.1 \pm 0.3$ & 86 & $3 / 3$ & ++ \\
\hline$P$-mastigophores B1 I (I) & $20.8-35.4 \times 3.5 \pm 5.3$ & $28.0 \pm 2.9 \times 4.1 \pm 0.4$ & 84 & $3 / 3$ & ++ \\
\hline \multicolumn{6}{|l|}{ Filament } \\
\hline Basitrichs I (J) & $10.6-16.2 \times 1.8-2.5$ & $13.6 \pm 1.1 \times 2.2 \pm 0.2$ & 80 & $3 / 3$ & ++ \\
\hline$P$-mastigophores $\mathrm{B} 1 \mathrm{I}(\mathrm{K})$ & $25.6-33.6 \times 2.9-4.7$ & $29.5 \pm 1.9 \times 3.9 \pm 0.4$ & 74 & $3 / 3$ & ++ \\
\hline Holotrichs (L) & $6.7-10.0 \times 4.4-5.7$ & $8.9 \pm 0.7 \times 4.8 \pm 0.2$ & 40 & $3 / 3$ & ++ \\
\hline \multicolumn{6}{|l|}{ ACONTIA } \\
\hline Basitrichs I (M) & $14.0-18.5 \times 1.7-2.4$ & $16.7 \pm 1.6 \times 2.1 \pm 0.2$ & 40 & $3 / 3$ & + \\
\hline Basitrichs II (N) & $38.0-56.6 \times 2.4-4.0$ & $45.3 \pm 3.7 \times 3.2 \pm 0.3$ & 214 & $3 / 3$ & +++ \\
\hline
\end{tabular}

\section{Genus Hormathia Gosse, 1859}

Diagnosis (modified from Carlgren, 1949; modification in bold): Hormathiidae with welldeveloped pedal disc often attached to shells. Column divisible into scapus and scapulus; scapus with tubercles sometimes on longitudinal rows, more rarely in coronal tubercles on distal scapus. Scapus usually with more or less strong cuticle. Marginal sphincter musculature mesogleal, strong. Tentacles not more than 96, exceptionally few more, without mesogleal basal aboral thickenings. Same number of mesenteries proximally and distally. Longitudinal muscles of tentacles and radial muscles of oral disc ectodermal; latter sometimes mesoectodermal. Two well-developed siphonoglyphs. Six pairs of perfect and sterile mesenteries. Retractors diffuse. Cnidom: spirocysts, basitrichs, $\boldsymbol{p}$-mastigophores B1.

TYPE SPECIEs: Hormathia margaritacea Gosse, 1859.

VAlid SPECIES: Hormathia alba (Andres, 1881); H. andersoni Haddon, 1888; $H$. armata Rodríguez and López-González, 2001; H. castanea (McMurrich, 1904); H. coronata (Gosse, 1858); H. digitata (Müller, 1776); H. georgiana Carlgren, 1927, H. incubans (Gravier, 1918); $H$. indutus (Gravier, 1918); H. insignis (Stephenson, 1918a); H. josefi Zhiubikas, 1977; H. lacunifera (Stephenson, 1918a); H. marioni (Haddon, 


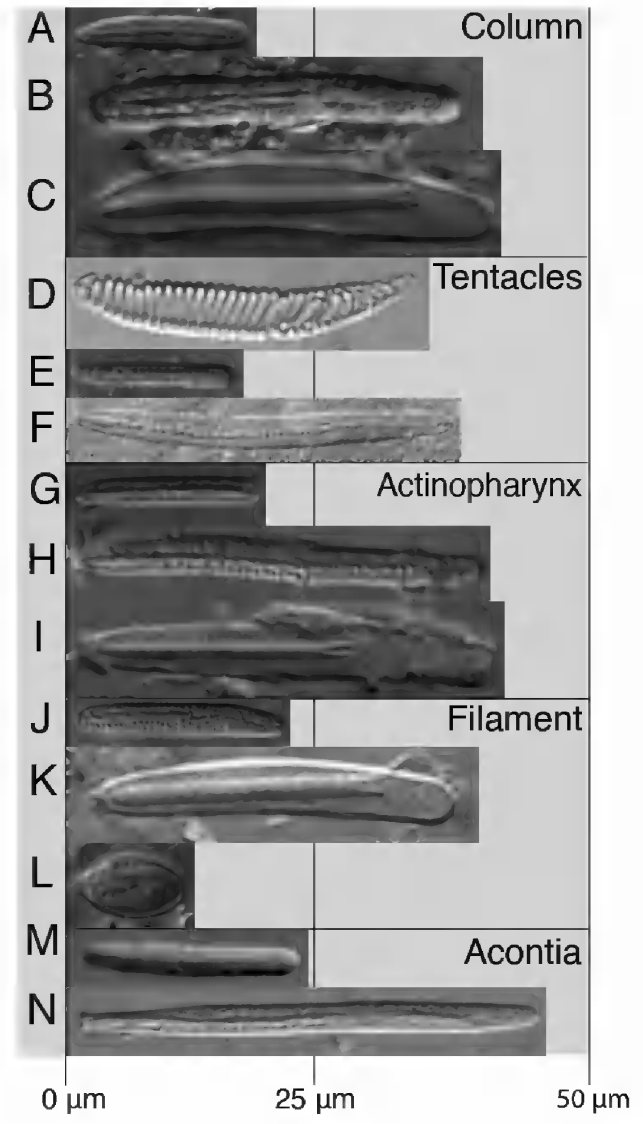

FIG. 16. Cnidom of Chondrophellia coronata (Verrill, 1883): A, B, E-H, J, M, N, basitrich; C, K, p-mastigophore $\mathrm{B} 1 ; \mathbf{D}$, spirocyst; $\mathbf{I}, p$-mastigophore A; L, scyphozoan nematocyst.

1889); H. nodosa (Fabricius, 1780); H. pacifica Sanamyan et al., 2015; H. pectinata (Hertwig, 1882); H. spinosa (Hertwig, 1882) (Fautin, 2016).

Hormathia pectinata (Hertwig, 1882)

Figures $17-18$, table 8

MATERIAL: MNRJ 6759 (3 specimens); locality: Projeto Programa Obs, Bordo da Frota Arrendada Obs Doação de Carlos M.L. Silva, CF/V Kimpo Maru, southwestern Atlantic, Brazil, off the coast of Rio Grande do Sul (RS), 3346.1' S 52 $00.03^{\prime}$ W, collected on 27 July 2002 (526 m).

MATERIAL EXAMINED: Hormathia armata: AMNH 4005 (1 specimen); locality: ANT XIX/3
Cruise, ANDEEP I Program, RV Polarstern, Sta. PS61/106-1, 61 ${ }^{\circ} 38.02^{\prime}$ S 57 $32.07^{\prime} \mathrm{W}$, Southern Ocean, Drake Passage, Antarctica, collected on 14 February 2002 (424-427 m). Hormathia lacunifera: AMNH 4106 (2 specimens); locality: ANT XIX/3 Cruise, ANDEEP I Program, RV Polarstern, Sta. PS61/049-1, 61 ${ }^{\circ} 11.57^{\prime}$ S 54 $42.99^{\prime}$ W, Southern Ocean, Antarctica, South Shetland Islands, Elephant Islands (272-306 m).

EXTERNAL ANATOMY (fig. 17): Body short and broad in preserved specimens, up to $52 \mathrm{~mm}$ in length and $58 \mathrm{~mm}$ in diameter (fig. 17A). Pedal disc flat, circular, adherent, $23 \mathrm{~mm}$ in diameter in preserved specimens (fig. 17A). Column cylindrical with deciduous cuticle (fig. 17A), often only between large tubercles (fig. 17A); tubercles smooth, distributed in entire column, regularly arranged (fig. 17A, H). Column divisible into scapus and scapulus; short capitulum not distinct, retracted into scapus in contracted preserved specimens (fig. 17A, B). Margin of capitulum tentaculate (fig. 17E). Column white in preserved specimens with brown cuticle (fig. 17A); $18 \mathrm{~mm}$ in length and $39 \mathrm{~mm}$ in diameter in preserved specimens. Oral disc circular, small, narrower than column in preserved specimens (fig. 17A). Oral disc contracted in all specimens, $10 \mathrm{~mm}$ in diameter in preserved specimens. Tentacles 92-96, short, thick, pointed, displaced to margin of oral disc.

INTERNAL ANATOMY AND HISTOLOGY (fig. 17): Body with wall thickness fairly uniform along column: epidermis and gastrodermis thinner than thick mesoglea (fig. 17E); limit between scapus and scapulus gradual (fig. 17E). Marginal sphincter musculature mesogleal, alveolar, long, narrow (fig. 17B, E); fibers in most of mesoglea, close to gastrodermis distally and scarce and narrow proximally (fig. 17B, E). Longitudinal musculature of tentacles ectodermal (fig. 17F); tentacles without mesogleal aboral thickenings (fig. 17G). Actinopharynx up to $20 \mathrm{~mm}$ in length, approximately one half of column's length; longitudinally sulcated throughout; with thick and highly glandular epidermis (not shown). Specimens with two differentiated siphonoglyphs (fig. 


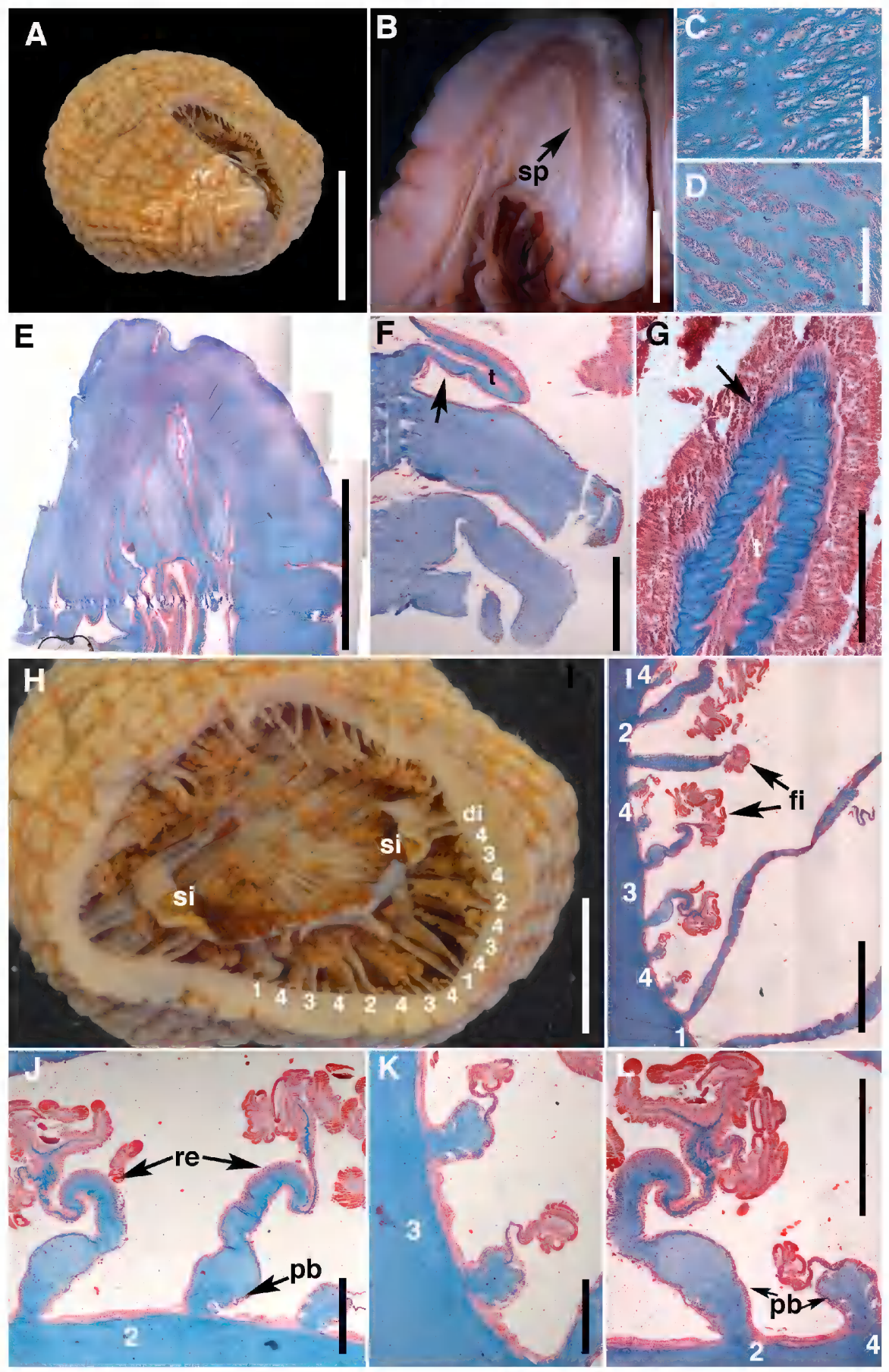


$17 \mathrm{H})$ with thin gastrodermis and epidermis and thick mesoglea.

Mesenteries hexamerously arranged in four cycles $(6+6+12+24=48$ pairs $)$ on most of body length (fig. 17H, I): at actinopharynx-level first cycle perfect, including two pairs of directives, each associated with one siphonoglyph; remaining pairs of second to fourth cycles imperfect. All mesenteries with filaments; those of first to third cycles with acontia. All examined specimens sterile. Retractors of first to third cycles well developed, diffuse (fig. 17I), restricted to distal part of mesentery (fig. 17J, K); those of fourth cycle very weak (fig. 17L). Parietobasilar musculature weak in all mesenteries, (fig. 17I-L), stronger in mesenteries of fourth cycle (fig. 17K, L). Basilar musculature of mesenteries strong (not shown).

CNidom (fig. 18): Spirocysts, basitrichs, p-mastigophores B1. See figure 18 and table 8 for size and distribution.

Distribution AND NATURAL HISTORY: Hormathia pectinata has been recorded from Chile and Argentina (Hertwig, 1882; McMurrich, 1893; Carlgren, 1959; Riemann-Zürneck, 1973) going as far north on the eastern coast of South America as the southern edge of the La Plata estuary off the coast of Mar del Plata. This species has a discontinuous distribution in the SWA (Riemann-Zürneck, 1986). Specimens of H. pec- tinata from this study were collected at a single site off the coast of Rio Grande do Sul in southern Brazil at $526 \mathrm{~m}$. This new record extends the geographic range of $H$. pectinata north of La Plata River including the southern Brazilian coast, and fall within the shallower range of the species bathymetric distribution in bathyal (405$1220 \mathrm{~m}$ ) rather than abyssal waters (2812-2925 m) (Rodríguez and López-González, 2001). Hormathia pectinata shows an overlapping geographic and bathymetric distribution only in its sub-Antarctic range with $H$. lacunifera, which is a circumpolar Southern Ocean species similarly distributed from continental shelf and bathyal depths. Hormathia spinosa (Hertwig, 1882), on the other hand, is found in sub-Antarctic region and Japan (Hertwig, 1882) whereas H. armata is known only from the Antarctic Peninsula and Weddell Sea at shallower continental waters (Rodríguez and López-González, 2013).

REMARKs: The genus Hormathia is one of the most distinctive genera of Hormathiidae and is defined by characters that have all been found in our specimens: 6 pairs of perfect and sterile mesenteries, same number of mesenteries distally and proximally, column divisible into scapus and scapulus; scapus with tubercles and cuticle; no cinclides; 96 tentacles without aboral thickenings, and absence of cuplike pedal disc.

FIG. 17. External and internal anatomy and histology of Hormathia pectinata (Hertwig, 1882). A, Oral view of preserved specimen previously dissected; note the medium-sized tubercles on column; B, longitudinal section through distal column and the short and narrow mesogleal sphincter musculature; $\mathbf{C}$, detail of alveolar arrangement of distal sphincter musculature; $\mathbf{D}$, detail of horizontally stratified alveolar arrangement of proximal sphincter musculature; E, histological longitudinal section through distal column and short, narrow mesogleal sphincter musculature; $\mathrm{F}$, longitudinal section through distal column with slight mesogleal basal aboral thickening of tentacle (arrow); G, longitudinal section through tentacle with ectodermal longitudinal musculature (arrow); $\mathbf{H}$, cross section through column at actinopharynx level with two siphonoglyphs and cycles of mesenteries (numbers); I, cross section through midcolumn showing arrangement of four cycles of mesenteries (numbers); note all mesenteries with filaments; J, cross section through midcolumn with a pair of mesenteries of second cycle with filaments; note the strong, diffuse retractor musculature and thick proximal region of mesenteries with weak parietobasilar musculature; $\mathbf{K}$, cross section through proximal column with a pair of mesenteries of third cycle with filaments; note the weak retractor musculature; $\mathbf{L}$, detail of parietobasilar musculature of second and fourth cycle mesenteries (numbers). Abbreviations: di, directive pair of mesenteries; fi, filaments; pb, parietobasilar musculature; re, retractor musculature; si, siphonoglyph; sp, marginal sphincter musculature; t, tentacle. Scale bars: A, $32 \mathrm{~mm} ; \mathbf{B}, 40 \mathrm{~mm} ; \mathbf{C}, 0.1 \mathrm{~mm} ; \mathbf{D}, \mathbf{G}, 0.2 \mathrm{~mm}$; E, $6 \mathrm{~mm}$; F, J, $0.6 \mathrm{~mm}$; H, $16 \mathrm{~mm}$; I, $2 \mathrm{~mm} ; \mathrm{K}, 0.4 \mathrm{~mm}$; $\mathrm{L}, 1 \mathrm{~mm}$. 


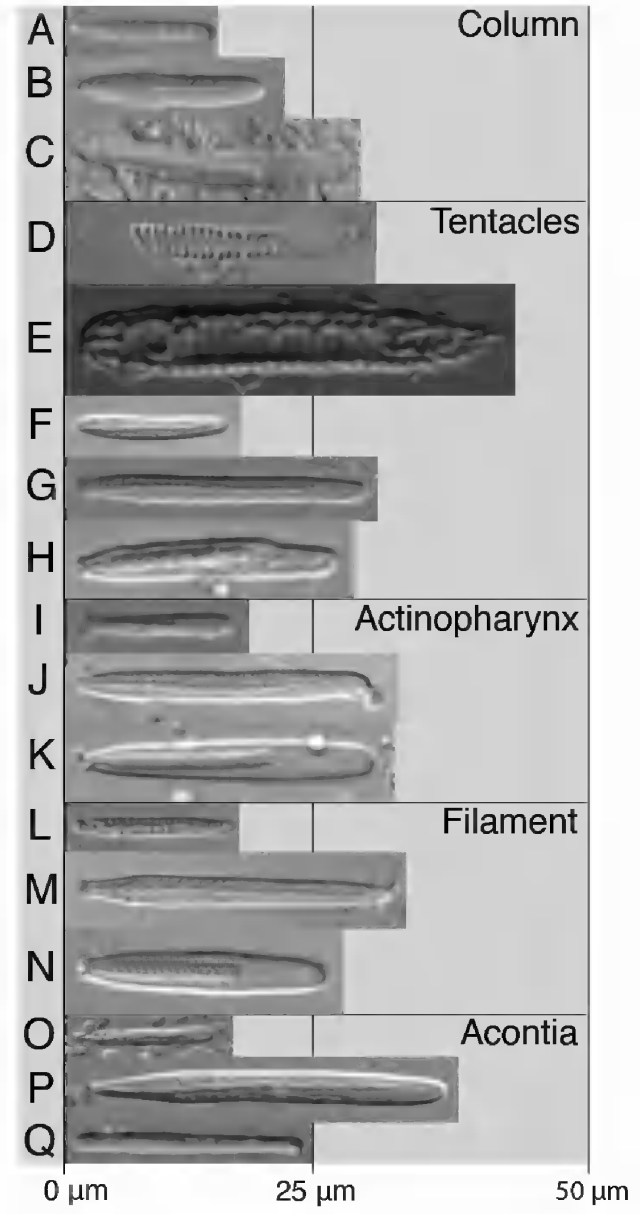

FIG. 18. Cnidom of Hormathia pectinata (Hertwig, 1882): A, B, F, G, I, J, L, M, O, P, basitrich; C, H, K, $\mathrm{N}, \mathrm{Q}$, p-mastigophore $\mathrm{B} 1 ; \mathrm{D}, \mathrm{E}$, spirocyst.

Six species of Hormathia have been recorded in the Southern Hemisphere (Dunn, 1983; Rodríguez and López-González, 2013; Fautin, 2016) though only four might be valid ( $H$. pectinata, $H$. lacunifera, $H$. spinosa, $H$. armata: Rodríguez and López-González, 2013). The anatomy and microanatomy of the individuals of $H$. pectinata examined in this study agrees with the description of Riemann-Zürneck (1973), including the number and cycles of tentacles and mesenteries. We observed the same thickening of the mesoglea in the retractors of mesenteries observed by Riemann-Zürneck (1973) (see fig. 17I-L). Unfortunately, our specimens were sterile, so we cannot comment on the fertility of the species. Though the comparative work of Riemann-Zürneck (1973) found that the taxonomic significance of the cnidon within the genus Hormathia is low, the size of basitrichs in the acontia is regarded as a distinctive character that differentiates species within the genus. Though the measurement of basitrichs in the acontia of our specimens is on the higher side of the range, it clearly identifies our specimens as $H$. pectinata and differentiates them from the remaining species of the genus in the southern Atlantic. Similar longer basitrichs in the acontia of specimens of $H$. pectinata were also found by RiemannZürneck (1973) in material from the coast of Argentina. The small size of individuals of $H$. pectinata found in Chile (type locality) might explain the particularly short basitrichs of the acontia in this material. Here, we confirm the presence of $p$-mastigophores $\mathrm{B} 1$ in relative abundance in the acontia of $H$. pectinata (fig. 18Q), which had been previously found by RiemannZürneck (1973) in H. pectinata from Argentina. This highly distinctive character further corroborates the identification of our specimens as $H$. pectinata and differentiates it from other species in the genus, and could explain the lack of a sister relationship between this species and other Hormathia spp. in all phylogenetic analyses to date (e.g., Gusmão and Daly, 2010; Rodríguez et al., 2012, 2014; Gusmão et al., 2019a, 2019b). It might also be possible that $p$-mastigophores have been overlooked in the acontia of other hormathiids and that further examination will reveal their presence in other genera or species in the family. The cnidom of our specimens agree generally with the one given by RiemannZürneck (1973) for $H$. pectinata, except that we found $p$-mastigophores B1 in the column and basitrichs in a larger category in the filaments, a difference that has been used to differentiate $H$. pectinata from $H$. armata and $H$. spinosa (E.R., personal obs.). It is possible that these large basitrichs in the filaments are the result of contamination from acontia as they overlap in size. In addition, although the $p$-mastigophores B1 


\section{TABLE 8}

Size ranges of the cnidae of Hormathia pectinata (Hertwig, 1882)

Abbreviations and symbols: $\mathrm{SD}$, standard deviation; $N$, Total number of capsules measured; $\mathrm{S}$, proportion of specimens in which each cnidae was found; $\mathrm{F}$, frequency; +++, very common; ++ , common; +, rather common; -, rare.

\begin{tabular}{|c|c|c|c|c|c|}
\hline Categories & $\begin{array}{l}\text { Range of length and width } \\
\text { of capsules }(\mu \mathrm{m})\end{array}$ & Mean \pm SD & $N$ & $\mathrm{~s}$ & $\mathbf{F}$ \\
\hline \multicolumn{6}{|l|}{ Column } \\
\hline Basitrich I (A) & $10.1-14.3 \times 1.4-2.3$ & $11.8 \pm 0.8 \times 1.8 \pm 0.2$ & 159 & $2 / 2$ & +++ \\
\hline Basitrich II (B) & $14.4-19.6 \times 2.0-3.1$ & $17.3 \pm 1.1 \times 2.6 \pm 0.2$ & 118 & $2 / 2$ & +++ \\
\hline$P$-mastigophores B1 (C) & $21.1-28.1 \times 2.3-3.8$ & $24.5 \pm 1.7 \times 2.8 \pm 0.3$ & 65 & $2 / 2$ & ++ \\
\hline \multicolumn{6}{|l|}{ Tentacles } \\
\hline Gracile spirocysts (D) & $19.4-44.9 \times 2.4-6.6$ & $32.5 \pm 5.1 \times 4.0 \pm 0.9$ & 121 & $2 / 2$ & +++ \\
\hline Robust spirocysts (E) & $21.8-44.1 \times 3.6-7.3$ & $33.4 \pm 4.0 \times 5.0 \pm 0.7$ & 45 & $2 / 2$ & ++ \\
\hline Basitrich I (F) & $12.9-36.8 \times 1.6-4.6$ & $22.6 \pm 5.4 \times 3.0 \pm 0.6$ & 98 & $2 / 2$ & +++ \\
\hline Basitrichs II (G) & $22.5-31.6 \times 1.9-3.0$ & $26.8 \pm 1.8 \times 2.4 \pm 0.2$ & 146 & $2 / 2$ & +++ \\
\hline$P$-mastigophores $\mathrm{B} 1(\mathrm{H})$ & $21.1-31.9 \times 2.8-3.7$ & $26.5 \pm 7.6 \times 3.3 \pm 0.6$ & 18 & $2 / 2$ & - \\
\hline \multicolumn{6}{|l|}{ ACTINOPHARYNX } \\
\hline Basitrichs I (I) & $11.7-19.9 \times 1.4-2.1$ & $14.6 \pm 2.7 \times 1.8 \pm 0.2$ & 42 & $2 / 2$ & - \\
\hline Basitrichs II (J) & $31.0-39.5 \times 2.7-3.7$ & $34.6 \pm 2.0 \times 3.2 \pm 0.2$ & 81 & $2 / 2$ & +++ \\
\hline$P$-mastigophores B1 I (K) & $20.7-30.2 \times 2.0-3.6$ & $26.1 \pm 1.8 \times 3.0 \pm 0.2$ & 114 & $2 / 2$ & +++ \\
\hline \multicolumn{6}{|l|}{ Filament } \\
\hline Basitrichs I (L) & $9.7-17.8 \times 1.4-2.1$ & $12.3 \pm 1.5 \times 1.7 \pm 0.2$ & 70 & $2 / 2$ & ++ \\
\hline Basitrichs II (M) & $21.8-34.1 \times 2.5-3.4$ & $31.5 \pm 2.0 \times 2.9 \pm 0.2$ & 92 & $2 / 2$ & ++ \\
\hline$P$-mastigophores $\mathrm{B} 1 \mathrm{I}(\mathrm{N})$ & $18.6-35.7 \times 2.5-3.8$ & $22.5 \pm 1.9 \times 3.1 \pm 0.2$ & 98 & $2 / 2$ & ++ \\
\hline ACONTIA & & & & $2 / 2$ & \\
\hline Basitrichs I (O) & $11.0-19.1 \times 1.5-2.2$ & $14.5 \pm 2.1 \times 1.9 \pm 0.2$ & 39 & $2 / 2$ & - \\
\hline Basitrichs II (P) & $27.2-40.8 \times 2.1-3.6$ & $34.5 \pm 1.8 \times 3.0 \pm 0.2$ & 145 & $2 / 2$ & +++ \\
\hline$P$-mastigophores B1 I (N) & $20.1-25.2 \times 2.8-4.1$ & $22.8 \pm 1.4 \times 3.3 \pm 0.3$ & 38 & $2 / 2$ & ++ \\
\hline
\end{tabular}

found in the acontia of our specimens are of similar morphology (i.e., long and thin) to those described by Riemann-Zürneck (1973) for $H$. pectinata, the size of this cnida does not overlap, ours being slightly shorter than those given by Riemann-Zürneck (1973). Our measurements for $H$. pectinata closely agree with those given by Rodríguez and López-González (2001) for the holotype of $H$. pectinata and discrepancies, particularly the longer basitrichs in the scapus of the holotype, are probably due to the small number of capsules measured by Rodríguez and
López-González (2001). Despite the known intraspecific variability in morphological characters within Hormathia (Riemann-Zürneck, 1994), including the development of tubercles (Rodríguez and López-González, 2013), the shape of the tubercles in our specimens, rounded or digitiformis (fig. 17A, H), aligning with the description of $H$. pectinata by McMurrich (1893), differentiates this species from $H$. armata and $H$. spinosa, both of which have piramidal tubercles. The corona of tubercles in our specimens is restricted to the distal scapus at the end 
of 12 longitudinal rows, which characterizes $H$. pectinata and differentiates it from $H$. armata and $H$. spinosa, whose tubercles are distributed in the entire scapus, though they are more prominent in the third most distal part of the scapus (E.R., personal obs.).

\section{Genus Phelliactis Simon, 1892}

Diagnosis (modified from Carlgren, 1949; modifications in bold): Hormathiidae with well-developed pedal disc. Body often asymmetrical. Column divisible into scapus and scapulus; scapus with weaker or stronger cuticle and numerous irregularly arranged tubercles of varying sizes. Marginal sphincter mesogleal. Tentacles more than 100, fewer than mesenteries proximally, provided with strong mesogleal basal aboral thickenings; tentacles in two more or less distinct cycles. Longitudinal muscles of tentacles ectodermal. Oral disc wide, sometimes bilobed. Two well-developed siphonoglyphs. Six to eight pairs of perfect, sterile mesenteries. Single perfect supernumerary mesenteries often paired with imperfect ones. Retractors diffuse, rather weak. Parietobasilar musculature distinct but weak. Acontia well developed. Cnidom: spirocysts, basitrichs, $\boldsymbol{p}$-mastigophores $\mathbf{B} \mathbf{1}$.

Type species: Phelliactis hertwigii Simon, 1892.

VALID SPECIES: Phelliactis algoaensis Carlgren, 1928a; $P$. americana Widersten, 1976; $P$. callicyclus Riemann-Zürneck, 1973; P. capensis Carlgren, 1938; P. capricornis Riemann-Zürneck, 1973; P. carlgreni Doumenc, 1975; P. coccinea (Stephenson, 1918b); P. crassa (Wassilieff, 1908); P. gigantea (Carlgren, 1941a); $P$. hertwigii; $P$. hydrothermala Sanamyan and Sanamyan, 2007; $P$. incerta Carlgren, 1934; $P$. japonica (Wassilieff, 1908); P. lophohelia Riemann-Zürneck, 1973; $P$. magna (Wassilieff, 1908); P. pelophila RiemannZürneck, 1973; P. pulchra (Stephenson, 1918b); P. robusta Carlgren, 1928b; P. siberutiensis Carlgren, 1928a; P. somaliensis Carlgren, 1928a; Phelliactis yapensis $\mathrm{Li}$ and $\mathrm{Xu}, 2016$.
Phelliactis capricornis Riemann-Zürneck, 1973

Figures 19-20, table 9

MATERIAL: MNRJ 4165 (1 specimen); locality: REVIZEE Bahia 2, R/V Thalassa, Sta. e0500, sector 1 , arrest 6 , southwestern Atlantic, Brazil, off the coast of Bahia, $13^{\circ} 22.95^{\prime} \mathrm{S} 38^{\circ} 43.4^{\prime} \mathrm{W}$, collected on 8 June 2000 (394 m). MNRJ 4166 (3 specimens); locality: REVIZEE Bahia 2, R/V Thalassa, Sta. e0517, sector 1, arrest 6, southwestern Atlantic, Brazil, off the coast of Bahia, $13^{\circ} 24.55^{\prime} \mathrm{S} 38^{\circ} 38.88^{\prime} \mathrm{W}$, collected on 19 June 2000 (750 m). MNRJ 4167 (4 specimens); locality: REVIZEE Bahia 2, R/V Thalassa, Sta. e0499, sector 1, arrest 5, southwestern Atlantic, Brazil, off the coast of Bahia, $13^{\circ} 36.77^{\prime} \mathrm{S} 38^{\circ} 46.02^{\prime} \mathrm{W}$, collected on 8 June 2000 (761 m).

Material eXAmined: Phelliactis robusta: ZMUC ANT-000014 (1 specimen; syntype); locality: Ingolf Expedition, Sta. ING032, Arctic Ocean, Davis Strait, $66^{\circ} 35.0^{\prime} \mathrm{N} 56^{\circ} 38.0^{\prime} \mathrm{W}$, collected 11 July 1896 (599 m). Phelliactis americana: USNM 54323 (1 specimen; Holotype); locality: RV Delaware, North Atlantic Ocean, United States, off New Jersey, collected on 19 February 1963, ID by B. Widersten on 15 September 1975 (366 m). Phelliactis capricornis: ZMH C7547 (1 specimen; holotype); locality: Walther-Herwig Expedition, Sta. 85, Southwest Atlantic, Brazil, about $200 \mathrm{~km}$ off the State of São Paulo, $25^{\circ} 13.2^{\prime}$ S $44^{\circ} 33.0^{\prime} \mathrm{W}$ $(1200 \mathrm{~m})$. Phelliactis incerta: MZB 39198 (1 specimen; holotype); locality: Michael Sars North Atlantic Deep-sea Expedition 1910, Sta. 23, Atlantic Ocean, near Strait of Gibraltar, $35^{\circ} 31.8^{\prime} \mathrm{S}$ $7^{\circ} 07.2^{\prime} \mathrm{W}(1215 \mathrm{~m})$

External ANATOMy (fig. 19): Preserved specimens $53-78 \mathrm{~mm}$ in length and $32-54 \mathrm{~mm}$ in diameter (fig. 19A). Pedal disc irregularly shaped, slightly broader than column, $32-88 \mathrm{~mm}$ in diameter in preserved specimens (fig. 19A). Column cylindrical, with large tubercles from proximal to distal column (fig. 19A); in some specimens tubercles larger in distal column (fig. 19B). Column divisible into long scapus and short capitulum (fig. 18A); capitulum smooth, visibly distinct in contracted preserved speci- 


\section{TABLE 9}

Size ranges of the cnidae of Phelliactis capricornis Riemann-Zürneck, 1973

Abbreviations and symbols: SD, standard deviation; $N$, Total number of capsules measured;

$S$, proportion of specimens in which each cnidae was found; F, frequency; +++, very common; ++ , common; +, rather common; -, rare.

\begin{tabular}{|c|c|c|c|c|c|}
\hline Categories & $\begin{array}{l}\text { Range of length and width of } \\
\text { capsules }(\mu \mathrm{m})\end{array}$ & Mean \pm SD & $N$ & $S$ & $\mathbf{F}$ \\
\hline \multicolumn{6}{|l|}{ Column } \\
\hline Basitrichs I (A) & $09.7-22.3 \times 1.6-3.1$ & $16.4 \pm 2.8 \times 2.6 \pm 0.4$ & 53 & $5 / 5$ & ++ \\
\hline Basitrichs II (B) & $37.0-49.3 \times 2.8-4.0$ & $42.8 \pm 4.5 \times 3.3 \pm 0.4$ & 8 & $2 / 5$ & - \\
\hline$P$-mastigophores B1 (C) & $31.4-47.3 \times 3.7-4.8$ & $35.5 \pm 3.7 \times 4.1 \pm 0.3$ & 16 & $2 / 5$ & - \\
\hline \multicolumn{6}{|l|}{ Tentacles } \\
\hline Gracile spirocysts (D) & $21.3-53.7 \times 2.8-6.7$ & $36.3 \pm 6.8 \times 4.7 \pm 0.9$ & 213 & $5 / 5$ & +++ \\
\hline Robust spirocysts (E) & $31.3-69.2 \times 4.7-11.3$ & $51.6 \pm 6.8 \times 6.9 \pm 1.3$ & 192 & $5 / 5$ & +++ \\
\hline Basitrichs I (F) & $14.6-29.4 \times 1.6-4.4$ & $21.8 \pm 4.6 \times 2.8 \pm 0.7$ & 43 & $5 / 5$ & ++ \\
\hline Basitrichs II (G) & $26.5-54.8 \times 2.4-7.8$ & $39.1 \pm 4.9 \times 3.4 \pm 0.8$ & 137 & $5 / 5$ & +++ \\
\hline$P$-mastigophores B1 I $(\mathrm{H})$ & $31.0-49.0 \times 3.5-6.9$ & $37.7 \pm 7.0 \times 4.3 \pm 1.1$ & 8 & $2 / 5$ & - \\
\hline \multicolumn{6}{|l|}{ ACTINOPHARYNX } \\
\hline Basitrichs I (I) & $16.1-23.8 \times 1.6-2.6$ & $19.1 \pm 2.1 \times 2.1 \pm 0.2$ & 56 & $5 / 5$ & ++ \\
\hline Basitrichs II (J) & $29.0-51.6 \times 2.4-6.2$ & $38.3 \pm 3.8 \times 3.3 \pm 0.2$ & 319 & $5 / 5$ & +++ \\
\hline$P$-mastigophores B1 I (K) & $27.2-46.6 \times 2.9-4.8$ & $37.9 \pm 3.8 \times 4.0 \pm 0.4$ & 200 & $5 / 5$ & +++ \\
\hline \multicolumn{6}{|l|}{ Filament } \\
\hline Basitrichs I (L) & $12.0-38.6 \times 1.5-3.0$ & $17.9 \pm 4.2 \times 2.0 \pm 0.2$ & 176 & $5 / 5$ & +++ \\
\hline Basitrichs II (M) & $34.5-47.4 \times 2.2-4.2$ & $40.9 \pm 2.4 \times 2.9 \pm 0.2$ & 101 & $5 / 5$ & ++ \\
\hline P-mastigophores B1 I (N) & $25.1-41.2 \times 2.8-5.5$ & $29.7 \pm 3.3 \times 3.7 \pm 0.3$ & 298 & $5 / 5$ & +++ \\
\hline Agaricyst $(\mathrm{O})$ & $11.3-30.1 \times 4.4-6.6$ & $23.4 \pm 7.3 \times 5.0 \pm 0.6$ & 17 & $2 / 5$ & - \\
\hline ? contamination $(\mathrm{P})$ & $30.1-83.7 \times 3.1-7.9$ & $43.6 \pm 10.4 \times 5.5 \pm 1.0$ & 27 & $2 / 5$ & - \\
\hline \multicolumn{6}{|l|}{ ACONTIA } \\
\hline Basitrichs I (Q) & $13.6-27.6 \times 1.4-3.0$ & $20.3 \pm 3.0 \times 2.0 \pm 0.2$ & 168 & $6 / 6$ & ++ \\
\hline Basitrichs II (R) & $29.1-53.7 \times 2.3-3.8$ & $44.4 \pm 2.3 \times 2.8 \pm 0.2$ & 517 & $6 / 6$ & +++ \\
\hline
\end{tabular}

mens (fig. 19B, C). Margin of capitulum tentaculate (fig. 19C). Column white or beige in preserved specimens, with deciduous cuticle remaining only in spaces between tubercles (fig. 19A). Column 53-78 $\mathrm{mm}$ in length and 32-54 $\mathrm{mm}$ in diameter in preserved specimens. Oral disc irregularly shaped, wider than column, bilobed (fig. 19A, B); 19-44 $\mathrm{mm}$ in diameter in preserved specimens. Tentacles 173-180, smooth, short, slender and pointed, in six cycles $(6+6+12+24+48+n)$, displaced to margin of oral disc (fig. 19C). All tentacles of same size, white or beige in preserved specimens (fig. 19B, C); longest tentacle up to $10 \mathrm{~mm}$. Mesogleal basal aboral thickening of tentacles visible in preserved specimens (fig. 19C).

INTERNAL ANATOMY AND HISTOLOGY (fig. 19): Marginal sphincter musculature mesogleal (fig. 19D). Longitudinal musculature of tentacles ectodermal (figs. 19E); mesogleal basal aboral thickenings in every outer tentacle (fig. 19F). Actinopharynx up to $35 \mathrm{~mm}$ in length, approxi- 

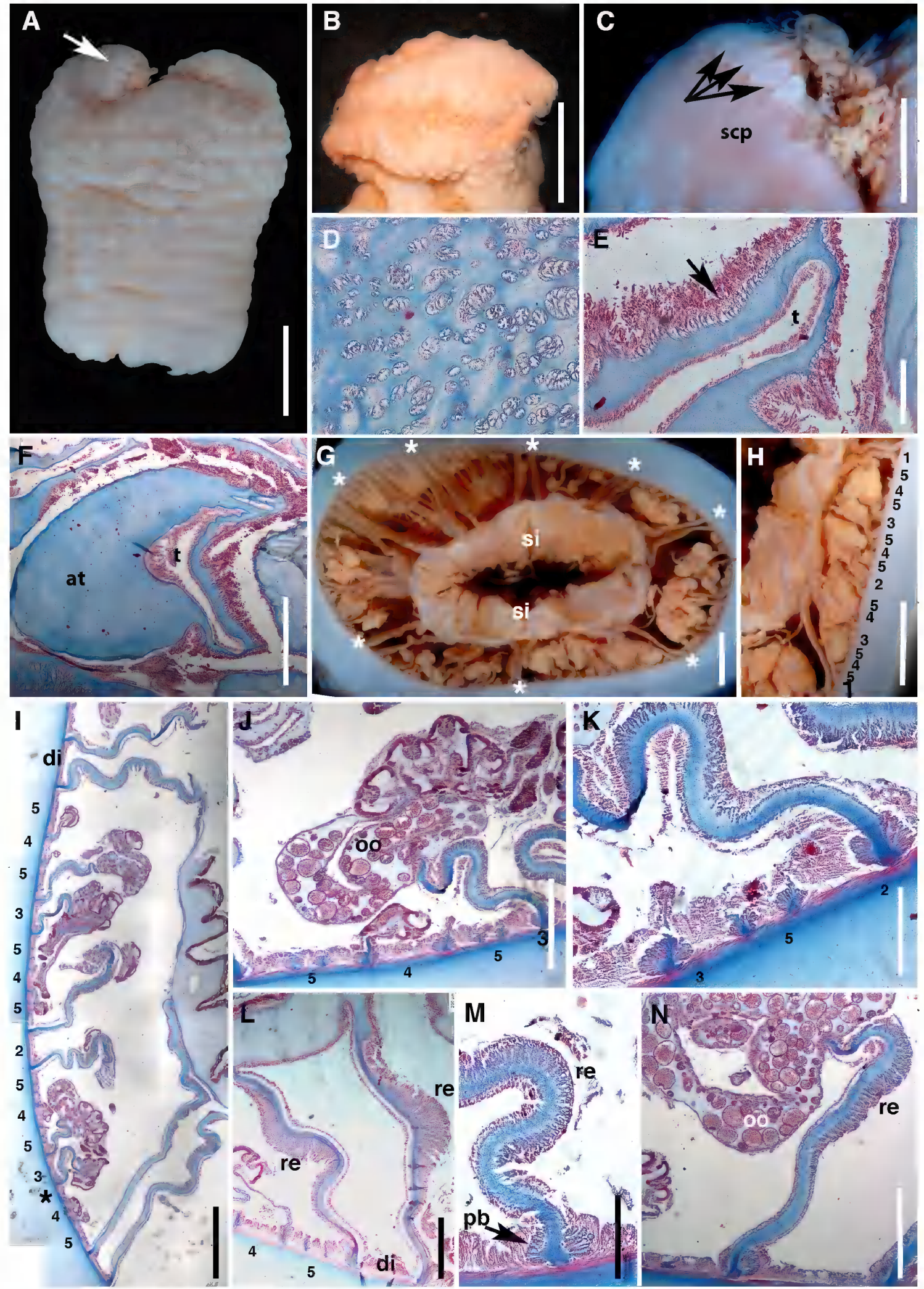

$\mathrm{N} 20.200 \%$
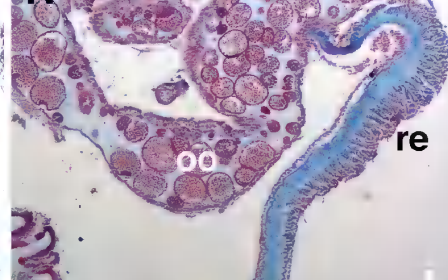
was established based on only two specimens one of which showed empty ovarian follicles (Riemann-Zürneck, 1973) and the presence of gametogenic tissue on the second and third cycles of mesenteries could be clearly confirmed in our material (see fig. 19I, J) we assume this difference is due to such difficulties.

\section{Phelliactis pelophila Riemann-Zürneck, 1973}

Figures 21-22, table 10

MATERIAL: MNRJ 4227 (2 specimens); locality: REVIZEE Bahia 2, R/V Thalassa, Sta. EO523, sector 1, dredging 29, southwestern Atlantic, Brazil, off the coast of Espirito Santo (ES), 19 ${ }^{\circ} 51.48^{\prime} \mathrm{S}$ $38^{\circ} 32.5^{\prime} \mathrm{W}$, collected on 27 June 2000 (922 m). MNRJ 4358 (2 specimens); locality: REVIZEE Central 1, R/V Thalassa, southwestern Atlantic, Brazil, off the coast of Rio de Janeiro (RJ), $21^{\circ} 56.27^{\prime} \mathrm{S} 40^{\circ} 09.98^{\prime} \mathrm{W}$, collected on 22 June 2000 (? m). MNRJ 6783 (2 specimens); locality: Projeto Programa Obs, Bordo da Frota Arrendada Obs Doação de Carlos M.L. Silva, CF/V Kimpo Maru, southwestern Atlantic, Brazil, off the coast of Rio Grande do Sul (RS), $33^{\circ} 46.1^{\prime} \mathrm{S} 52^{\circ} 0.03^{\prime} \mathrm{W}$, collected on 27 July 2002 (526 m).

Material examined: Phelliactis lophohelia: ZMH CZ7542 (1 specimen; holotype); locality:
Walther-Herwig Expedition, southwestern Atlantic Ocean, between $22^{\circ}-38^{\circ} \mathrm{S}$, collected between 22 February 1968 and 15 March 1968 $(800 \mathrm{~m})$. Phelliactis gigantea: ZMUC ANT000029 (1 specimen; holotype); locality: Th. Mortensen's Java-South Africa Expedition, St. 80A, tropical east Atlantic, St. Helena, $3 \mathrm{~km}$ SE of Longe Range Point, collected on 24 February 1930 by Th. Mortensen, "Dana" (360 m).

External ANATOMY (fig. 21): Body long and flattened at directive axis in preserved specimens (fig. 21A). Pedal disc curved, flattened at directive axis, $16-110 \mathrm{~mm}$ in diameter in preserved specimens (fig. 21A). Column flattened at directive axis, covered by cuticle (fig. 21A) often only in area between tubercles (fig. 21A, B); tubercles not pointed but smooth (fig. 21A, C). Column visibly divisible into scapus and short capitulum in preserved specimens (fig. 21A). Margin of capitulum tentaculate (fig. 21C). Column white in preserved specimens with cuticle olive green (fig. 21A). Column 42-71 $\mathrm{mm}$ in diameter and 52-104 $\mathrm{mm}$ in length in preserved specimens. Oral disc large, clearly bilobed, wider than column in preserved specimens (fig. 21A); 32-52 $\mathrm{mm}$ in diameter in preserved specimens. Tentacles 171-182, short, slender and pointed, displaced to margin of oral disc but contracted within oral disc.

FIG. 19. External and internal anatomy and histology of Phelliactis capricornis Riemann-Zürneck, 1973. A, Lateral view of preserved specimen, tubercles on column, characteristic bilobed oral disc with tentacles with basal aboral thickenings (arrow); B, lateral view of preserved specimen, tubercles on distal column and smooth scapulus; C, detail of smooth scapulus with tentacles with basal aboral thickenings (arrows); D, detail of alveolar arrangement of mesogleal sphincter musculature; E, longitudinal section through tentacle with ectodermal musculature (arrow); F, longitudinal section through tentacle with mesogleal basal aboral thickening; G, cross section through midcolumn at the actinopharynx level and five cycles of mesenteries; note eight perfect pairs of mesenteries (asterisks) and two siphonoglyphs; $\mathbf{H}$, detail of a cross section showing the cycles of mesenteries (numbers); note the absence of a pair of fifth cycle (asterisk); I, histological cross section through midcolumn at actinopharynx level showing five cycles of mesenteries; note missing fifth cycle (asterisk); J, cross section through midcolumn with two pairs of fifth cycle without retractors, filament, or gametogenic tissue, one pair of fourth cycle with filament only, and one mesentery of third cycle with filament and gametogenic tissue; $\mathbf{K}$, detail of one mesentery of third cycle, one pair of fifth cycle and one mesentery of second cycle; $\mathbf{L}$, detail of a pair of directive mesenteries with diffuse retractor musculature; $\mathbf{M}$, detail of strong parietobasilar musculature of a mesentery of first cycle; $\mathbf{N}$, detail of a mesentery of first cycle with strong, diffuse retractor and strong parietobasilar musculature with gametogenic tissue. Abbreviations: mat, mesogleal aboral thickening; di, directive pair of mesenteries; oo, oocytes; pb, parietobasilar musculature; re, retractor musculature; scp, scapulus; t, tentacle. Scale bars: A, B, $20 \mathrm{~mm}$; C, $10 \mathrm{~mm}$; D, E, J-N, $0.25 \mathrm{~mm}$; F-I, $1 \mathrm{~mm}$. 


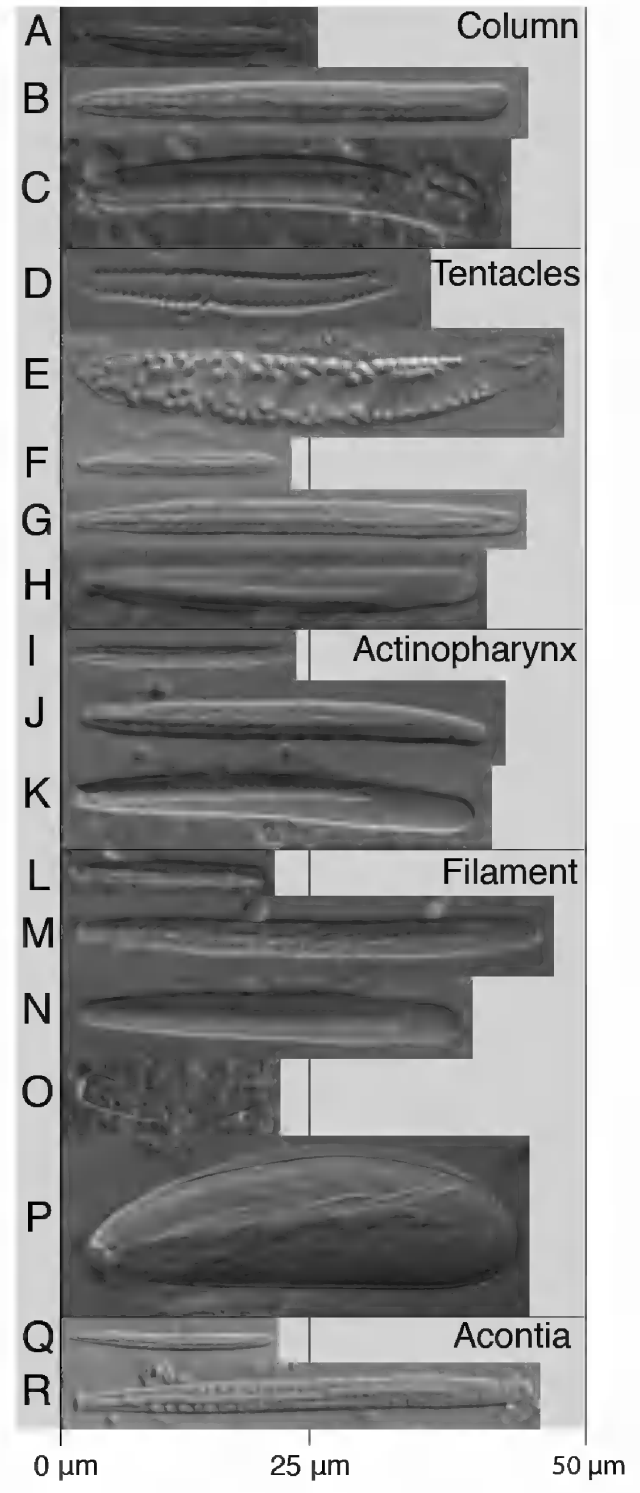

FIG. 20. Cnidom of Phelliactis capricornis RiemannZürneck, 1973: A, B, F, G, I, J, L, M, Q, R, basitrich; $\mathrm{C}, \mathrm{H}, \mathrm{K}, \mathbf{N}$, p-mastigophore $\mathrm{B} 1 ; \mathrm{D}, \mathrm{E}$, spirocyst; $\mathbf{O}$, agarocystlike; $\mathbf{P}$, undetermined nematocyst.

INTERNAL ANATOMY AND Histology (fig. 21): Body with wall thickness fairly uniform along column: epidermis and gastrodermis thinner than thick mesoglea (fig. 21C); limit between scapus and capitulum gradual. Marginal sphincter musculature mesogleal, long, narrow, equidistant from epidermis and gastrodermis (fig.
21C); fibers with alveolar arrangement (fig. 21D). Column with "spongy" texture in some areas (fig. 21E). Longitudinal musculature of tentacles ectodermal (fig. 21F); all tentacles with mesogleal basal aboral thickenings (fig. 21G). Actinopharynx up to $30 \mathrm{~mm}$ in length, approximately half of column's length; longitudinally sulcated throughout; with thick and highly glandular epidermis (not shown). Specimens with two differentiated siphonoglyphs with thin gastrodermis and epidermis and thick mesoglea (fig. 21H).

Mesenteries mostly hexamerously arranged in five cycles $(6+6+12+24+37=85$ pairs $)$ in most of body length: at actinopharynx-level first cycle perfect, including two pairs of directives, each associated with one siphonoglyph (fig. $21 \mathrm{H}$ ); two or three additional pairs of mesenteries of second cycle perfect. Remaining pairs of second to fifth cycles imperfect (fig. $21 \mathrm{H}$ ). Specimens with irregularities in arrangement of mesenteries including 9 missing pairs of fifth cycle (asterisks: fig. $21 \mathrm{H}$ ); missing pairs of fifth cycle always close to pairs of third cycle. Mesenteries of first to fourth cycles, including directives, with filaments; those of second to fourth cycles fertile (fig. 21H, I). Retractors of first to third cycles strong, diffuse (fig. $21 \mathrm{H}-\mathrm{J}$ ); those of fourth cycle weak (fig. 21I) and those of fifth cycle absent (fig. 21J). Parietobasilar musculature strong in all mesenteries (fig. 21I, J). Species gonochoric: major axis of oocytes $70-189 \mu \mathrm{m}$ in diameter (fig. 21I); major axis of spermatic cysts 126-549 $\mu \mathrm{m}$ in diameter (fig. $21 \mathrm{~L}$ ) in specimens collected in June. Basilar musculature of mesenteries weak (not shown).

CNidom (fig. 22): Spirocysts, basitrichs, p-mastigophores B1. See figure 22 and table 10 for size and distribution of cnidae.

Distribution AND NATURAL HISTORY: Phelliactis pelophila is widely distributed in Brazil, including the Espirito Santos Basin and the Campos Basin in the southeastern region and the Pelotas Basin in the southernmost state of Rio Grande do Sul. All of the specimens collected in Brazil represent a range extension for $P$. pelophila that had previously 
been collected only off the coast of Uruguay (Riemann-Zürneck, 1973). Our records extend the bathymetric range of the species to relatively shallower waters (526-922 m) compared to the type material (800-1000 m: RiemannZürneck, 1973).

REMARKs: The eight (MZUSP 4227, MZUSP 4358) or nine (MZUSP 6783) pairs of perfect mesenteries, the relatively small and flat tubercles on column, the gametogenic tissue present on third and fourth cycles of mesenteries, $p$-mastigophores B1 in the tentacles as well as similar retractor, parietobasilar and marginal sphincter musculature of our specimens agree perfectly to the description of Phelliactis pelophila by Riemann-Zürneck (1973). Again, the only major difference between the type material of $P$. pelophila and our specimens is the fertility pattern: gametogenic tissue only on mesenteries of fourth cycle in type material and gametogenic tissue on mesenteries of third and fourth in our specimens (see fig. 21H).

\section{KEY TO THE DEEP-SEA SPECIES OF ANEMONES OFF THE COAST OF BRAZIL}

1. Small elongate body with rounded aboral end; marginal sphincter and basilar musculature absent, mesenteries divisible into macro- and microcnemes; always eight macrocnemes.

- Flatenned pedal disc, marginal sphincter and basilar musculature present; mesenteries not divisible into macro- and microcnemes......3

2. Retractor musculature with pennon, basitrichs in actinopharynx $26.7-46.2 \mu \mathrm{m}$ Isoscolanthus janainae

- Retractor musculature without pennon, basitrichs in actinopharynx 50.7-100.1 $\mu \mathrm{m}$........ Isoscolanthus iemanjae

3. Without acontia.........Actinoscyphia saginata

- With acontia ....................................................... 4

4. First cycle of mesenteries fertile ....................5

- First cycle of mesenteries sterile ...................6
5. First cycle with six perfect pairs; same number of mesenteries distally and proximally; column with tubercles

Chondrophellia coronata

- First cycle with 10 perfect pairs; more mesenteries proximally; column smooth Amphianthus lacteus

6. Extremely flattened body; $<32$ tentacles; acontia inconspicuous or completely absent .Monactis vestita

- Nonflattened body; >48 tentacles; acontia always present, abundant .7

7. Same number of mesenteries distally and proximally . .8

- Different number of mesenteries distally and proximally . .9

8. Pedal disc cuplike, often filled with mud .....

- Pedal disc never cuplike Actinauge longicornis Hormathia pectinata

9. Tentacles without basal aboral mesogleal thickenings .................Paraphelliactis labiata

- Tentacle with basal aboral mesogleal thickenings . .10

10. Only six pairs of perfect mesenteries Phelliactis robusta

- More than six pairs of perfect mesenteries ....11

11. 12 pairs of perfect mesenteries Phelliactis lophohelia

- Eight or nine pairs of perfect mesenteries ... . .12

12 Eight or nine pairs of perfect mesenteries; second and third cycles fertile

Phelliactis capricornis

- Eight pairs of perfect mesenteries; second to fourth cycles fertile ........Phelliactis pelophila

\section{DISCUSSION}

We provided complete descriptions, images of external and internal anatomy, microanatomy, cnidae, and geographic distribution for 10 species, including a species new to science, Actinernus mercedae. Our study raises the diversity of deep-sea anemones from Brazil from eight species to 12 (see table 11) and the 


\section{TABLE 10}

Size ranges of the cnidae of Phelliactis pelophila Riemann-Zürneck, 1973

Abbreviations and symbols: SD, standard deviation; $N$, Total number of capsules measured; $S$, proportion of specimens in which each cnidae was found; F, frequency; +++, very common; ++ , common; +, rather common; -, rare.

\begin{tabular}{|c|c|c|c|c|c|}
\hline Categories & $\begin{array}{l}\text { Range of length and width of } \\
\text { capsules }(\mu \mathrm{m})\end{array}$ & Mean \pm SD & $N$ & $S$ & $\mathbf{F}$ \\
\hline \multicolumn{6}{|l|}{ Column } \\
\hline Basitrich I (A) & $10.6-14.7 \times 1.7-2.4$ & $13.0 \pm 0.9 \times 2.0 \pm 0.2$ & 44 & $3 / 3$ & + \\
\hline Basitrich II (B) & $17.9-23.9 \times 2.8-3.8$ & $21.3 \pm 1.5 \times 3.5 \pm 0.3$ & 74 & $3 / 3$ & ++ \\
\hline$P$-mastigophores B1 (C) & $28.0-42.2 \times 2.0-6.7$ & $33.8 \pm 2.5 \times 5.2 \pm 0.5$ & 120 & $3 / 3$ & +++ \\
\hline \multicolumn{6}{|l|}{ Tentacles } \\
\hline Spirocysts (D-E) & $33.7-72.6 \times 3.3-9.7$ & $52.1 \pm 8.6 \times 6.1 \pm 1.4$ & 243 & $3 / 3$ & +++ \\
\hline Basitrichs (F-G) & $18.3-48.6 \times 2.1-3.6$ & $39.0 \pm 8.9 \times 3.1 \pm 0.4$ & 24 & $3 / 3$ & + \\
\hline$P$-mastigophores $\mathrm{B} 1(\mathrm{H})$ & $35.7-52.5 \times 4.0-5.8$ & $46.7 \pm 4.8 \times 4.8 \pm 0.6$ & 12 & $3 / 3$ & + \\
\hline \multicolumn{6}{|l|}{ ACTINOPHARYNX } \\
\hline Basitrichs I (I) & $17.0-29.4 \times 1.9-3.2$ & $21.4 \pm 2.1 \times 2.3 \pm 0.3$ & 40 & $3 / 3$ & + \\
\hline Basitrichs II (J) & $39.5-52.9 \times 3.0-4.3$ & $46.8 \pm 2.9 \times 3.6 \pm 0.3$ & 178 & $3 / 3$ & +++ \\
\hline P-mastigophores B1 I (K) & $31.9-45.9 \times 4.1-5.1$ & $38.1 \pm 3.3 \times 4.6 \pm 0.3$ & 75 & $3 / 3$ & ++ \\
\hline \multicolumn{6}{|l|}{ FILAMENT } \\
\hline Basitrichs I (L) & $15.4-27.4 \times 1.8-2.9$ & $19.8 \pm 2.5 \times 2.3 \pm 0.2$ & 183 & $3 / 3$ & +++ \\
\hline Basitrichs II (M) & $35.5-46.2 \times 3.1-3.6$ & $43.5 \pm 1.8 \times 3.4 \pm 0.2$ & 31 & $3 / 3$ & - \\
\hline$P$-mastigophores B1 I (N) & $31.1-39.0 \times 3.2-4.9$ & $36.0 \pm 2.0 \times 4.0 \pm 0.3$ & 176 & $3 / 3$ & ++ \\
\hline \multicolumn{6}{|l|}{ ACONTIA } \\
\hline Basitrichs I (O) & $13.8-27.1 \times 1.0-2.8$ & $18.8 \pm 2.7 \times 1.9 \pm 0.3$ & 47 & $3 / 3$ & ++ \\
\hline Basitrichs II (P) & $41.8-54.6 \times 2.7-3.5$ & $47.3 \pm 2.1 \times 3.1 \pm 0.2$ & 257 & $3 / 3$ & +++ \\
\hline
\end{tabular}

FIG. 21. External and internal anatomy and histology of Phelliactis pelophila Riemann-Zürneck, 1973. A, Lateral view of preserved specimen showing prominent tubercles on column and cuticle; $\mathbf{B}$, cross section through midcolumn with thick mesogleal, thin epidermis, and layered cuticle; $\mathbf{C}$, longitudinal section through distal column with long marginal mesogleal sphincter musculature; $\mathbf{D}$, detail of alveolar arrangement of sphincter musculature; E, cross section through midcolumn showing "spongy" aspect with thick mesogleal, thin epidermis, and cuticle; F, longitudinal section through tentacle with ectodermal musculature (arrow); G, longitudinal section through tentacle with mesogleal basal aboral thickening; $\mathbf{H}$, cross section through midcolumn below actinopharynx and cycles of mesenteries (numbers); note missing pairs of fifth cycle (asterisks); I, detail of one pair of mesenteries of fifth cycle without retractors, filament, or gametogenic tissue and one pair of mesenteries of fourth cycle with retractor and parietobasilar musculatures and gametogenic tissue; $\mathbf{J}$, detail of parietobasilar musculature (arrow); K, detail of acontia with basitrichs (arrows); L, detail of spermatic cysts Abbreviations: cu, cuticle; di, directive pair of mesenteries; ep, epidermis; mat, mesogleal aboral thickening; me, mesoglea; oo, oocytes; pb, parietobasilar musculature; sc, spermatic cyst; si, siphonoglyph; sp, marginal sphincter musculature. Scale bars: A, $40 \mathrm{~mm}$; B, D, F, G, K, L, $0.4 \mathrm{~mm}$; C, H, $6 \mathrm{~mm}$; E, I, $0.8 \mathrm{~mm}$; J, $1 \mathrm{~mm}$. 

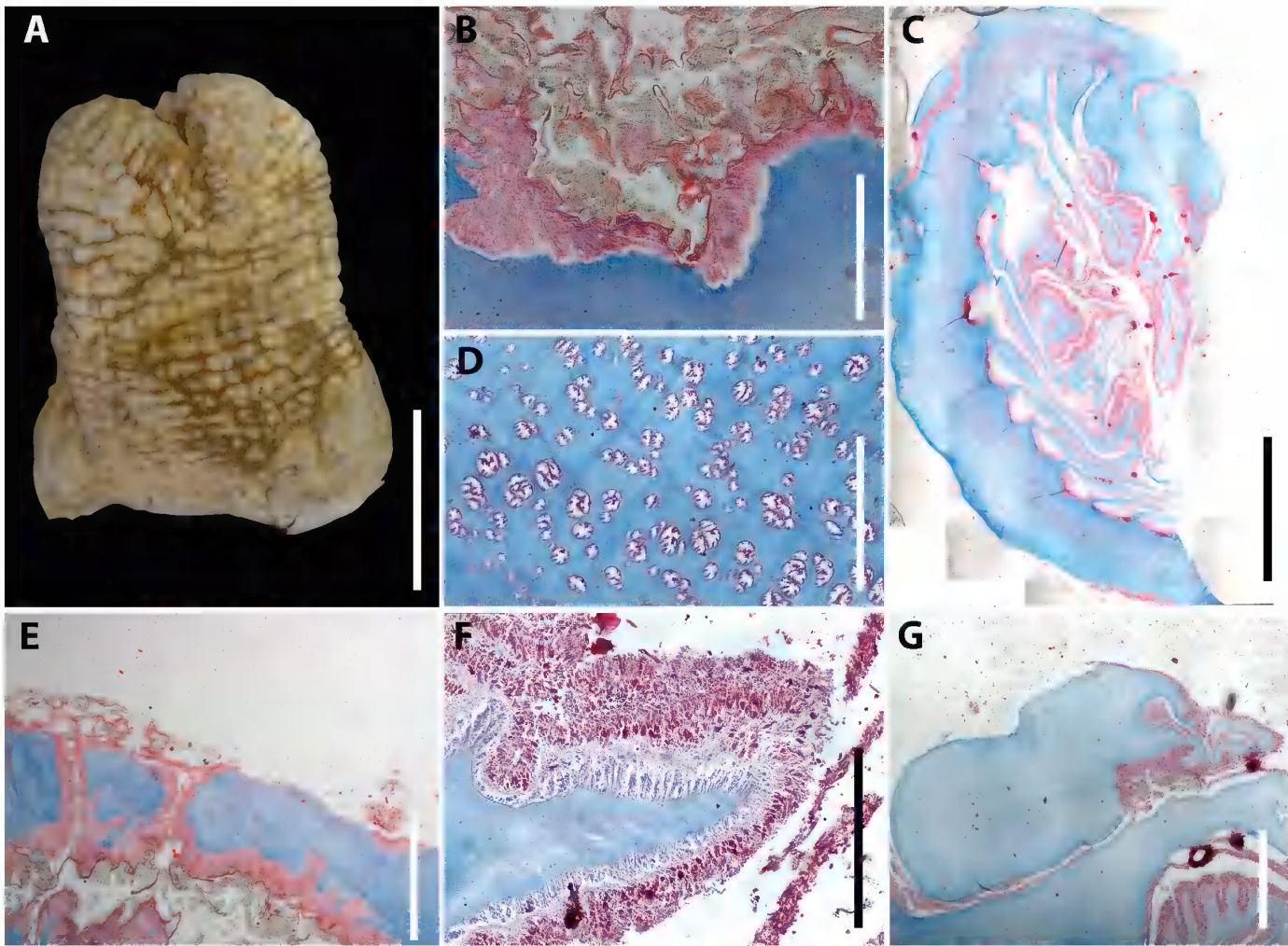

$\mathbf{G}$

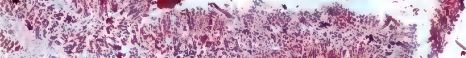
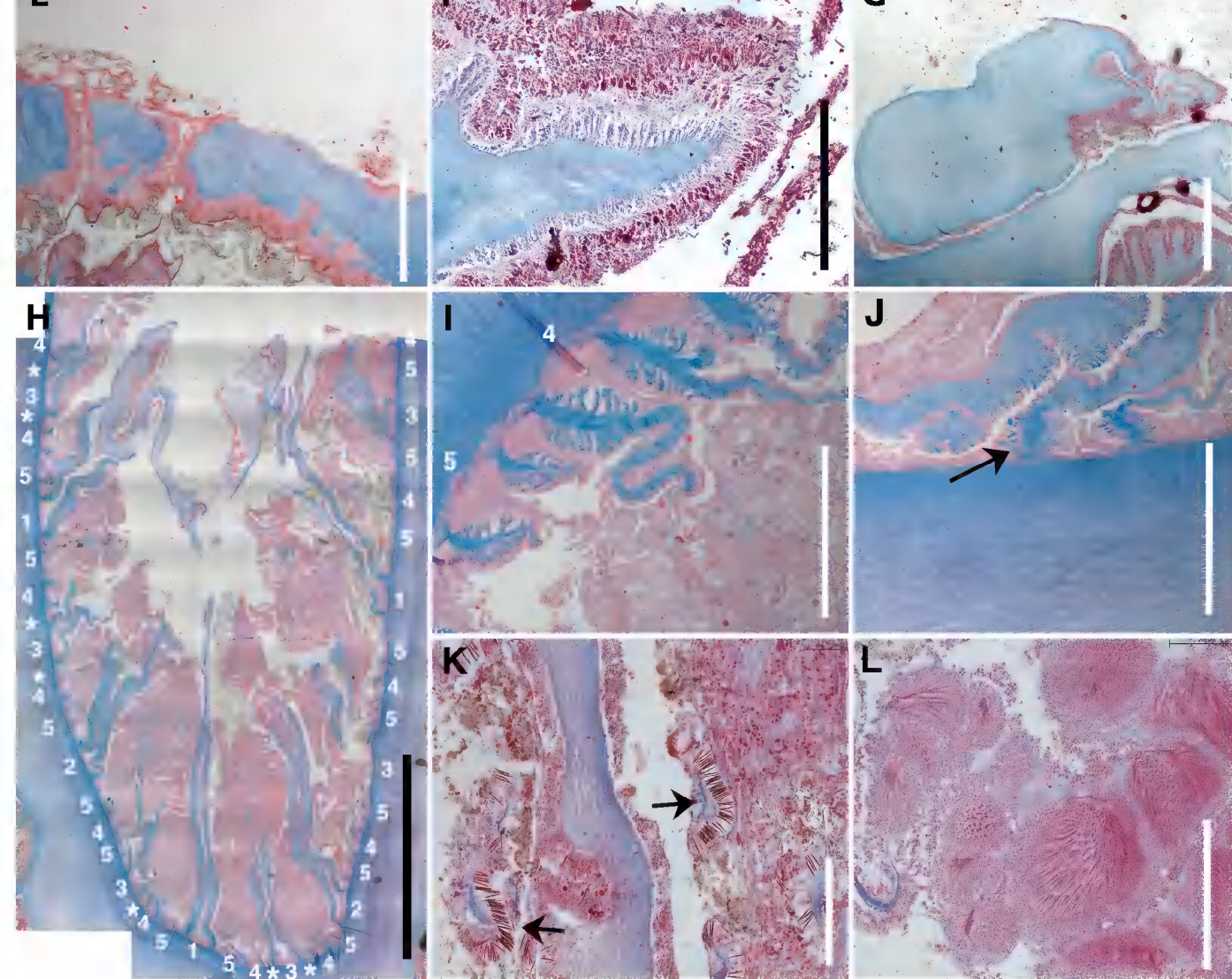


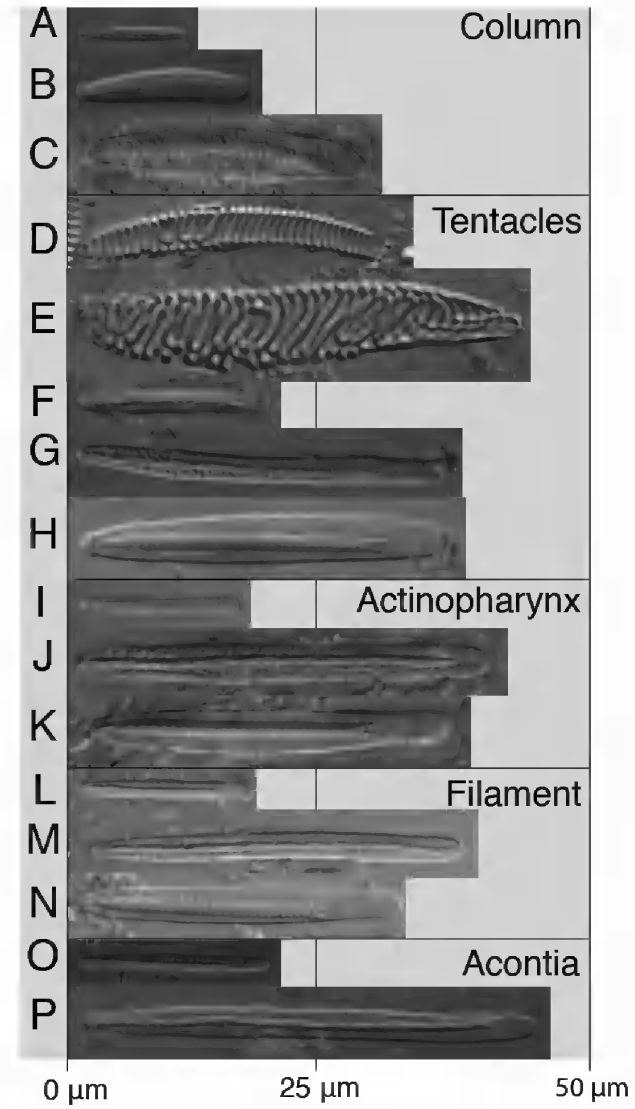

FIG. 22. Cnidom of Phelliactis pelophila RiemannZürneck, 1973: A, B, F, G, I, J, L, M, O, P, basitrich; C, H, K, N, p-mastigophore B1; D, E, spirocyst.

total number of species known from Brazilian waters to 63 (table 12). Six species were recorded along the southeastern Brazilian coast, two of which are considered deep-sea endemics to Brazil (i.e., Phelliactis capricornis and P. pelophila) (Riemann-Zürneck, 1973); these had their geographic range significantly extended from the very south of Brazil northward along the Brazilian coast (see fig. 1). The remaining four species represent not only new records for Brazil but also the first time these genera are recorded in the country (i.e., Hormathia, Chondrophellia, Actinoscyphia, Amphianthus). All these species were collected in the continental margin and correspond to species typically found in the deep sea of the SWA or North
Atlantic. Similarly, the four species recorded for the SMAR are typically found in deep waters of the Southern Ocean and one of them is also recorded on the coast of Argentina (i.e., Isotealia antarctica), suggesting broad geographic ranges for these species and connectivity across the SMAR, the Southern Ocean and the SWA.

Two of the species recorded in the continental margin of Brazil, Amphianthus lacteus and Hormathia pectinata, suggest connectivity across the subtropical convergence. These two species are widespread, found on both sides of South America, with their type localities off the eastern Pacific in southern Chile and disjunct populations in Argentina (Riemann-Zürneck, 1986). Until now, however, these species had not been recorded north of Rio de La Plata, a proposed biogeographic transition zone due to the collision of the warm Brazilian Current and the colder, mostly sub-Antarctic, Malvinas Current creating the subtropical Atlantic convergence $\left(30^{\circ} \mathrm{S}-36^{\circ} \mathrm{S}\right)$ and the South Atlantic Central Water (SACW), which flows northward beneath the Brazilian Current (Acha et al., 2004). Although the Rio de la Plata acts as a strong barrier for shallow water sea anemones (Zamponi et al., 1998), some species can cross this barrier (e.g., Antholoba achates Drayton in Dana, 1846) as well as other cnidarians (e.g., hydroids, Imazu et al., 2014). Antholoba achates is even more widespread in South America than A. lacteus and $H$. pectinata, being found from Peru to Cabo Frio in Brazil (Riemann-Zürneck, 1986), a distribution that corresponds to the temperate South America realm of Spalding et al. (2007) for shallow water species (0-200 m). Similar to An. achates, A. lacteus is also a brooding species (fig. 13E) without dispersal of early larval stages. Other species with populations on both sides of South America also brood their young (e.g., Paractis laevis: Carlgren, 1899; Bunodactis octoradiata: Carlgren, 1899), which might suggest that though pelagic larvae are usually considered the means of dispersal over long distances (Riemann-Zürneck, 1976), drifting and rafting of postmetamorphic juveniles- 


\section{TABLE 11}

Deep-sea anemones from the Southwestern Atlantic off the coast of Brazil Families and species within families are organized alphabetically.

\begin{tabular}{|c|c|c|c|c|}
\hline Taxon & Family & Locality & Depth & Reference \\
\hline $\begin{array}{l}\text { Actinoscyphia saginata } \\
\text { Verrill, } 1882\end{array}$ & Actinoscyphiidae & $\begin{array}{l}\text { Espírito Santo Basin off Espírito } \\
\text { Santo, Brazil }\end{array}$ & $1402-1694 \mathrm{~m}$ & This study \\
\hline $\begin{array}{l}\text { Amphianthus lacteus } \\
\text { (McMurrich, 1893) }\end{array}$ & Amphianthidae & $\begin{array}{l}\text { Santos Basin off the coast of São } \\
\text { Paulo, Brazil }\end{array}$ & $398-821 \mathrm{~m}$ & This study \\
\hline $\begin{array}{l}\text { Isoscolanthus iemanjae } \\
\text { Brandão et al., } 2019\end{array}$ & Edwardsiidae & $\begin{array}{l}\text { Campos Basin off Rio de Janeiro, } \\
\text { Brazil }\end{array}$ & $202-902 \mathrm{~m}$ & Brandão et al., 2019 \\
\hline $\begin{array}{l}\text { Isoscolanthus janainae } \\
\text { Brandão et al., } 2019\end{array}$ & Edwardsiidae & $\begin{array}{l}\text { Campos Basin off Rio de Janeiro, } \\
\text { Brazil }\end{array}$ & $295-300 \mathrm{~m}$ & Brandão et al., 2019 \\
\hline $\begin{array}{l}\text { Actinauge longicornis } \\
\text { (Verrill, 1882) }\end{array}$ & Hormathiidae & $\begin{array}{l}\text { Pelotas Basin, off Rio Grande do Sul, } \\
\text { Brazil }\end{array}$ & $270-1000 \mathrm{~m}$ & $\begin{array}{l}\text { Riemann-Zürneck, } \\
1973,1986\end{array}$ \\
\hline $\begin{array}{l}\text { Chondrophellia coronata } \\
\text { (Verrill 1883) }\end{array}$ & Hormathiidae & $\begin{array}{l}\text { Campos Basin off Rio de Janeiro, } \\
\text { Brazil }\end{array}$ & $1077-1620 \mathrm{~m}$ & This study \\
\hline $\begin{array}{l}\text { Hormathia pectinata } \\
\text { (Hertwig, 1882) }\end{array}$ & Hormathiidae & $\begin{array}{l}\text { Pelotas Basin off Rio Grande do Sul, } \\
\text { Brazil }\end{array}$ & $526 \mathrm{~m}$ & This study \\
\hline $\begin{array}{l}\text { Monactis vestita } \\
\text { (Gravier, 1918) }\end{array}$ & Hormathiidae & $\begin{array}{l}\text { Potiguar Basin off Rio Grande do } \\
\text { Norte, Brazil }\end{array}$ & $375-2057 \mathrm{~m}$ & Melo et al., 2020 \\
\hline $\begin{array}{l}\text { Paraphelliactis labiata } \\
\text { Melo et al., } 2020\end{array}$ & Hormathiidae & $\begin{array}{l}\text { Potiguar Basin off Rio Grande do } \\
\text { Norte, Brazil }\end{array}$ & $1964-2057 \mathrm{~m}$ & Melo et al., 2020 \\
\hline $\begin{array}{l}\text { Phelliactis capricornis } \\
\text { Riemann-Zürneck, } 1973\end{array}$ & Hormathiidae & $\begin{array}{l}\text { Santos Basin off São Paulo and } \\
\text { Espírito Santos Basin, off Espírito } \\
\text { Santo, Brazil }\end{array}$ & $394-1200 \mathrm{~m}$ & $\begin{array}{l}\text { Riemann-Zürneck, } \\
\text { 1973, 1986, this } \\
\text { study }\end{array}$ \\
\hline $\begin{array}{l}\text { (?) }{ }^{1} \text { Phelliactis lophohelia } \\
\text { Riemann-Zürneck, } 1973\end{array}$ & Hormathiidae & Between $22^{\circ} \mathrm{S}$ and $38 \mathrm{~S}$ & $800 \mathrm{~m}$ & $\begin{array}{l}\text { Riemann-Zürneck, } \\
\text { 1973, } 1986\end{array}$ \\
\hline $\begin{array}{l}\text { Phelliactis pelophila } \\
\text { Riemann-Zürneck, } 1973\end{array}$ & Hormathiidae & $\begin{array}{l}\text { Espírito Santos Basin, Campos Basin } \\
\text { off Rio de Janeiro and Pelotas Basin } \\
\text { off Rio Grande do Sul, Brazil }\end{array}$ & $526-1000 \mathrm{~m}$ & $\begin{array}{l}\text { Riemann-Zürneck, } \\
\text { 1973, 1986, this } \\
\text { study }\end{array}$ \\
\hline $\begin{array}{l}\text { Phelliactis robusta } \\
\text { Carlgren, } 1928 \mathrm{a}\end{array}$ & Hormathiidae & $\begin{array}{l}\text { Potiguar Basin off Rio Grande do } \\
\text { Norte, Brazil }\end{array}$ & $2025-2057 \mathrm{~m}$ & Melo et al., 2020 \\
\hline Phelliactis sp. & Hormathiidae & $\begin{array}{l}\text { Potiguar Basin off Rio Grande do } \\
\text { Norte, Brazil }\end{array}$ & $1896-1931 \mathrm{~m}$ & Melo et al., 2020 \\
\hline
\end{tabular}

${ }^{1}$ (?) Phelliactis lophohelia was collected between $22^{\circ} \mathrm{S}$ and $38^{\circ} \mathrm{S}$, which corresponds to either the coast of Brazil or Argentina (see Riemann-Zürneck, 1973).

which is quite common among sessile cnidarians in circumantarctic waters (Riemann-Zürneck, 1986)-might also be an effective dispersal mechanism. In this sense, the distribution of $A$. lacteus and An. achates shows that some barriers, such as the subtropical convergence, can be semipermeable and affect taxa differently according to specific biological traits (Luiz et al., 2012). Oceanographic currents in the SWA seem to influence species composition among hydroids functioning either as a barrier to larval survival and colonization or as a means for species dispersal (Miranda et al., 2015).

Because so few deep-sea anemones have been recorded off Brazil, it is possible that more species are able to cross the subtropical convergence or are brought via offshore currents such as the northward flow of the Antarctic Intermediate Water (AAIW) (Reid, 1989) at depths between 800-1000 $\mathrm{m}$ and the layers beneath it (i.e., Upper 
TABLE 12

List of sea anemone species from Brazil

Families and species within families are organized alphabetically. Deep-sea anemones indicated in bold; ${ }^{*}$ indicates those species Fautin (2016) determined to be nomina nuda.

\begin{tabular}{|c|c|c|}
\hline Taxon & Family & Main references \\
\hline Actinia bermudensis (McMurrich, 1889) & Actiniidae & $\begin{array}{l}\text { Corrêa, 1964, 1973a; Belém and Preslercravo, 1973; } \\
\text { Dube, 1974, 1975; Belém, 1976, 1980; Gomes and } \\
\text { Mayal, 1997; Zamponi et al., } 1998\end{array}$ \\
\hline Actinostella correae (Schlenz and Belém, 1992) & Actiniidae & $\begin{array}{l}\text { Schlenz and Belém, 1992; Zamponi et al., 1998; } \\
\text { Echeverria et al., } 1997\end{array}$ \\
\hline Actinostella flosculifera (Le Sueur, 1817) & Actiniidae & $\begin{array}{l}\text { Corrêa, 1964; Dube, 1974, 1976a; Belém, 1976; } \\
\text { Belém and Preslercravo, 1973; Schlenz and Belém, } \\
\text { 1992; Gomes and Mayal, } 1997\end{array}$ \\
\hline Anemonia sargassensis Hargitt, 1908 & Actiniidae & $\begin{array}{l}\text { Corrêa, 1964; Dube, 1974, 1975; Belém, 1976; Zam- } \\
\text { poni et al., 1998; Pires et al., } 1992\end{array}$ \\
\hline Anthopleura cascaia* & Actiniidae & $\begin{array}{l}\text { Corrêa, 1964; Dube, 1974, 1977; Rosso, 1984; } \\
\text { Gomes and Mayal, 1997; Zamponi et al., } 1998\end{array}$ \\
\hline $\begin{array}{l}\text { Anthopleura krebsi } \\
\text { Duchassaing and Michelotti, } 1860\end{array}$ & Actiniidae & $\begin{array}{l}\text { Belém and Pinto, 1990; Gomes and Mayal, 1997; } \\
\text { Zamponi et al., } 1998\end{array}$ \\
\hline Anthopleura varioarmata Watzl, 1922 & Actiniidae & $\begin{array}{l}\text { Belém and Monteiro, 1980[THIS DATE NOT IN } \\
\text { REFS, IN REFS 1977; Zamponi et al., } 1998\end{array}$ \\
\hline Bunodosoma caissarum Corrêa in Belém, 1987 & Actiniidae & $\begin{array}{l}\text { Corrêa, 1964; Belém, 1987; Traldi and Schlenz, } \\
\text { 1990; Zamponi et al., } 1998\end{array}$ \\
\hline $\begin{array}{l}\text { Bunodosoma cangicum } \\
\text { Belém and Preslercravo, } 1973\end{array}$ & Actiniidae & $\begin{array}{l}\text { Corrêa, 1964; Belém and Preslercravo, 1973; Dube, } \\
\text { 1976b, 1978; Zamponi et al., } 1998\end{array}$ \\
\hline Condylactis gigantea (Weinland, 1860) & Actiniidae & Corrêa, 1973a; Zamponi et al., 1998 \\
\hline Paracondylactis hertwigi (Wassilieff, 1908) & Actiniidae & Corrêa and Schlenz, 1976; Zamponi et al., 1998 \\
\hline Phymactis braziliensis Carlgren, 1939 & Actiniidae & Carlgren, 1939; Fautin, 2016 \\
\hline Phymactis pustulata (Couthouy in Dana, 1846) & Actiniidae & Dana, 1846; Fautin, 2016 \\
\hline Psammanthus caraguaensis ${ }^{\star}$ & Actiniidae & $\begin{array}{l}\text { Rosso, 1984; Gomes and Mayal, 1997; Zamponi et } \\
\text { al., } 1998\end{array}$ \\
\hline Pseudoactinia infecunda (McMurrich, 1893) & Actiniidae & McMurrich, 1893 \\
\hline Actinoscyphia saginata Verrill, 1882 & Actinoscyphiidae & This study \\
\hline Paranthus rapiformis (Le Sueur, 1817) & Actinostolidae+ & Corrêa, 1964; Zamponi et al., 1998; Schlenz, 1983 \\
\hline Paranthus rhodora (Couthouy in Dana, 1846) & Actinostoloidae & Dana, 1846; Fautin, 2016 \\
\hline Aiptasia prima (Stephenson, 1918) & Aiptasiidae & Stephenson, 1918a; Fautin, 2016 \\
\hline Bellactis ilkalyseae Dube, 1983 & Aiptasiidae & $\begin{array}{l}\text { Dube, 1974, 1983; Pires et al., 1992; Zamponi et al., } \\
1998\end{array}$ \\
\hline $\begin{array}{l}\text { Exaiptasia brasiliensis } \\
\text { Grajales and Rodríguez, } 2016\end{array}$ & Aiptasiidae & Grajales and Rodríguez, 2016 \\
\hline Exaiptasia pallida (Agassiz in Verrill, 1864) & Aiptasiidae & $\begin{array}{l}\text { Corrêa, 1964; Pires et al., 1992; Grajales and Rodrí- } \\
\text { guez,, 2014; Echeverría et al., 1997; Zamponi et al., } \\
\text { 1998; }\end{array}$ \\
\hline Alicia mirabilis Johnson, 1861 & Aliciidae & $\begin{array}{l}\text { Corrêa, 1973a; Gomes and Mayal, 1997; Zamponi } \\
\text { et al., } 1998\end{array}$ \\
\hline
\end{tabular}


TABLE 12 continued

\begin{tabular}{|c|c|c|}
\hline Taxon & Family & Main references \\
\hline Alicia uruguayensis Carlgren, 1927 & Aliciidae & Carlgren, 1927; Fautin, 2016 \\
\hline Lebrunia coralligens (Wilson, 1890) & Aliciidae & Corrêa, 1973a; Zamponi et al., 1998 \\
\hline $\begin{array}{l}\text { Lebrunia neglecta } \\
\text { Duchassaing and Michelotti, } 1860\end{array}$ & Aliciidae & $\begin{array}{l}\text { Corrêa, 1973a; Dube, 1981; Gomes and Mayal, } \\
\text { 1997; Zamponi et al., } 1998\end{array}$ \\
\hline Amphianthus lacteus (McMurrich, 1893) & Amphianthidae & This study \\
\hline Telmatactis roseni (Watzl, 1922) & Andvakiidae & Belém and Preslercravo, 1973; Zamponi et al., 1998 \\
\hline Telmatactis rufa (Verrill, 1900) & Andvakiidae & $\begin{array}{l}\text { Belém and Schlenz, 1989; Pires et al., 1992; Ech- } \\
\text { everría et al., 1997; Zamponi et al., } 1998\end{array}$ \\
\hline Actinoporus elegans Duchassaing, 1850 & Capneidae & Corrêa, 1973b; Zamponi et al., 1998 \\
\hline Diadumene leucolena (Verrill, 1866) & Diadumenidae & Gusmão et al., 2018 \\
\hline Diadumene lineata (Verrill, 1869b) & Diadumenidae & $\begin{array}{l}\text { Belém and Monteiro, 1977; Pires, 1987; Zamponi et } \\
\text { al., } 1998\end{array}$ \\
\hline Diadumene manezinha Gusmão et al., 2018 & Diadumenidae & Gusmão et al., 2018 \\
\hline Diadumene paranaensis Beneti et al., 2015 & Diadumenidae & Beneti et al., 2015 \\
\hline Edwardsia migottoi Gusmão et al., 2016 & Edwardsiidae & Gusmão et al., 2016; Brandão et al., 2019 \\
\hline Isoscolanthus janainae Brandão et al., 2019 & Edwardsiidae & Brandão et al., 2019 \\
\hline Isoscolanthus iemanjae Brandão et al., 2019 & Edwardsiidae & Brandão et al., 2019 \\
\hline Nematostella vectensis Stephenson, 1935 & Edwardsiidae & Silva et al., 2010; Brandão et al., 2019 \\
\hline Scolanthus crypticus Brandão et al., 2019 & Edwardsiidae & Brandão et al., 2019 \\
\hline Tricnidactis errans de Oliveira Pires, 1987 & Haliplanellidae & Pires, 1987; Zamponi et al., 1998 \\
\hline Metapeachia schlenzae Gusmão, 2016 & Haloclavidae & Schlenz, 1985; Gusmão, 2016 \\
\hline Homostichanthus duerdeni Carlgren, 1900 & Homostichanthidae & $\begin{array}{l}\text { Corrêa, 1973a; Dube, 1978; Belém and Presler- } \\
\text { cravo, 1973; Belém, 1980; Gomes and Mayal, 1997; } \\
\text { Zamponi et al., } 1998\end{array}$ \\
\hline Actinauge longicornis (Verrill, 1882) & Hormathiidae & Riemann-Zürneck, 1973, 1986 \\
\hline Calliactis androgyna Riemann-Zürneck, 1975 & Hormathiidae & Riemann-Zürneck, 1975a \\
\hline Calliactis reticulata Stephenson, 1918 & Hormathiidae & Stephenson, 1918a \\
\hline Calliactis tricolor (Le Sueur, 1817) & Hormathiidae & $\begin{array}{l}\text { Corrêa, 1964; Belém and Preslercravo, 1973; Dube, } \\
\text { 1974, 1976a; Zamponi et al., } 1998\end{array}$ \\
\hline Chondrophellia coronata (Verrill, 1883) & Hormathiidae & This study \\
\hline Hormathia pectinata (Hertwig, 1882) & Hormathiidae & This study \\
\hline Monactis vestita (Gravier, 1918) & Hormathiidae & Melo et al., 2020 \\
\hline Paraphelliactis labiata Melo et al., 2020 & Hormathiidae & Melo et al., 2020 \\
\hline Phelliactis capricornis Riemann- Zürneck, 1973 & Hormathiidae & Riemann-Zürneck, 1973, 1986, this study \\
\hline $\begin{array}{l}\text { (?) Phelliactis lophohelia } \\
\text { Riemann-Zürneck, } 1973\end{array}$ & Hormathiidae & Riemann-Zürneck, 1973, 1986 \\
\hline Phelliactis pelophila Riemann-Zürneck, 1973 & Hormathiidae & Riemann-Zürneck, 1973, 1986, this study \\
\hline Phelliactis robusta Carlgren, 1928 a & Hormathiidae & Melo et al., 2020 \\
\hline Phelliactis sp. & Hormathiidae & Melo et al., 2020 \\
\hline Phymanthus canous * & Phymanthiidae & Corrêa, 1964; Zamponi et al., 1998 \\
\hline Anthothoe chilensis (Lesson, 1830) & Sagartiidae & Excoffon et al., 1997; Zamponi et al., 1998 \\
\hline
\end{tabular}


TABLE 12 continued

\begin{tabular}{lll}
\hline Taxon & Family & Main references \\
\hline Carcinactis dolosa Riemann-Zürneck, 1975 & Sagartiidae & Riemann-Zurneck, 1975b; Zamponi et al., 1998 \\
Stichodactyla helianthus (Ellis, 1767) & Stichodactylidae & Laborel, 1969; Belém and Preslercravo, 1973 \\
Cystiactis gaudichaudi Milne Edwards, 1857 & Incertae sedis & Milne Edwards, 1857; Fautin, 2016 \\
Paractis sanctaecatherinae (Lesson, 1830) & Incertae sedis & Lesson, 1830; Fautin, 2016 \\
Williamsactis brasiliensis & Incertae sedis & Milne Edwards, 1857; Fautin, 2016 \\
(Tilesius in Milne Edwards, 1857) & & \\
\hline
\end{tabular}

Circumpolar Deep Water, UCDW; Antarctic Bottom Water, AABW), which are critical for local dispersal of heat, salt, and other constituents at their respective depths (Campos et al., 1995). Around Cabo Frio ( $\left.23^{\circ} S\right)$, a region of upwelling off the coast of Rio de Janeiro, from 750-900 $\mathrm{m}$ (A. lacteus was collected at $735 \mathrm{~m}$ ) the influence of the AAIW may be associated with the northern end of a cold and fresh shelf current that originates on the Argentinian shelf (Piola, 1994), derived ultimately from the shelf region of the northern Drake Passage and representing a major conduit for exchange of biota (Campos et al., 1995). The South Atlantic gyre might also be involved in the dispersal of larvae or juveniles between Argentina and Brazil (e.g., Floeter et al., 2008).

The presence of Chondrophellia coronata and Actinoscyphia saginata off the coast of Brazil highlights a possible direct connection between the SWA and the North Atlantic or an indirect one via the Gulf of Mexico where these species are also present (Ammons and Daly, 2008). Though the specific identity of the Actinoscyphia present in the Gulf of Mexico was not given by Ammons and Daly (2008), the description and pictures of the material lead us to believe that it is the same species found in Brazil. The specimens of $C$. coronata in the Gulf of Mexico described by Ammons and Daly (2008), on the other hand, are very different from the species found off the coast of Brazil. In any case, the possibility that both species might be found in the North and South Atlantic illustrates the connec- tion between these regions and exemplifies the extension of North Atlantic provinces into the lower bathyal region proposed by Watling et al. (2013), which extends from the Gulf of Mexico to northeastern Brazil. The extension of the Caribbean province down to the southeastern coast of Brazil was also hypothesized by Ammons and Daly (2008). Our findings support a closer relationship between the fauna of sea anemones from Brazil and the North Atlantic and/or Gulf of Mexico, and they indicate that the Amazon River has been a semipermeable barrier to sea anemones, as might be the case for other organisms (Floeter et al., 2008). No coastal realm was distinguished for the South American coast of Brazil with its very narrow continental shelf and lower endemicity in the pelagic and deep-sea environments (Costello et al., 2017). In addition, Costello et al. (2017) hypothesized that the Caribbean realm extends further southward along the Brazilian coast to Rio de Janeiro.

The species documented here improve our knowledge of deep-sea anemones in the Central South Atlantic, especially between $10^{\circ} \mathrm{S}-50^{\circ} \mathrm{S}$, an area that remains undersampled and understudied in comparison with the North Atlantic and North MAR (NMAR) (Perez et al., 2012). In fact, no anemone species had been recorded from the same area of the SMAR our specimens were collected, highlighting that the region is one of the least-studied areas of the world oceans (OBIS, 2020). Despite the fact that the SMAR is the most prominent feature of the South Atlantic (Perez et al., 2012), much of what is known about 
it derives from large-scale expeditions in the late 19th century (Wüst, 1964) and more recent expeditions to chemosynthetic ecosystems in the northern and southern extremes of the MidAtlantic Ridge as well as adjacent seamount chains (Perez et al., 2012). As a result, only 13 species are known exclusively for SMAR islands: four species from Tristan da Cunha, Nightingale, and the Inaccessible islands (Carlgren, 1941b) and nine species from Santa Helena (Carlgren, 1941a). All of these species are intertidal, except for Phelliactis giganteus and Amphianthus sanctaehelenae, both collected between 360-380 m. The four species studied here were not collected off SMAR islands but adjacent to the SMAR and in much deeper waters $(>1400 \mathrm{~m}$; mostly $>4120$ $\mathrm{m})$. These four species correspond to typical deep-sea anemone fauna and, except for Isotealia antarctica, which is also found off the coast of Argentina, Chile, and Antarctica, have never been recorded for the Central South Atlantic. Our records represent the northernmost collection sites for all four species, including Actinernus mercedae, with two of them found beyond the Southern Ocean for the first time, a rare occurrence in Actiniaria (see Rodríguez et al., 2007). The diversity of sea anemones in the SMAR suggests similarity to the Southern Ocean fauna that has also been found for the island of Tristan da Cunha (Carlgren, 1941b). Though the Southern Ocean has generally been considered a zoogeographic unit of its own (Watling et al., 2013), the northward movement of Antarctic deep waters may serve as a connection between deep waters of the Southern Ocean and those of other deep-sea basins across and below the Antarctic Polar Front (Brandt et al., 2007; Barboza et al., 2011). In addition, our finding of Actinoscyphia saginata and Bolocera kerguelensis outside of high latitudes on the Brazilian coast and SMAR, respectively, suggests that these species have bipolar distributions with an equatorial submergence (Stepanjants et al., 2006).

The relative abundance of the deep-sea anemones has been demonstrated since the very first oceanic expeditions, including the
Challenger in which several species and specimens of the same species were frequently collected at the same station (Hertwig, 1882). Sea anemones are a sessile, long-lived, and striking and frequent faunal element in the deep-sea which makes them suitable for biogeographical and monitoring studies (Riemann-Zürneck, 1986). The main reason for their exclusion is that the identification and classification of sea anemones is not trivial, but rather is fraught with difficulties associated to their morphological simplicity (e.g., scarcity of morphological characters, loss and convergence, phenotypic plasticity), lack of evaluations of homology and phylogenetic value for many characters, among others (Rodríguez et al., 2014). In practice, the delimitation of intraspecific and interspecific variability is hard with taxa distinguished by a mosaic of characters that are inconsistently used to differentiate taxonomic groups (e.g., genera, families, suborders). As a result, certain deep-sea genera may display low variability between species found poles apart (e.g., Actinoscyphia, Halcampoides Danielssen, 1890), whereas others have multiple species in a single ocean basin (e.g., Actinostola, Amphianthus, Phelliactis). The taxonomic impediment is pervasive in deep-sea anemones with the description of any new species or the accuracy of specimen identification inevitably requiring the revision of entire genera or families. This is aggravated by the quality of the old descriptions not always containing current taxonomic relevant characters and often based on a single or few specimens, thus excluding any intraspecific variability.

Our identifications and conclusions hinge on the current state of sea anemone taxonomy and systematics as well as other limitations of the study of deep-sea taxa that are not unique to sea anemones. These limitations include the high proportion of species new to science in the deep sea (Smith et al., 2008; Brandt et al., 2012) and logistical or methodological challenges resulting in the collection of few specimens often not properly preserved for molecular studies (Brandt 
et al., 2012). In addition, the geographic coverage of deep-sea material display sampling bias (McClain and Hardy, 2010) with genetic data often rare for species from deep-sea habitats other than seamounts and hydrothermal vents (McClain and Hardy, 2010; Taylor and Roterman, 2017). Most deep-sea anemone species properly preserved for molecular work have been included in phylogenetic studies with a heavy bias toward certain regions (e.g., Antarctica, North Atlantic) but rarely for studies at the level of populations or closely related species. We recognize the importance of steps toward a more integrative approach that link taxonomic practice and evolutionary biology (e.g., Padial et al., 2010) and shed light on pattern and process (de Queiroz, 2007). Due to logistical restrictions, however, we were unable to use a more integrative approach of combining different types of data and relied solely on the morphological criteria with all its associated flaws (e.g., lack of population-level variation) to identify species. In addition, the morphological criteria may be unable to detect cryptic species, a feature thought to be common in the sea (e.g., Knowlton, 1993, 2000; Carmona et al., 2011), especially along bathymetric gradients in the deep-sea (Glazier and Etter, 2014).

Though generalizations remain tentative due to methodological limitations, our results suggest that sea anemones in the deep sea of the SWA might have high dispersal, compared with shallow water species, leading to broad biogeographic ranges, which has been found for other deep-sea taxa (e.g., Rex and Etter, 2010; Vanreusel et al., 2010). Higher dispersal potential augmented by extended larval development in the deep (McClain and Hardy, 2010) could explain the broad ranges of some of the deep-sea anemones we identified in this study (e.g., Bolocera kerguelensis, Actinoscyphia saginata, Actinernus mercedae). Broad geographic ranges resulting from large dispersal in deep-sea invertebrates may also be associated with the scarcity and patchiness of hard substrate in the deep sea (Baco et al., 2016). However, dispersal distances and connectivity in the deep ocean are not well understood (Baco et al., 2016), high population connectivity has been found for many groups in the deep sea on regional and oceanic scales (Taylor and Roterman, 2017), particularly among abyssal organisms like Actinernus mercedae. On the contrary, broad species ranges could be due to misidentification (Molodtsova et al., 2008), cryptic speciation (Taylor and Roterman, 2017), or a bias toward the discovery and documentation of the wide ranging species first in the deep sea (McClain and Hardy, 2010; Rex and Etter, 2010; Higgs and Attrill, 2015). Until a high-quality geographic data is assembled for deep-sea anemones, the evaluation of the fine-scale patterns of their species ranges remains speculative.

Our study represents an effort to describe benthic invertebrate diversity in the SWA, which represents only $0.06 \%$ of the records below $500 \mathrm{~m}$ in the Ocean Biogeographic Information System (OBIS) database (De Leo et al., 2020). Given the scarcity of collections of deep-sea anemones in Brazil, this study highlights the importance of natural history museum collections as essential repositories of marine biodiversity information, particularly for organisms from hard-to-access areas such as the deep sea. We recognize the importance of taking steps toward a more integrative approach that link taxonomic practice and evolutionary biology and shed light on patterns and processes (de Queiroz, 2007). Thus, the species identified in this study are considered hypothetical, to be revised in light of additional data. This is particularly important as sampling bias, taxonomic impediment, and cryptic diversity have been shown to mask diversity in the deep sea, especially in the absence of molecular material (Brand et al., 2012). In addition, basic ecological information (e.g., population genetic diversity, dispersal capability, and demographic parameters) for deep-sea anemones is still rare and would greatly help to characterize cryptic diversity. Moreover, the literature suggests that deep-sea benthic diversity varies by ocean basin and taxon (McClain and Schlacher, 2015); as a result, increasing survey efforts as well as training new 
taxonomists will likely help resolve questions created by the high proportion of deep-sea species and the need for detailed taxonomic revisions of diverse and widespread genera of deep-sea anemones (e.g., Amphianthus, Phelliactis, Sicyonis). This combined effort will likely generate insights into the connectivity of marine invertebrates in the deep sea of the SWA. In addition to the species recorded in this study, others await description, including a putative new species of Stephanauge representing the first record of this genus in the South Atlantic as well as an undescribed species of Phelliactis (L.C.G., personal obs.).

\section{ACKNOWLEDGMENTS}

We thank Elena Rubiera and Sebastian Bahos for invaluable help gathering data for this study while they were students of the Science Mentoring Research Program (SRMP) at the American Museum of Natural History (AMNH). Debora Pires from the Museu Nacional do Rio de Janeiro (MNRJ) is thanked for assistance during visits to the Actiniaria collection at the MNRJ and loan of the material described in this study. We also thank Lily Berniker (AMNH) for managing the loans. Many thanks to Abby Reft (USNM) for always sharing her expertise on nematocysts. We also acknowledge with gratitude the officers and crew of the R/V Polarstern during the ANDEEP cruise for their valuable assistance. This study was supported by a Science Without Borders Fellowship (PDE-201874/2014-8) from the Conselho Nacional de Desenvolvimento Científico e Tecnológico (CNPq) - Brazil to L.C.G. Partial support was provided by a MCT-CSIC grant (I3P-BPD2001-1) to E.R., and Spanish CICYT project REN20014269-E/ANT. Support for SRMP (AMNH) is provided by Christopher C. Davis, the Shelby Cullom Davis Charitable Fund; the Pinkerton Foundation; the Bezos Family Foundation; the Doris Duke Charitable Foundation; the Solon E. Summerfield Foundation; Inc.; and the Adolph and Ruth Schnurmacher Foundation. The authors also thank Janine Luke for supporting E.R.'s research program and L.C.G.

\section{REFERENCES}

Acha, E.M., H. Mianzan, R.A. Guerrero, M. Favero, and J. Bava. 2004. Marine fronts at the continental shelves of austral South America physical and ecological processes. Journal of Marine Systems 44: 83-105.

Ammons, A.W., and M. Daly. 2008. Distribution, habitat use and ecology of deepwater Anemones (Actiniaria) in the Gulf of Mexico. Deep-sea Research II 55: 2657-2666.

Amsler, C.D., J.B. McClintock, and B.J. Baker. 1999. An Antarctic feeding triangle: defensive interactions between macroalgae, sea urchins, and sea anemones. Marine Ecology Progress Series 183: 105-114.

Andres, A. 1881. Prodromus neapolitanae actiniarum faunae addito generalis actiniarum bibliographiae catalogo. Mitteilungen aus der Zoologischen Station zu Neapel 2: 305-37.

Andres, A. 1883. Le Attinie. Atti dell' Accademia de Lincei 14: 211-673.

Baco, A.R., et al. 2016. A synthesis of genetic connectivity in deep-sea fauna and implications for marine reserve design. Molecular Ecology 25: 3276-3298.

Barboza, C.A.M., R. Bendayan De Moura, A. Monnerat Lanna, O. Oackes, and L.S. Campos, 2011. Echinoderms as clues to Antarctic-South American connectivity. Oecologia Australis 15: 86-110.

Belém, M.J.C. 1976. Estudo sistematico e histologico de quatro especies de Endomyaria (Actiniaria) encontradas no Municipio de Aracruz, ES, Brasil. Master's thesis, Museu Nacional, Universidade Federal do Rio de Janeiro, Rio de Janeiro.

Belém, M.J.C. 1980. Redescrição de Homostichanthus duerdeni Carlgren, 1900 (Anthozoa, Actiniaria) (Contribuições ao conhecimento da fauna de Cnidários do Espírito Santo, Brasil, 2.). Revista Nordestina de Biologia 3: 9-24.

Belém, M. J. C. 1987. Anatomy and biology of Bunodosoma caissarum Correa, 1964 (Cnidaria, Anthozoa, Actiniidae). Anais da Academia Brasileira de Ciências 60: 365-375.

Belém, M.J.C., and D.C. Monteiro. 1977. Contribuições ao conhecimento da fauna de cnidários do Rio de Janeiro. II. Haliplanella luciae (Verrill, 1988) (Actinaria, Acontiaria), uma nova ocorrência no Brasil. Avulsos do Museu Nacional 26: 1-19.

Belém, M.J.D., and J.D. Preslercravo. 1973. Contribuições ao conhecimento da fauna de cnidarios do Espírito Santo, Brasil I-Considerações sobre Actiniaria do Município de Aracruz, ES. Bole- 
tim do Museu de Biologia Prof. Mello Leitao 80: $1-14$.

Belém, M.J.D., and D. Monteiro. 1981. Fauna de cnidários do Rio de Janeiro. III - Anthopleura varioarmata Watzl, 1922 (Actiniaria, Endomyaria), uma nova ocorrência de Actiniidae. Seminários de Biologia Marinha Academia Brasileira de Ciências Rio de Janeiro 193-203.

Belém, M.J.C., and E. Schlenz. 1989. First record of an Isophelliidae (Cnidaria, Actiniaria) in Brazil, with the redescription of Telmatactis rufa (Verrill, 1900) and observations on its asexual reproduction. Anais da Academia Brasileira de Ciências (Rio de Janeiro) 61: 343-353.

Belém, M.J.C., and S.M. Pinto. 1990. Morphological and microanatomical study of Anthopleura krebsi Duchassaing and Michelotti, 1860 (Cnidaria, Anlhozoa, Actiniidae), a new record in Brazil. Anais da Academia Brasileira de Ciências 62: 183-192.

Beneti, J.S., S.N. Stampar, M.M. Maronna, A.C. Morandini, and F.L. Silveira. 2015. A new species of Diadumene (Actiniaria: Diadumenidae) from the subtropical coast of Brazil. Zootaxa 4021 (1): 156-168.

Brandão, R.A., L.C. Gusmão, and P.B. Gomes. 2019. Diversity of Edwardsiidae sea anemones (Cnidaria: Anthozoa: Actiniaria) from Brazil, with the description of a new genus and species. Journal of the Marine Biological Association of the United Kingdom 99 (5): 1-12.

Brandt, A., et al. 2007. The Southern Ocean deep sea: first insights into biodiversity and biogeography. Nature 447: 307-311.

Brandt, A., et al. 2012. Are there widespread peracarid species in the deep sea (Crustacea: Malacostraca)? Polish Polar Research 33: 139-162.

Campos, J.D., J.L. Miller, T.J. Müller, and R.G. Peterson. 1995. Physical oceanography of the Southwest Atlantic Ocean. Oceanography 8: 87-91.

Carlgren, O. 1893. Studien über nordische Aktinien. Kungliga Svenska Vetenskapsakademiens Handlingar 25: 1-148.

Carlgren, O. 1899. Zoantharien. Hamburger Magalhaensische Sammelreise 4: 1-48.

Carlgren, O. 1900. Ostafrikanische Actinien. Gesammelt von Herrn Dr. F. Stuhlmann 1888 und 1889. Mittheilungen aus dem Naturhistorischen Museum 17, 21-144.

Carlgren, O. 1914. On the genus Porponia and related genera, Scottish National Antarctic Expedition. Transactions of the Royal Society of Edimburg 50: 49-71.
Carlgren, O. 1918. Die Mesenterienanordnung der Halcuriiden. Kungliga Fysiografiska Sällskapets Handlingar 29: 1-37.

Carlgren, O. 1921. Actiniaria Part I. Danish IngolfExpedition 5: 1-241.

Carlgren, O. 1925. On the actiniarian family Amphianthidae. Arkiv für Zoologi 17B: 1-6.

Carlgren, O. 1927. Actiniaria and Zoantharia. In $\mathrm{T}$. Odhner (editor), Further Zoological Results of the Swedish Antarctic Expedition 1901-1903: 1-102. Stockholm: P.A. Norstedt and Söner.

Carlgren, O. 1928a. Actiniaria der Deutschen Tiefsee-Expedition. Wissenschaftliche Ergebnisse der Deutschen Tiefsee-Expedition auf dem Dampfer "Valdivia" 18981899, vol. 22: 125-266. Jena: G. Fischer.

Carlgren, O. 1928b. Ceriantharier, Zoantharier och Actiniarier. Meddelelser om Grønland 23 (Suppl.): 253-308.

Carlgren, O. 1932. Die Ceriantharien, Zoantharien und Actiniarien des arktischen Gebietes. In F. Römer, F. Schaudinn, A. Brauer, and W. Arndt (editors), Eine Zusammenstellung der arktischen Tierformen mit besonderer Berücksichtigung des Spitzbergen-Gebietes auf Grund der Ergebnisse der Deutschen Expedition in das Nördliche Eismeer im Jahre 1898: 255-266. Jena: Gustav Fischer.

Carlgren, O. 1934. Ceriantharia, Zoantharia and Actiniaria from the "Michael Sars" North Atlantic Deepsea Expedition 1910. Report on the Scientific Results of the "Michael Sars" North Atlantic DeepSea Expedition 1910, vol. 5: 1-27. Bergen: Trustees of the Bergen Museum.

Carlgren, O. 1936. Some west American sea anemones. Journal of the Washington Academy of Sciences 26: $16-23$.

Carlgren, O. 1938. South African Actiniaria and Zoantharia. Kungliga Svenska Vetenskapsakademiens Handlingar 17: 1-148.

Carlgren, O. 1939. Actiniaria and Zoantharia of the Scottish National Antarctic Expedition, 1902-1904. Transactions of the Royal Society of Edinburgh 49: 791-800.

Carlgren, O. 1941a. The Actiniaria and Zoantharia of St. Helena. Papers from Dr. Th. Mortensen's Pacific Expedition 1914-16. LXX. Videnskabelige Meddelelser fra Dansk Naturhistorisk Forening (Copenhagen) 105: 1-20.

Carlgren, O. 1941b. Corallimorpharia, Actiniaria, and Zoantharia. Results of the Norwegian Scientific Expedition to Tristan da Cunha 1937-1938 1: 1-12. Oslo: Norske Videnskaps-akademi. 
Carlgren, O. 1942. Actiniaria Part II. Danish IngolfExpedition 5: 1-92. Copenhagen: H. Hagerup.

Carlgren, O. 1949. A survey of the Ptychodactiaria, Corallimorpharia and Actiniaria. Kungliga Svenska Vetenskapsakademiens Handlingar 1: 1-121.

Carlgren, O. 1956. Actiniaria from depths exceeding 6000 meters. Galathea Reports 2: 9-16.

Carlgren, O. 1959. Corallimorpharia and Actiniaria with description of a new genus and species from Peru. Reports of the Lund University Chile Expedition 1948-49 38. Arkiv für Zoologi 71: 1-38.

Carlgren, O., and T.A. Stephenson. 1929. Actiniaria. In E.A. Briggs (editor), Australasian Antarctic Expedition 1911-14 under the leadership of Sir Douglas Mawson, O.B.E., D.Sc., B.E., F.R.S. Scientific Reports. Series C. Zoology and Botany: 5-34. Alfred James Kent, Government Printer, Sydney.

Carmona, L., M.A.E. Malaquias, T.M. Gosliner, M. Pola, and J.L. Cervera. 2011. Amphi-Atlantic distributions and cryptic species in Sacoglossan sea slugs. Journal of Molluscan Studies 77: 401-412.

Corrêa, D.D. 1964. Corallimorpharia e Actiniaria do Atlântico oeste tropical. Ph.D. dissertation, Faculdade de Filosofia, Ciências e Letras, Universidade de São Paulo, São Paulo.

Corrêa, D.D. 1973a. Sobre anêmonas-do-mar (Actiniaria) do Brasil. Boletim de Zoologia e Biologia Marinha, Nova Série (São Paulo) 30: 457-468.

Corrêa, D.D. 1973b. On the sea-anemone Actinoporus elegans Duchassaing. Publications of the Seto Marine Biological Laboratory 20: 157-164.

Corrêa, D.D., and E. Schlenz. 1976. On the Sea Anemone Paracondylactis hertwigi (Wassilief, 1908). Boletim de Zoologia, Universidade de São Paulo 1: 69-80.

Costello, M.J., et al. 2010. A census of marine biodiversity knowledge, resources, and future challenges. PLoS ONE 5 (8): e12110.

Costello, M.J, et al. 2017. Marine biogeographic realms and species endemicity. Nature Communications 8 (1):1057.

Dana, J.D. 1846. Zoophytes. Volume VII of the United States Exploring Expedition. During the Years 1838, $1839,1840,1841,1842$. Under the command of Charles Wilkes, U.S.N. Philadelphia: Lea and Blanchard.

Danielssen, D.C. 1890. Actinida. Den Norske Nordhavs-Expedition 1876-1878. Zoologi. Christiania: Grøndahl and Søn.

Dayton, P.K., G.A. Robilliard, R.T. Paine, and L.B. Dayton. 1974. Biological accommodation in the benthic community at McMurdo Sound, Antarctica. Ecological Monographs 44: 105-128.

De Leo, F.C., A.F. Bernardino, and P.Y.G. Sumida. 2020. Continental slope and submarine canyons: benthic biodiversity and human impacts. In P.Y.G. Sumida, F.C. De Leo, and A.F. Bernardino (editors), Brazilian deep-sea biodiversity: 37-72. Cham, Switzerland: Springer.

Doumenc, D.A. 1975. Actinies bathyales et abyssales de locéan Atlantique nord familles des Hormathiidae (genres Paracalliactis et Phelliactis) et des Actinostolidae (genres Actinoscyphia et Sicyonis). Bulletin du Muséum National d'Histoire Naturelle (Paris) 197: 157-204.

Doumenc, D.A., and M. Van-Praët. 1988. Actinies abyssales d'un site hydrothermal du Pacifique oriental. Oceanologica Acta, Special 8-Biologie et icologie des sources hydrothermales: 61-68.

Dube, V.M.C. 1974. Anêmonas-do-mar (Ordem Actiniaria) do Estado da Bahia. Master's thesis, Departamento de Zoologia, Universidade de São Paulo, São Paulo.

Dube, V.M.C. 1975. Contribuição ao estudo das anêmonas-do-mar do estado da Bahia. 1. Actinia bermudensis McMurrich, 1889 e Anemonia sargassensis Hargitt, 1908. Natura 1: 104-110.

Dube, V.M.C. 1976a. Contribuição ao estudo das anêmonas-do-mar do Estado da Bahia. 2. Phyllactis praetexta (Dana, 1846) e Calliactis tricolor (Lesueur, 1817). Natura 2: 101-110.

Dube, V.M.C. 1976b. Contribuição ao estudo das anêmonas-do-mar do Estado da Bahia. 3. Bunodosoma cangicum Corrêa, 1964. Boletim do Instituto de Biologia da Bahia 15: 27-30.

Dube, V.M.C. 1977. Contribuição ao estudo das anêmonas-do-mar do Estado da Bahia. 4. Anthopleura cascaia Correa, 1964. Natura 77: 43-48.

Dube, V.M.C. 1978. Sobre anêmonas-do-mar (Ordem Actiniaria) do Estado da Bahia. Atas da Sociedade de Biologia do Rio de Janeiro 19: 31-32.

Dube, V.M.C. 1981. Uma anêmona-do-mar, Lebrunia danae (Duchassaing and Michelotti, 1860). Atas da Sociedade de Biologia do Rio de Janeiro 22: 3-4.

Dube, V.M.C. 1983. Contribuição ao estudo das anêmonas-do-mar do estado da Bahia. 5, Bellactis ilkaliseae gen. n., sp. n. Natura 5: 82-93.

Duchassaing, P. 1850. Animaux radiaires des Antilles. Paris: Plon Frères.

Duchassaing de Fonbressin, P., and G. Michelotti. 1860. Mémoire sur les coralliaires des Antilles. Turin: Imprimerie Royale.

Duncan, P.M. 1873. A description of the Madreporaria dredged up during the Expeditions of H.M.S. 'Por- 
cupine' in 1869 and 1870. Transactions of the Zoological Society of London 8: 303-344.

Dunn, D.F. 1983. Some Antarctic and sub-Antarctic sea anemones (Coelenterata: Ptychodactiaria and Actiniaria). Antarctic Research Series 39: 1-67.

Dunn, D.F., and G.L. Bakus. 1977. Redescription and ecology of Liponema brevicornis (McMurrich, 1893), with definition of the family Liponematidae (Coelenterata, Actiniaria). Astarte 10: 77-85.

Eash-Loucks, W.E., and D.G. Fautin. 2012. Taxonomy and distribution of sea anemones (Cnidaria: Actiniaria and Corallimorpharia) from deep water of the northeastern Pacific. Zootaxa 3375: 1-80.

Echeverría, C.A., D.O. Pires, M.S. Medeiros, and C.B. Castro. 1997. Cnidarians of the Atol das Rocas. Proceedings of the 8th International Coral Reef Symposium, 1996, Panama 1: 443-446.

Ellis, J. 1767. An account of the Actinia sociata, or clustered animal-flower, lately found on the sea-coasts of the new-ceded islands. Philosophical Transactions of the Royal Society of London 57: 428-437.

Excoffon, A.C., M.J.C. Belém, M.O. Zamponi, and E. Schlenz. 1997. The validity of Anthothoe chilensis (Actiniaria, Sagartiidae) and its distribution in the Southern Hemisphere. Iheringia, Ser. Zool. 82: 107-118.

Fabricius, O. 1780. Fauna groenlandica. Hafniae [Copenhagen]: Ioannis Gottlob Rothe.

Fautin, D.G. 1984. More Antarctic and subantarctic sea anemones (Coelenterata: Corallimorpharia and Actiniaria). Antarctic Research Series 41: 1-42.

Fautin, D.G. 1988. The importance of nematocysts to actiniarian taxonomy. In D.A. Hessinger and H.M. Lenhoff (editors), The biology of nematocysts: 487500. New York: Academic Press.

Fautin, D.G. 2016. Catalog to families, genera, and species of orders Actiniaria and Corallimorpharia (Cnidaria: Anthozoa). Zootaxa 4145: 1-449.

Fautin, D.G., and J.C. den Hartog. 2003. An unusual anemone from the slope depths of the tropical west Pacific: range extension and redescription of Isactinernus quadrilobatus Carlgren, 1918 (Cnidaria: Actiniaria: Actinernidae). Zoologische Verhandelingen Leiden 345: 103-116.

Floeter, S.R., et al. 2008. Atlantic reef fish biogeography and evolution. Journal of Biogeography 35: 22-47.

Gabe, M. 1968. Technique histologique. Paris: Massou et Cie.

Glazier, A.E., and R.J. Etter. 2014. Cryptic speciation along a bathymetric gradient. Biological Journal of the Linnean Society 113: 897-913.
Gomes, P.B., and E.M. Mayal. 1997. Levantamento preliminar das anêmonas-do-mar (Cnidaria: Actiniaria) da costa de Pernambuco, Brasil. Biociências 5: 45-52.

Gosse, P.H. 1858. Characters and descriptions of some new British sea-anemones. Annals and Magazine of Natural History 3, 2: 192-196.

Gosse, P.H. 1859. Characters and descriptions of some new British sea-anemones. Annals and Magazine of Natural History 3: 46-50.

Gosse, P.H. 1860. A history of the British sea-anemones and corals. London: Van Voorst.

Grajales, A., and E. Rodríguez. 2014. Morphological revision of the genus Aiptasia and the family Aiptasiidae (Cnidaria, Actiniaria, Metridioidea). Zootaxa 3826: 55-100.

Grajales, A., and E. Rodríguez. 2016. Elucidating the evolutionary relationships of the Aiptasiidae, a widespread cnidarian-dinoflagellate model system (Cnidaria: Anthozoa: Actiniaria: Metridioidea). Molecular Phylogenetics and Evolution 94: 252-263.

Gravier, C. 1918. Note préliminaire sur les hexactiniaires recueillis au cours des croisières de la Princesse-Alice et del'Hirondelle de 1888 à 1913 inclusivement. Bulletin de l'Institut Océanographique (Monaco): 1-24.

Gusmão, L.C. 2016. Metapeachia schlenzae sp. nov. (Cnidaria: Actiniaria: Haloclavidae), a new burrowing sea anemone from Brazil, with a discussion of the genus Metapeachia. Zootaxa 4072: 373-383.

Gusmão, L.C., and Daly, M. 2010. Evolution of sea anemones (Cnidaria: Actiniaria: Hormathiidae) symbiotic with hermit crabs. Molecular Phylogenetics and Evolution 56: 868-877.

Gusmão, L.C., R.A. Brandão, and M. Daly. 2016. Edwardsia migottoi sp. nov., the first sea anemone species of Edwardsia de Quatrefages 1842 (Anthozoa: Actiniaria: Edwardsiidae) from the southwestern Atlantic. Marine Biodiversity 48: 1313-1323.

Gusmão, L.C., A. Grajales, and E. Rodríguez. 2018. Sea anemones through $\mathrm{X}$-rays: visualization of two species of Diadumene (Cnidaria, Actiniaria) using micro-CT. American Museum Novitates 3907: 1-45.

Gusmão, L.C., L. Berniker, V. Van Deusen, O. Harris, and E. Rodríguez. 2019a. Halcampulactidae (Actiniaria, Actinostoloidea), a new family of burrowing sea anemones with external brooding from Antarctica. Polar Biology 42: 1271-1286.

Gusmão, L.C., E. Rodríguez, M. Daly. 2019b. Description of Calliactis tigris sp. nov.: reconciling taxon- 
omy and phylogeny in hermit-crab symbiotic anemones (Cnidaria: Actiniaria: Hormathiidae). Organisms Diversity and Evolution 19: 567-583.

Haddon, A.C. 1888. On two species of Actiniae from the Mergui Archipelago, collected for the trustees of the Indian Museum, Calcutta, by Dr. John Anderson, F.R.S., Superintendent of the Museum. Journal of the Linnean Society of London (Zoology) 21: 247-255.

Haddon, A.C. 1889. A revision of the British Actiniae. Part I. Scientific Transactions of the Royal Dublin Society 4: $297-361$.

Hargitt, C.W. 1908. Notes on a few coelenterates of Woods Hole. Biological Bulletin 14: 95-120.

Häusserman, V., and G. Försterra. 2005. Distribution patterns of Chilean shallow-water sea anemones (Cnidaria: Anthozoa: Actiniaria, Corallimorpharia), with a discussion of the taxonomic and zoogeographic relationships between the actinofauna of the South East Pacific, the South West Atlantic and the Antarctic. Scientia Marina 69: 91-102.

Hertwig, R. 1882. Report on the Actiniaria dredged by H.M.S. Challenger during the years 1873-1876. Report on the scientific results of the voyage of H.M.S. Challenger during the years 1873-76 (Zoology) 6 (1): 1-136. London: Printed for H.M.S.O.

Hertwig, R. 1888. Report on the Actiniaria dredged by H.M.S. Challenger during the years 1873-1876 [Supplement]. Report on the scientific results of the voyage of H.M.S. Challenger during the years 187376 (Zoology) 26: 1-56. London: Printed for H.M.S.O.

Higgs, N.D., and M.J. Attrill. 2015. Biases in biodiversity: wide-ranging species are discovered first in the deep sea. Frontiers in Marine Science 2: 1-8.

Imazu, M.A., E. Ale, G.N. Genzano, and A.C. Marques. 2014. A comparative study of populations of Ectopleura crocea and Ectopleura ralphi (Hydrozoa, Tubulariidae) from the southwestern Atlantic Ocean. Zootaxa 3753: 421-439.

Izumi, T., T. Fujii, K. Yanagi, T. Higashiji, and T. Fujita. 2019. Redescription of Synactinernus flavus after a century and description of Synactinernus churaumi sp. nov. (Cnidaria, Anthozoa, Actiniaria). Zoological Science 36 (6): 528-538.

Johnson, J.Y. 1861. Notes on the sea-anemones of Madeira, with descriptions of new species. Proceedings of the Zoological Society of London 1861: 298-306.

Johnston, G. 1832. Illustrations in British zoology. Magazine of Natural History 5: 163-164.
Knowlton, N. 1993. Sibling species in the sea. Annual Review of Ecology and Systematics 24: 189-216.

Knowlton, N. 2000. Molecular genetic analyses of species boundaries in the sea. Hydrobiologia 420: 73-90.

Koch, G.V. 1878. Mittheilungen über Coelenteraten. Zur Phylogenie der Antipatharia. Morphologisches Jahrbuch 4: 74- 86.

Laborel, J. 1969. Les peuplements de madréporaires des côtes tropicales du Brésil. Annales de l'Université d'Abidjan. Serie E. Ecologie 2(3): 1-261.

Laird, M.C., and C.L. Griffiths. 2016. Additions to the South African sea anemone (Cnidaria, Actiniaria) fauna, with expanded distributional ranges for known species. Africa Invertebrates 57: 15-37.

Lesson, R.P. 1830. Description des animaux de la famille des actiniées. Voyage autour du monde, exécuté par ordre du Roi, sur la Corvette de La Majesté, La Coquille, pendant les années 1822, 1823, 1824, et 1825 , sous le ministère et conformément aux instructions de S.E.M. de Marquis de Clermont-Tonnerre, ministre de la marine. Paris: Arthus Bertrand.

Le Sueur, C.A. 1817. Observations on several species of the genus Actinia; illustrated by figures. Journal of the Academy of Sciences of Philadelphia 1: 149-154.

Levin, L.A., and A.J. Gooday. 2003. The deep Atlantic Ocean. In P.A. Tyler (editor), Ecosystems of the world 28, ecosystems of the deep sea: 111-178. Amsterdam: Elsevier.

Li, Y., and K. Xu. 2016. Paraphelliactis tangi n. sp. and Phelliactis yapensis n. sp., two new deep-sea species of Hormathiidae (Cnidaria: Anthozoa: Actiniaria) from a seamount in the tropical Western Pacific. Zootaxa 4072: 358-372.

Luiz, O.J., et al. 2012. Ecological traits influencing range expansion across large oceanic dispersal barriers: insights from tropical Atlantic reef fishes. Proceedings of the Royal Society B 279: 1033-1040.

McClain, C.R., and S.M. Hardy. 2010. The dynamics of biogeographic ranges in the deep sea. Proceedings of the Royal Society B 277: 3533-3546.

Mcclain, C.R., and T.A. Schlacher. 2015. On some hypotheses of diversity of animal life at great depths on the sea floor. Marine Ecology 36: 849-872.

McMurrich, J.P. 1889. A contribution to the actinology of the Bermudas. Proceedings of the Academy of Natural Sciences of Philadelphia 1889: 102-126.

McMurrich, J.P. 1893. Report of the Actiniae collected by the United States Fish Commission Steamer Albatross during the winter of 1887-1888. Proceedings of the United States National Museum 16: 119-216. 
McMurrich, J.P. 1893. Report on the Actiniæ collected by the United States Fish Commission Steamer Albatross during the winter of 1887-1888. Proceedings of the United States National Museum 16: 119-216.

McMurrich, J.P. 1904. The Actiniae of the Plate collection. Zoologische Jahrbücher 6: 215-306.

Melo, Y.A., A.K.G. Targino, and P.B. Gomes. 2020. New records of family Hormathiidae (Cnidaria: Actiniaria) from Brazilian coast with description of Paraphelliactis labiata n. sp. Zootaxa 4766: 557-574.

Milne Edwards, H. 1857. Histoire naturelle des coralliaires ou polypes proprement dits, vol. 1. Paris: Librairie Encyclopédique de Roret.

Miloslavich, P., et al. 2011. Marine biodiversity on the Atlantic and Pacific coasts of South America: knowledge and gaps. PLoS One 6:e14631.

Miranda, T.P., G.N. Genzano, and A.C. Marques. 2015. Areas of endemism in the southwestern Atlantic Ocean based on the distribution of benthic hydroids (Cnidaria: Hydrozoa). Zootaxa 4033: 484-506.

Molodtsova, T.N., N.P. Sanamyan, and N.B. Keller. 2008. Anthozoa from the northern Mid-Atlantic Ridge and Charlie-Gibbs Fracture Zone. Marine Biology Research 4: 112-130

Müller, O.F. 1776. Zoologiæ danicæ prodromus, seu animalium daniæ et norvegiæ indigenarum characteres, nomina, et synonyma imprimis popularium. Hafniæ [Copenhagen]: Hallageriis.

OBIS. 2020. Ocean Biogeographic Information System. Intergovernmental oceanographic commission of UNESCO. Internet resource (www.iobis.org), accessed May 1, 2020.

Padial, J.M., A. Miralles, A., I. De la Riva, and M. Vences. 2010. The integrative future of taxonomy. Frontiers in Zoology 7: 16.

Pax, F. 1909. Die Aktinien der ostafrikanischen Inseln. In A. Voeltzkow (editor), Reise in Ostafrika in den Jahren 1903-1905: 399-418. Stuttgart: E. Schweizerbart'sche Verlagsbuchhandlung.

Pax, F. 1922. Diagnosen neuer Actiniarien aus der Ausbeute der Deutschen (1901-1903) und der Französischen (1908-1910) Südpolar-Expedition. Zoologischer Anzeiger 54: 75-93.

Perez, J.A.A., et al. 2012. Patterns of life on the southern Mid-Atlantic Ridge: Compiling what is known and addressing future research. Oceanography 25 (4): 16-31.

Piola, A.R. 1994. The shelf/slope front off Patagonia. In E. Campos (editor), Report of the southwestern Atlantic physical oceanography workshop. São Paulo: University of São Paulo.
Pires, D.O. 1987. Tricnidactis errans, n. gen., n. sp. (Cnidaria, Actiniaria, Haliplanellidae) from Guanabara Bay, Rio de Janeiro, Brazil. Revista Brasileira de Biologia 48 (3): 507-516.

Pires, D.O., C.B Castro, A.E. Migotto, and A.C. Marques. 1992. Cnidários bentônicos do Arquipélago de Fernando de Noronha, Brasil. Boletim do Museu Nacional 354: 1-21.

Prates, A.P., L. Henrique de Lima, A. Chatwin. 2007. Coastal and marine conservation priorities in Brazil. In A. Chatwin (editor), Priorities for coastal and marine conservation in South America: 15-23. Arlington: Nature Conservancy.

Presnell, J.K., and M.P. Schreibman. 1997. Humason's animal tissue techniques. Baltimore: Johns Hopkins University Press.

Queiroz, K. de. 2007. Species concepts and species delimitation. Systematic Biology 56: 879-886.

Rafinesque, C.S. 1815. Analyse de la nature ou Tableau de l'univers et des corps organisés. Palerme: Aux depens de l'auteur.

Reid, J.L. 1989. On the total geostrophic circulation of the South Atlantic Ocean: flow patterns, tracers and transports. Progress in Oceanography 23: 149-244.

Rex, M.A., and R.J. Etter. 2010. Deep-sea biodiversity: pattern and scale. Harvard University Press.

Riemann-Zürneck, K. 1973. Actiniaria des Südwestatlantik I. Hormathiidae. Helgoländer Wissenschaftliche Meeresuntersuchungen 25: 273-325.

Riemann-Zürneck, K. 1975a. Actiniaria des Südwestatlantik III. Calliactis androgyna sp. n. (Hormathiidae). Veröffentlichungen des Institutes für Meeresforschung Bremerhaven 15: 387-395.

Riemann-Zürneck, K. 1975b. Actiniaria des Südwestatlantik II. Sagartiidae und Metridiidae. Helgoländer Wissenschaftliche Meeresuntersuchungen 27: 70-95.

Riemann-Zürneck, K. 1976. A new type of larval development in the Actiniaria: giant larvae. In G.O. Mackie (editor), Morphological and ecological aspects of larval development in Actinostola spetsbergensis: 355-364. New York: Plenum Press.

Riemann-Zürneck, K. 1978. Tiefsee-Aktinien der Familie Actinoscyphiidae aus dem Nordatlantik (Actiniaria, Mesomyaria). Zoologica Scripta 7: 145-153.

Riemann-Zürneck, K. 1979. Two disc-shaped deep sea Anthozoa from the Gulf of Biscay, with a survey of adaptation types in the Actiniaria. Zoomorphologie 93: $227-243$.

Riemann-Zürneck, K. 1980. Actiniaria des Südwestatlantik. V. Bolocera, Isotealia, Isosicyonis (Actiniidae). 
Mitteilungen aus dem Hamburgischen Zoologischen Museum und Institut 77: 19-33.

Riemann-Zürneck, K. 1986. Zur Biogeographie des Südwestatlantik mit besonderer Berücksichtigung der Seeanemonen (Coelenterata: Actiniaria). Helgoländer Wissenschaftliche Meeresuntersuchungen 40: 91-149.

Riemann-Zürneck, K. 1994. Taxonomy and ecological aspects of the subarctic sea anemones Hormathia digitata, Hormathia nodosa and Allantactis parasitica (Coelenterata, Actiniaria). Ophellia 39 (3): 197-224.

Rodríguez, E., and P.J. López-González. 2001. A new species of Hormathia (Actiniaria, Hormathidae) from the eastern Weddell Sea, Antarctica. Helgoland Marine Research 55: 116-123.

Rodríguez, E., and P.J. López-González. 2013. New records of Antarctic and sub-Antarctic sea anemones (Cnidaria, Anthozoa, Actiniaria and Corallimorpharia) from the Weddell Sea, Antarctic Peninsula, and Scotia Arc. Zootaxa 3624: 1-100.

Rodríguez, E., P.J. López-González, and J.M. Gili. 2007. Biogeography of Antarctic sea anemones (Anthozoa, Actiniaria): what do they tell us about the origin of the Antarctic benthic fauna. Deep Sea Research Part 2. Topical Studies in Oceanography 54: 1876-1904.

Rodríguez, E., C.N. Castorani, and M. Daly. 2008. Morphological phylogeny of the family Actinostolidae (Anthozoa: Actiniaria) with description of a new genus and species of hydrothermal vent sea anemone redefining the family Actinoscyphiidae. Invertebrate Systematics 22: 439-452.

Rodríguez, E., M. Barbeitos, M. Daly, L.C. Gusmão, and V. Häussermann. 2012. Toward a natural classification: phylogeny of acontiate sea anemones (Cnidaria, Anthozoa, Actiniaria). Cladistics 28: 375-392.

Rodríguez, E., et al. 2014. Hidden among sea anemones: first comprehensive phylogenetic reconstruction of the order Actiniaria (Cnidaria: Anthozoa: Hexacorallia) reveals a novel group of hexacorals. PLoS ONE 9: 1-15.

Rosso, S. 1984. Biologia de Psammanthus caraguaensis n. gen. n. sp. (Cnidaria - Actiniidae). Master's thesis, Departamento de Zoologia, Universidade de São Paulo, São Paulo.

Roule, L. 1909. Hexactinides. Expedition Antarctique Française (1903-1905): 1-19. Paris: Masson.

Sanamyan, N.P., and K.E. Sanamyan. 2007. Deep-water Actiniaria from East Pacific hydrothermal vents and cold seeps. Invertebrate Zoology 4: 83-102.

Sanamyan, N.P., K.E. Sanamyan, and K.R. Tabachnick. 2012. The first species of Actiniaria, Spongiactis japonica gen. n., sp. n. (Cnidaria: Anthozoa), an obligate symbiont of a glass sponge. Invertebrate Zoology 9: 127-141.

Sanamyan, N.P., K.E. Sanamyan, and L. Lundsten. 2015. Two new deepwater sea anemones (Cnidaria: Anthozoa: Actiniaria) Sicyonis heliodiscus sp. n. (Actinostolidae) and Hormathia pacifica sp. n. (Hormathiidae) from Pacific. Invertebrate Zoology 12: 131-149.

Schlenz, E. 1983. Anemonas (Cnidaria, Actiniaria) do Brasil. Anais da Academia Brasileira de Ciências do Rio de Janeiro, 55 (3): 330-331.

Schlenz, E. 1985. Primeira ocorrência de uma anêmona-do-mar da Família Haloclavidae no Brasil. XII Congresso Brasileiro de Zoologia. Campinas: Sociedade Brasileira de Zoologia.

Schlenz, E., and M.J.D. Belém. 1992. Phyllactis correae n. sp. (Cnidaria, Actiniaria, Actiniidae) from Atol das Rocas, Brazil, with notes on Phyllactis flosculifera (Lesueur, 1817). Boletim de Zoologia (São Paulo) 12: 91-117.

Silva, J.F., C.A. Lima, C.D. Perez, and P.B. Gomes. 2010. First record of the sea anemone Nematostella vectensis (Actiniaria: Edwardsiidae) in southern hemisphere waters. Zootaxa 2343: 66-68.

Simon, J.A. 1892. Ein Beitrag zur Anatomie und Systematik der Hexactinien. München: Val. Hvfling.

Smith, C.R., F. C. de Leo, A.F. Bernardino, A.K. Sweetman, and P.M. Arbizu. 2008. Abyssal food limitation, ecosystem structure and climate change. Trends in Ecology and Evolution 23: 518-528.

Soares, M.O., et al. 2016. Brazilian marine animal forests: A new world to discover in the southwestern Atlantic. In S. Rossi (editor), Marine animal forests: 1-38. Cham, Switzerland: Springer.

Spalding, M.D., et al. 2007. Marine ecoregions of the world: bioregionalization of coastal and shelf areas. Bioscience 57: 573-583.

Stepanjants, S.D., G. Cortese, S.B. Kruglikova, and K.R. Bjørklund. 2006. A review of bipolarity concepts: History and examples from Radiolaria and Medusozoa (Cnidaria), Marine Biology Research 2: 200-241.

Stephenson, T.A. 1918a. Coelenterata. Part I.-Actiniaria. Natural History Reports on British Antarctic ("Terra Nova") Expedition 1910 5: 1-68.

Stephenson, T.A. 1918b. On certain Actiniaria collected off Ireland by the Irish Fisheries Department, during the years of 1899-1913. Proceedings of the Royal Irish Academy 34B: 106-164.

Stephenson, T.A. 1920. On the classification of Actiniaria. Part I.-Forms with acontia and forms with a 
mesogloeal sphincter. Quarterly Journal of Microscopical Science 64: 425-574.

Stephenson, T.A. 1922. On the classification of Actiniaria. Part III.-Definitions connected with the forms dealt with in Part II. Quarterly Journal of Microscopical Science 66: 247-319.

Stephenson, T.A. 1935. The British sea anemones. Vol. 2. London: Ray Society.

Studer, T. 1879. Zweite Abtheilung der Anthozoa polyactinia, welche während der Reise S.M.S. Corvette Gazelle um die Erde gesammelt wurden. Monatsberichte der Könglich Preussischen Akademie der Wissenschaften zu Berlin 1878: 524-550.

Sumida, P.Y.G., F.C. De Leo, and A.F. Bernardino. 2020. An introduction to the Brazilian deep-Sea biodiversity. In P.Y.G. Sumida, F.C. De Leo, and A.F. Bernardino (editors), Brazilian deep-sea biodiversity: 1-5. Cham, Switzerland: Springer

Taylor, M.C., and C.N. Roterman. 2017. Invertebrate population genetics across Earth's largest habitat: the deep-sea floor. Molecular Ecology 26: 48724896.

Traldi, E.S., and E. Schlenz. 1990. Estratégias de ocupação de um costão rochoso por cinco espécies de anêmonas do litoral sul do Estado de São Paulo. Academia Brasileira de Ciências, II Simpósio de Ecossistemas da Costa Sul e Sudeste Brasileira: estrutura, função e manejo 3: 67-74. Águas de Lindóia: Academia de Ciências do Estado de São Paulo Press.

Turra, A., et al. 2016. South Atlantic Ocean. First global integrated marine assessment. In L. Inniss and A, Simcock (editors), The first global integrated marine assessment, world ocean assessment I: 595-614. Cambridge: Cambridge University Press.

Uchida, H. 2007. Actinologia Japonica (2). On the Actiniarian family Actinernidae from Japan. Kuroshio Biosphere 3: 17-32.

Vanreusel, A., et al. 2010. The contribution of deep-sea macrohabitat heterogeneity to global nematode diversity. Marine Ecology - An Evolutionary Perspective 31: 6-20.

Verrill, A.E. 1864. Revision of the Polypi of the eastern coast of the United States. Memoirs of the Boston Society of Natural History 1: 1-45.

Verrill, A.E. 1866. On the polyps and echinoderms of New England, with descriptions of new species. Proceedings of the Boston Society of Natural History $10: 333-357$.
Verrill, A.E. 1869a. Review of the corals and polyps of the west coast of America. Transactions of the Connecticut Academy of Arts and Sciences 1: 377-558.

Verrill, A.E. 1869b. Synopsis of the polyps and corals of the North Pacific Exploring Expedition, under Commodore C. Ringgold and Capt. John Rodgers, U.S.N., from 1853 to 1856 . Collected by Dr. Wm. Stimpson, naturalist to the expedition. Part IV. Actiniaria [Second part]. Proceedings of the Essex Institute 6: 51-104.

Verrill, A.E. 1879. Notice of recent additions to the marine fauna of the eastern coast of North America, no. 5. American Journal of Science and Arts 17: 472-474.

Verrill, A.E. 1882. Notice of the remarkable marine fauna occupying the outer banks off the southern coast of New England, no. 4. American Journal of Science 23: 216-225.

Verrill, A.E. 1883. Reports on the Anthozoa, and on some additional species dredged by the "Blake" in 1877-1879, and by the U. S. Fish Commission Steamer "Fish Hawk" in 1880-82. Bulletin of the Museum of Comparative Zoology (Harvard University): 11, 1-72.

Verrill, A.E. 1899. Descriptions of imperfectly known and new actinians, with critical notes on other species, III. American Journal of Science and Arts 7: 143-146.

Verrill, A.E. 1900. Additions to the Anthozoa and Hydrozoa of the Bermudas. Anthozoa. Transactions of the Connecticut Academy of Arts and Sciences 10: $551-572$.

Wassilieff, A. 1908. Japanische Actinien. Abhandlungen des Mathematischen-Physikalischen Institutes der Kaiserlichen Bayerischen Akademie der Wissenschaften 1: 1-49.

Watling, L., J. Guinotte, M.R. Clark, and C.R. Smith. 2013. A proposed biogeography of the deep ocean floor. Progress in Oceanography 111: 91-112.

Watzl, O. 1922. Die Actiniarien der Bahamainseln. Arkiv für Zoologi 14: 1-89.

Weinland, D.F. 1860. Über Inselbildung durch Korallen und Mangrovebüsche im mexikanischen Golf. Württembergische Naturwissenschaftliche Jahreshefte 16: 31-44.

Widersten, B. 1976. Ceriantharia, Zoanthidae, Corallimorpharia, and Actiniaria from the continental shelf and slope off the eastern coast of the United States. Fishery Bulletin 74 (4): 857-878. 
Wilson, H.V. 1890. On a new actinia, Hoplophoria coralligens. Studies at the Biological Laboratory of the Johns Hopkins University 4: 379-387.

Wüst, G. 1964. The major deep-sea expeditions and research vessels 1873-1960: A contribution to the history of oceanography. Progress in Oceanography 2: 1-52.

Zamponi, M.O., M.J.C. Belém, E. Schlenz, and F.H. Acuña. 1998. Distribution and some ecological aspects of Corallimorpharia and Actiniaria from shallow waters of the South American Atlantic coasts. Physis 55: 31-45.

Zelnio, K.A., E. Rodríguez, and M. Daly. 2009. Hexacorals (Anthozoa: Actiniaria, Zoanthidea) from hydrothermal vents in the south-western Pacific. Marine Biology Research 5: 547-571.

Zhiubikas, I.I. 1977. Some species of actinians of the western region of the Barents Sea and Franz Josef Land. Biocoenoses of the shelf of Franz Josef Land and the fauna of adjacent waters: 106-125. St. Petersburg: Academy of Sciences of the U.S.S.R. Zoological Institute. 





\title{
SCientific Publications of the American Museum of Natural History
}

AMERICAN MUSEUM NOVITATES

BULLETIN OF THE AMERICAN MUSEUM of NATURAL HISTORY

Anthropological Papers of the american Museum of Natural History

\author{
Publications Committee \\ ROBERT S. VOSS, CHAIR \\ BOARD OF EDITORS \\ JiN MENG, PALEONTOLOGY \\ LORENZO PRENDINI, INVERTEBRATE ZOOLOGY \\ ROBERT S. VOSS, VERTEBRATE ZOOLOGY \\ Peter M. Whiteley, Anthropology \\ MANAGING EDITOR \\ MARY KNIGHT
}

Submission procedures can be found at http://research.amnh.org/scipubs

All issues of Novitates and Bulletin are available on the web (http://digitallibrary.amnh. org/dspace). Order printed copies on the web from:

http://shop.amnh.org/a701/shop-by-category/books/scientific-publications.html

or via standard mail from:

American Museum of Natural History-Scientific Publications

Central Park West at 79th Street

New York, NY 10024

(2) This paper meets the requirements of ANSI/NISO Z39.48-1992 (permanence of paper).

ON the Cover: A SPeCimen of the Genus Phelliactis from the DeEP SEA OF THE GULF of MEXICO. IMAGE COURTESY OF THE NOAA OfFICE OF Ocean Exploration and Research, DeEp Slope 2007. 